\title{
REFORMA PSIQUIÁTRICA NA REGIÃO OESTE DO PARANÁ: O DISCURSO DOS ENFERMEIROS E SUAS PRÁTICAS
}

Tese apresentada à Escola de Enfermagem da Universidade de São Paulo para obtenção do título de Doutor em Enfermagem.

Área de Concentração: Enfermagem Psiquiátrica

Orientadora: Prof $\stackrel{a}{D} r^{a}$. Ana Lúcia Machado

São Paulo

2008 
Nome: Terezinha Alves Dias

Título Reforma psiquiátrica na região oeste do Paraná: O discurso dos enfermeiros e suas práticas.

Tese apresentada à Escola de Enfermagem da Universidade de São Paulo para obtenção do título de Doutor em Enfermagem.

Aprovada em:

\section{Banca Examinadora}

Prof. Dr.

Instituição:

Julgamento:

Assinatura:

Prof. Dr.

Instituição:

Julgamento:

Assinatura:

Prof. Dr.

Instituição:

Julgamento:

Assinatura:

Prof. Dr.

Instituição:

Julgamento:

Assinatura: 


\section{DEDICATÓRIA}

Aos que reconhecem o direito de cidadãos de todas as pessoas, aos que fazem de sua prática profissional um meio para o desenvolvimento das potencialidades do ser humano, em especial aos profissionais de Saúde Mental da região oeste do Paraná.

À Maria Oliveira Dias, minha mãe, que sempre foi capaz de dar muito mais do que a vida lhe deu! Para ela, dedicarei sempre o que de melhor conseguir fazer, na certeza de que ela faria o melhor no meu lugar.

Ao meu pai (in memoriam), José Joaquim Alves Dias, apesar do pouco tempo de convivência, deixou o legado dos valores da vida: respeito, amor, responsabilidade e dignidade no sofrimento. Saudade eterna e lembranças bem-vindas!

À amiga Marister Piccoli (in memoriam), com quem compartilhei os anseios desse dia, mas que a vida a chamou antes. 


\section{AGRADECIMENTOS}

A Deus, pela Vida, Fé e Amizades, que acredito serem nossos maiores bens.

À professora Ana Lúcia Machado, pelas orientações e janelas abertas nesta trajetória, pelo seu incentivo e pela sua compreensão.

Aos professores Fernando Lefèvre e Ana Maria Lefèvre, pela atenção e apoio.

Aos professores e funcionários da Escola de Enfermagem de São Paulo.

Aos colegas da Universidade Estadual do Oeste do Paraná, pelo companheirismo e incentivo.

Aos meus familiares, em especial às irmãs Cida, Lúcia e família pelo apoio e incentivo.

Ao professor e amigo Jacó Fernando Schneider, meu primeiro orientador na área da Saúde Mental.

Às amigas Adriana Machado Covino e Rosângela Kátia.

A todos os integrantes do Grupo da Subjetividade.

À professora Neide Tiemi Murofuse, pela amizade e incentivo.

À amiga Elizabeth Braz, com quem compartilhei os melhores e piores momentos dessa trajetória, o apoio e a amizade serão lembranças eternas. 


\section{RESUMO}

Alves DT. Reforma psiquiátrica na região oeste do Paraná: o discurso dos enfermeiros e suas práticas. [tese]. São Paulo: Escola de Enfermagem, Universidade de São Paulo; 2008.

A Reforma Psiquiátrica é um processo de transformações que vem inquietando os profissionais da área da Saúde e alguns seguimentos da sociedade. Isto porque, as transformações paradigmáticas que estão ocorrendo no campo da saúde mental pressupõem a presença de profissionais com uma postura inovadora e criativa para desenvolverem no cotidiano práticas que concretizem a proposta de desinstitucionalização. No Paraná, continua sendo um desafio: para as universidades, o desafio é a formação de profissionais com uma concepção do novo paradigma que se comprometam com o processo; para os gestores, o entendimento do processo priorizando ações de assistência à saúde mental e, para os profissionais, a tenacidade em insistir na efetivação, apesar das adversidades. $\mathrm{Na}$ região oeste do Estado, a mobilização para implantar a reforma intensificou-se nos últimos cinco anos com o fechamento de um dos hospitais da região e a criação de novos dispositivos de atenção à saúde mental. Nesse contexto, os enfermeiros deparam-se com o desafio de refletir sobre seus conceitos e sua atuação profissional. O presente estudo buscou conhecer a concepção dos enfermeiros sobre o processo da Reforma Psiquiátrica e o seu cotidiano nesses serviços. Ao ser considerada a complexidade do momento, foram elencados dois objetivos: descrever a prática cotidiana dos enfermeiros nos serviços de assistência à saúde mental na região oeste do Estado do Paraná; relacionar e analisar a prática destes enfermeiros com as propostas da Reforma Psiquiátrica. Trata-se de uma pesquisa qualitativa com a estratégia metodológica do Discurso do Sujeito Coletivo. A investigação foi por meio de entrevista semi-estruturada, com treze enfermeiros, compreendendo a totalidade destes profissionais nos serviços de saúde mental da região no período de agosto de 2006 a janeiro de 2007. O conteúdo deu origem a 17 Discursos do Sujeito Coletivo, que apontaram para oito temas geradores de significações: qualidade de vida, envolvimento profissional/social, necessidade de mudanças na maneira de conduzir o processo, a estrutura da rede de atenção psicossocial, cuidado de enfermagem nos serviços de atenção psicossocial, a família e o processo terapêutico, recursos humanos na atenção psicossocial. Os discursos evidenciaram o acompanhamento crítico do processo da Reforma Psiquiátrica e convergiram com a idéia de que a proposta significa qualidade de vida para os pacientes. A prática cotidiana dos enfermeiros acontece essencialmente na sede do serviço e as ações desenvolvidas são: acolhimento, trabalho com grupos de pacientes e família, monitoramento de oficinas terapêuticas e orientações, sendo esta última a mais mencionada. Percebeu-se que, em concomitância com os esforços dos enfermeiros nas transformações dos serviços de saúde mental, ainda permeiam alguns argumentos próprios do modelo biomédico.

PALAVRAS-CHAVE: Reforma Psiquiátrica, Cotidiano e Enfermeiros. 


\begin{abstract}
Alves Dias T. The nurses participation in the process of the psychiatric reform in the West region of Paraná State . [thesis], São Paulo: School of Nursing, Universidade de São Paulo, 2008.

The Psychiatric Reformation is a process of transformations that worries the professionals of the health area and some segments of the society. The paradigmatic transformations that are occurring in the field of the mental health, estimate the presence of professionals with an innovative and creative position to develop daily practical activities that will perform the proposal the service not to be institutionalized. In Paraná it continues being a challenge: for the universities, the challenge is the formation of professionals with a conception of the new paradigm who will compromise to the process; for the managers, the agreement of the process prioritizing action of assistance to Mental Health and, for the professionals, the tenacity in insisting in making it effective, even though the adversities. In West region of the state, the mobilization to implant the reform was intensified in the last five years with the closing down of one of the hospitals of the region and the creation of new devices of attention to the mental health. In this context the nurses came across to the challenge to reflect on their concepts and their professional performance. The present study searched to know the conception of the nurses on the process of the psychiatric reform and their daily activities in these services. Considering the complexity of the moment, two objectives had been listed: to describe practical daily activities of the nurses in the services of assistance to the mental health in the West Region of the State of Paraná; to relate and analyze the practical activities of these nurses with the proposals of the psychiatric reform. This is a qualitative research with the methodological strategy of the Speech of the Collective Subject. The research was through half-structuralized interview, with thirteen nurses, understanding the totality of these professionals in the services of mental health of the region, in the period of August of 2006 the January of 2007. The content gave to origin the 17 Speeches of the Collective Subject that led to eight generating subjects of meanings: quality of life, social professional envolvement/, necessity of changes in the way to lead the process, the structure of net of the psicossocial, well-taken care of attention of nursing in the services of psicossocial attention, the family and the therapeutical process, human resources in the psicossocial attention. The speeches had evidenced the critical accompaniment of the process of the psychiatric reform and had converged with the idea that the proposal means quality of life for the patients. Practical daily activities of the nurses happens essentially in the headquarters of the service and the developed actions are: the shelter, the work with groups of patients and family, monitoring of therapeutical workshops and orientations, being the last one the most mentioned one. It was realized that in concurrence with the efforts of the nurses in the transformations of the services of mental health, still some proper arguments of the biomedical model are kept.
\end{abstract}

KEY-WORDS: The Psychiatric Reformation, Daily activities, Nurses. 


\section{LISTA DE QUADROS}

Quadro 1 - Instrumento de Análise de Discurso - Questão analisada: Como você vê a Reforma Psiquiátrica? 070

Quadro 2 - Categorias internas $1 \quad 071$

Quadro 3 - Categorias Internas $2 \quad 079$

Quadro 4 - Categorias Internas $3 \quad 092$

Quadro 5 - Categorias Internas 4 105 
LISTA DE ABREVATURAS E SIGLAS

$\begin{array}{ll}\text { AC } & \text { Ancoragem } \\ \text { Cais } & \text { Centro de Atividades Integradas em Saúde Mental } \\ \text { Caps } & \text { Centro de Atenção Psicossocial } \\ \text { CAPSi } & \text { Centro de Atenção Psicossocial Infantil } \\ \text { CASME } & \text { Centro de Atendimento à Saúde Mental } \\ \text { CEP } & \text { Comitê de Ética em Pesquisa } \\ \text { CNS } & \text { Conselho Nacional de Saúde } \\ \text { Conep } & \text { Comissão Nacional de Ética em Pesquisa } \\ \text { CRE } & \text { Centro Regional de Especialidades } \\ \text { DSC } & \text { Discurso do Sujeito Coletivo } \\ \text { ECH } & \text { Expressões-Chave } \\ \text { HD } & \text { hospital dia } \\ \text { IAD } & \text { Instrumento de Análise de Discurso } \\ \text { IC } & \text { Idéias Centrais } \\ \text { Naps } & \text { Núcleos de Atenção Psicossocial } \\ \text { UBS } & \text { Unidade Básica de Saúde } \\ \text { Unioeste } & \text { Universidade Estadual do Oeste do Paraná } \\ \text { UTFPR } & \text { Universidade Tecnológica Federal do Paraná }\end{array}$




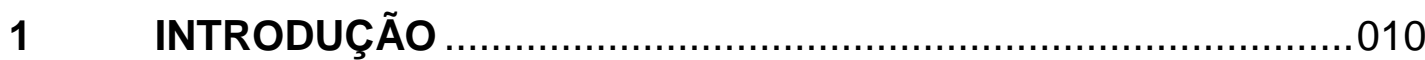

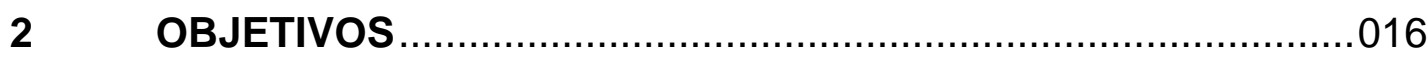

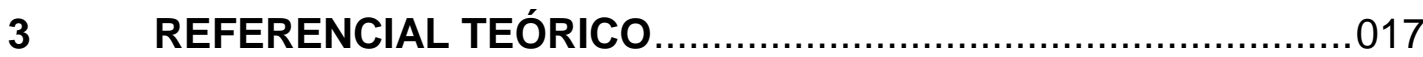

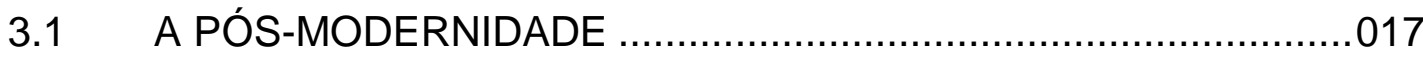

3.2 ASSISTÊNCIA PSIQUIÁTRICA - MODELOS

ANTECEDENTES À REFORMA PSIQUIÁTRICA ........................022

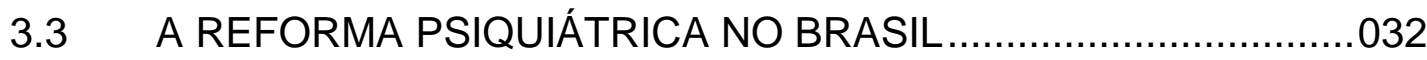

3.4 A REFORMA PSIQUIÁTRICA NO PARANÁ................................042

3.5 A ENFERMAGEM BRASILEIRA NO CONTEXTO DA REFORMA PSIQUIÁTRICA .....................................................046

3.6 COTIDIANO DOS ENFERMEIROS NOS SERVIÇOS

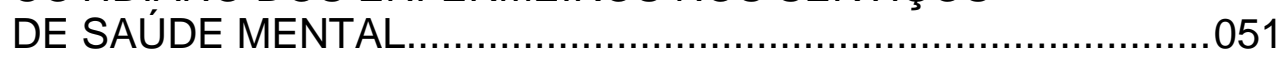

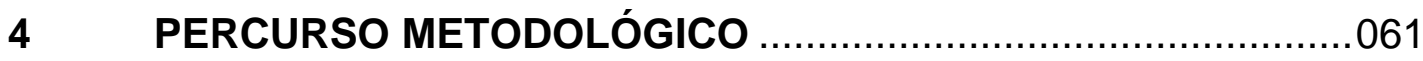

4.1 A PESQUISA QUALITATIVA …......................................................

4.2 A ESTRATÉGIA DO DISCURSO DO SUJEITO COLETIVO..........062

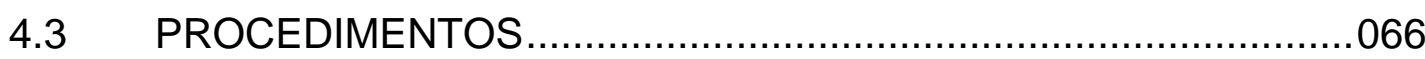

5 APRESENTAÇÃO DA PESQUISA DE CAMPO …..........................

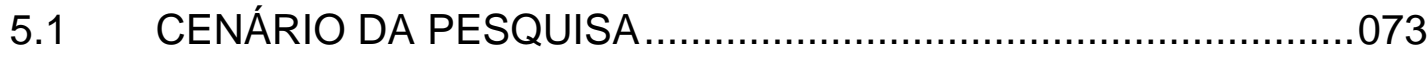

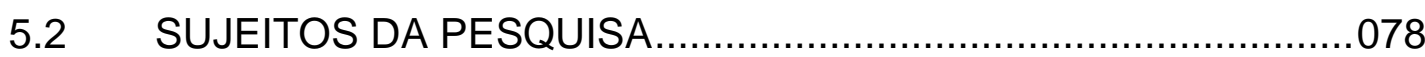

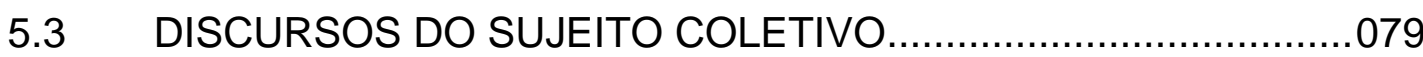

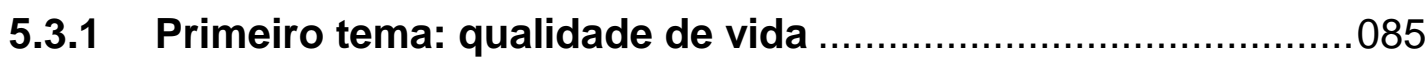

5.3.2 Segundo tema: envolvimento profissional / social ..................087

5.3.3 Terceiro tema: necessidade de mudanças na administração do processo ......................................................090

5.3.4 Primeiro tema: o enfermeiro na organização do serviço de saúde mental

5.3.5 Segundo tema: o cuidado de enfermagem nos serviços de atenção psicossocial.

5.3.6 Primeiro tema: a família e o processo terapêutico ...................110

5.3.7 Segundo tema: recursos humanos na atenção psicossocial... 113

5.3.8 Terceiro tema: a evolução dos pacientes ..............................117 CONSIDERAÇÕES FINAIS................................................................120

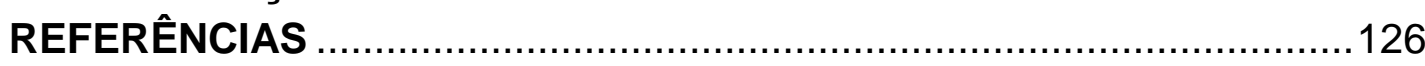

APÊNDICES

ANEXOS 


\section{INTRODUÇÃO}

"Entrar em um caminho de transformação não é estar à procura do fantástico ou do extraordinário, mas é aprender a fazer de maneira grande as coisas pequenas."

Jean-Yves Leloup

O presente trabalho é o resultado de um estudo realizado na região oeste do Estado do Paraná. Trata-se de uma investigação sobre a participação dos enfermeiros no processo da Reforma Psiquiátrica, a partir de seus depoimentos acerca da visão que eles têm das propostas da Reforma Psiquiátrica e suas práticas cotidianas nos serviços de assistência à saúde mental.

É uma pesquisa qualitativa orientada por uma visão de pósmodernidade, com enfoque no cotidiano e na sociedade, seguindo 0 referencial de Michel Maffesoli, sociólogo francês contemporâneo, cujas investigações enfatizam a constatação do crescimento de uma cultura dos sentimentos e uma tendência à substituição de um social racionalizado por uma socialidade com dominante empática (Maffesoli, 1998).

Inserida como docente, em um contexto de transição do modelo assistencial, no município de Cascavel, no Estado do Paraná, começaram minhas primeiras inquietações acerca da atuação do enfermeiro nesse processo.

Ao ministrar a disciplina de Enfermagem Psiquiátrica e em Saúde Mental, percebeu-se que, involuntariamente, a prática era ambígua. Ao mesmo tempo em que apresentava a história da psiquiatria, apontando a Reforma Psiquiátrica como um avanço, as aulas práticas forçosamente aconteciam em um hospital.

A ambigüidade estava no fato de o hospital ser do modelo hegemônico, com práticas predominantemente disciplinadoras e medicamentosas, enquanto o ensino era orientado pelo modelo psicossocial em implantação. Contudo, esse hospital era a única instituição a prestar assistência psiquiátrica na cidade. 
Como agente terapêutico, os enfermeiros devem tomar medidas que ajudem o indivíduo na execução de atividades que contribuam para a manutenção da saúde ou para sua recuperação, bem como prepará-lo para se tornar independente desta ajuda. Mas os poucos que trabalhavam no hospital desempenhavam apenas as ações pautadas nas ordens médicas.

Esse quadro trouxe preocupação em relação às atividades de ensino, principalmente quando os alunos questionavam: "O que o enfermeiro faz no serviço de saúde mental?" Muito embora nas aulas teóricas já tivessem sido exaustivamente discutidos o espaço do enfermeiro e as suas atividades, tal questionamento surgia por não ser visualizada a sua atuação. $O$ perfil profissional observado não correspondia àquele descrito e discutido nas aulas teóricas.

Ao perceber a necessidade de ampliar as discussões com os alunos e colegas sobre os aspectos que envolvem as ações dos enfermeiros nesse contexto de reforma, foram intensificados o estudo e a divulgação de trabalhos sobre os serviços de assistência à saúde mental que estavam se transformando (Medeiros, 1977; Nicácio 1994; Moreno, 1995; Aguiar, 1995) e que começavam a se orientar por um novo modelo. Dessa forma, direcionou-se parte das aulas práticas para a comunidade.

Também houve participação nas reuniões do Conselho Municipal de Saúde e nas reuniões com a Secretaria Municipal de Saúde, que, apesar de ter um projeto de reestruturação da assistência em saúde mental desde 1995, ainda não tinha avançado. O município contava apenas com o referido hospital psiquiátrico, um Centro de Atenção Psicossocial Infantil (Capsi) e um ambulatório no Centro Regional de Especialidades (CRE).

No segundo semestre de 2002, o hospital desenvolveu um projetopiloto de Hospital Dia (HD). Trabalhou com 16 pacientes residentes no município e, considerando viável a sua implantação, em 2003 apresentou a proposta para a Secretaria de Saúde. Entretanto, o Conselho Municipal de Saúde não a aprovou, entendendo que esse serviço não deveria estar vinculado ao setor privado e exigiu que o município tomasse as iniciativas de implementação e criação dos serviços de assistência em saúde mental. 
Diante da não-aprovação do projeto para a instalação do HD pelo Conselho Municipal de Saúde, proprietários e diretores do hospital optaram pelo seu fechamento, encerrando suas atividades no prazo mínimo exigido pela legislação.

O fechamento dessa instituição em 3 de novembro de 2003 fez acelerar o processo de criação de serviços previsto no plano de atenção à saúde mental, o qual vinha seguindo um cronograma que se estenderia até o final do ano de 2005. Nessas circunstâncias, o município precisou agilizar algumas ações.

Nesse hospital concentrava-se a maior parte da assistência aos pacientes, não só da cidade como também da região, com 350 leitos destinados ao atendimento de doentes mentais, dependentes químicos de ambos os sexos, sendo referência de assistência psiquiátrica na região há mais de 25 anos.

Havia uma equipe composta por seis psiquiatras, dois clínicos, quatro assistentes sociais, quatro psicólogas, seis enfermeiras, um professor de educação física, 32 auxiliares de enfermagem, dois terapeutas ocupacionais, quatro monitores (horta, marcenaria e trabalhos manuais), além dos funcionários dos serviços de apoio e administrativo. Em sua maioria, as auxiliares de enfermagem, assistentes sociais e psicólogas estavam na instituição por período superior há cinco anos, muitos deles já com vinte anos.

O processo de fechamento do hospital gerou um estado de ansiedade e preocupação aos familiares e aos próprios pacientes, em vista de não terem sido preparados para a nova situação. Percebe-se também que as equipes de saúde geral, em especial as da Unidade Básica de Saúde (UBS) e serviços de emergência da cidade e da região, não se sentiam preparadas nem compromissadas com a assistência a esses pacientes.

O primeiro passo foi criar uma equipe responsável para agilizar o processo de reestruturação da Assistência em Saúde Mental no município, em especial solucionar o problema dos internos, sendo uma enfermeira a responsável por essa equipe. Na última quinzena de funcionamento do hospital, ainda havia 201 pacientes internados. 
Foi realizado um acompanhamento da avaliação médica dos pacientes internados para averiguar quantos tinham necessidade de permanecer hospitalizados e quais deles teriam possibilidades de continuar o tratamento ambulatorial. Os impossibilitados de receberem alta foram transferidos para outro hospital da região, após informação aos familiares e consentimento destes.

Porém, a complexidade maior estava no atendimento aos moradores, pois 16 pessoas já haviam perdido vínculos com os familiares e a sociedade. Mas após discussão envolvendo assistentes sociais da instituição, com a Secretaria Municipal de Saúde e os coordenadores de instituições nãogovernamentais, estas últimas acolheram as pessoas, contando com suporte financeiro e assistencial da Secretaria de Saúde, por período indeterminado, até que as residências terapêuticas fossem organizadas. $O$ primeiro serviço instalado nessa fase foi o Centro de Atendimento à Saúde Mental (Casme).

A realidade local chamou-nos a atenção para um problema já conhecido: a inadequação dos recursos humanos disponíveis como obstáculos para se efetivarem as propostas da Reforma Psiquiátrica. A coordenadora da equipe de saúde mental municipal organizou o I Curso de Formação em Saúde Mental com ênfase em reabilitação psicossocial, para as equipes das Unidades Básicas de Saúde (agentes comunitários de saúde e auxiliares de enfermagem e, posteriormente, para enfermeiros, psicólogos, assistentes sociais e médicos), no qual minha participação foi como instrutora.

O objetivo desse curso foi instrumentalizar as equipes para a assistência nesse novo modelo, pois a transformação não se passa somente na troca do modelo, mas, principalmente, na transformação da atuação dos profissionais envolvidos com a questão da saúde mental.

Diante dessa situação, as aulas práticas foram todas deslocadas para a comunidade, não só em grupos reunidos pelo docente e nas famílias, mas, principalmente, nas Unidades Básicas de Saúde (UBSs).

A Reforma na Assistência em Saúde Mental do município tornou-se uma realidade incontestável. Mas, sabe-se que o fim dos manicômios por si só não significa uma assistência melhor ao paciente. 
Acolher as pessoas acometidas pela doença mental é uma das atividades que os enfermeiros das UBSs passam a desenvolver, é um exercício novo para eles, que exige uma busca de suportes técnicos e científicos para uma função em conjunto com outros profissionais de saúde mental, como agente terapêutico (Telles, 2002).

Diante desse quadro, permeado de conceitos contraditórios e incertezas, os questionamentos impulsionaram a busca por identificar e entender o que o enfermeiro faz no seu cotidiano. Nesse sentido, foi dado o início ao Doutorado em 2005, o qual trouxe como objeto de estudo a participação dos enfermeiros no processo de Reforma Psiquiátrica.

O projeto era amplo, objetivando estudar o cotidiano dos enfermeiros nos serviços de saúde mental do Estado do Paraná. O estudo seria uma investigação sobre as atividades desenvolvidas por eles, a visão que tinham da Reforma Psiquiátrica e a compreensão e expectativas dos enfermeiros envolvidos com esse novo modelo. Posteriormente, far-se-ia uma análise dos dados à luz dos pressupostos da Reforma Psiquiátrica.

O objeto de estudo estava definido, mas havia também a pretensão de fazer uma pesquisa de modo diferente das que conhecia, havia a curiosidade de aprender outro modo de apresentar um trabalho científico, que evidenciasse, também, o saber dos sujeitos do estudo de maneira pura e não somente a interpretação sobre esse saber.

Nessa busca, houve o interesse pela disciplina do professor Fernando Lefèvre sobre uma proposta metodológica que apresenta uma estratégia de organização e apresentação dos dados, em que as falas dos sujeitos individuais são transformadas em discursos entrelaçados incluídos no corpo do trabalho sob a forma de um discurso: o "Discurso do Sujeito Coletivo". Após conclusão dessa disciplina e discussão com o professor e orientadora, optou-se por esse método de análise na pesquisa proposta.

A participação no Grupo de Pesquisa da Subjetividade em Saúde da Escola de Enfermagem da Universidade de São Paulo possibilitou uma discussão mais analítica, que determinou um redirecionamento do estudo, o qual foi centrado na região oeste do Estado do Paraná, região em que estou inserida como pessoa e profissional. 
No grupo também houve uma aproximação maior com estudos focados nas características da pós-modernidade da Sociologia Compreensiva. Em decorrência dessas experiências, o resultado foi um projeto de Pesquisa Qualitativa - com a estratégia metodológica do Discurso do Sujeito Coletivo, numa visão de pós-modernidade.

Nessa orientação, o estudo foi desenvolvido e se apresenta da seguinte forma: objetivos, uma abordagem sobre o contexto da pósmodernidade e uma releitura sobre a Assistência Psiquiátrica - Modelos Antecedentes à Reforma, a Reforma Psiquiátrica no Brasil e no Paraná, a Enfermagem no Contexto da Reforma Psiquiátrica e o Cotidiano dos Enfermeiros nos Serviços de Saúde Mental.

A seguir, tratou-se do percurso metodológico, com uma explanação da Pesquisa Qualitativa e apresentação da estratégia metodológica do Discurso do Sujeito Coletivo (DSC), empregado na organização do conteúdo das entrevistas.

Prosseguindo, apresentou-se a pesquisa de campo em três etapas:

1를 Cenário da pesquisa.

$2^{\text {a }}$ Sujeitos da pesquisa.

$3^{a}$ Discursos do Sujeito Coletivo - Apresentação e discussão dos temas geradores de significâncias.

Com as considerações aqui feitas, pôde-se pontuar a experiência no desenvolvimento desta pesquisa com a certeza de que não se esgotou o estudo do tema, mas também ficou-se ciente da importância deste estudo como material disponibilizado para reflexão e conhecimento deste momento histórico da Assistência em Saúde Mental nesta região. Nele estão: a percepção, o saber e as condutas de uma equipe que, mesmo com todas as adversidades, está empenhada em efetivar a Reforma Psiquiátrica. 


\section{OBJETIVOS}

Considerando o momento de implantação da Reforma Psiquiátrica e sua complexidade, foram elencados para esta pesquisa dois objetivos que retratarão parte da história do processo na região oeste do Paraná.

a) Descrever a prática cotidiana dos enfermeiros nos serviços de Assistência à Saúde Mental na região oeste do Estado do Paraná.

b) Relacionar e analisar a prática desses enfermeiros com as propostas da Reforma Psiquiátrica. 


\title{
3 REFERENCIAL TEÓRICO
}

\subsection{A PÓS-MODERNIDADE}

\author{
"A vida vem em ondas \\ Como um mar \\ Num indo e vindo infinito \\ Tudo que se vê não é \\ Igual ao que a gente viu \\ Há um segundo \\ Tudo muda o tempo todo no mundo \\ Não adianta fugir, nem mentir para si mesmo \\ Zlgora \\ Há tanta vida lá fora \\ Alqui dentro sempre!"
}

Nelson Mota e Lulu Santos

A abordagem da pós-modernidade neste estudo é no sentido de evidenciar que a compreensão e a atenção dispensadas à saúde mental acompanham o contexto histórico e estão articuladas com saberes que não se restringem à área da saúde mental.

Aqui foram pontuados três aspectos da pós-modernidade identificados como passivos de atenção para a compreensão do contexto vivenciado pelos sujeitos do estudo, a saber:

- A transitoriedade: É o movimento e a presença simultânea de conceitos e produtos em que acontecem conflitos, mas que não se anulam e o novo não substitui o velho, mas convive com a fragilidade de conceitos e o questionamento à ciência. Este item foi elencado porque a Assistência à Saúde Mental, atualmente, tem uma proposta legalmente aprovada e racionalmente aceita, mas, no cotidiano, esbarra em atitudes e posturas elaboradas em conceitos arcaicos.

- A subjetividade: É um elemento reconhecido na pós-modernidade como determinante dos modos de existência, pois modela as maneiras de sentir e pensar. É produzida no social e considerada pela saúde mental relevante para as relações interpessoais e terapêuticas. 
- A globalização: É entendida como o processo de aproximação de grupos sociais de culturas diferentes, o que ocorre com mais intensidade e freqüência na região deste estudo devido às características sociogeográficas.

Essa abordagem pode ser precedida por um apontamento das características que marcaram a modernidade, para a percepção das mudanças que ocorreram e que estão ocorrendo em todas as áreas.

No período pré-moderno, o homem estava voltado ao sobrenatural, ao espírito, e os fenômenos eram explicados pelos saberes e poderes transcendentais ou simplesmente aceitos. A loucura era um fenômeno sobrenatural, que fazia a pessoa acometida por ela ser diferente das outras, mas não inferior; ela concedia uma posição de destaque.

$\mathrm{Na}$ modernidade, o marco foi $\mathrm{o}$ avanço das ciências e um distanciamento de tudo que não fosse possível comprovar objetivamente. $O$ avanço tecnológico que impulsionou a revolução industrial contribuiu para consolidar o paradigma científico do Positivismo, paradigma que Santos (1996) define como técnico, que atendeu às perspectivas do capitalismo e estimulou a produção de riquezas. A razão e a capacidade de produção foram muito valorizadas.

Descartes foi um dos responsáveis pelos construtos filosóficos do universo da razão e pela expulsão simbólica do universo da desrazão. Da sua racionalidade, originou-se a ruptura entre o mundo do corpo e o do espírito, ou seja, entre o objeto e o sujeito. Quando escreveu “...das coisas que se podem colocar em dúvidas...", norteou-se pela busca das coisas verdadeiras (Foucault, 1978).

O corpo passou a ser objeto de estudo da ciência e o espírito objeto apenas da filosofia, estabelecendo com isso também a ruptura da ciência com a filosofia, que significou um marco na tradição ocidental, interferindo negativamente no avanço dos estudos humanísticos (históricos, jurídicos, literários, filosóficos e teológicos) e dificultando o reconhecimento destes, como saberes paradigmáticos (Santos, 1996).

A concepção da racionalidade baniu dos espaços públicos o louco, porque a desrazão o tornava improdutivo e inadequado, significando risco à 
ordem social e perigo à sua segurança. Tal fato deu propulsão à construção dos manicômios e às ações de segregação que ainda permeiam o campo da saúde mental.

Ao falar da era contemporânea, da pós-modernidade, não se tem registros de quando ela começou. Para Spink (2004), não há como defender filosoficamente essa tese nem justificá-la empiricamente se ela significa uma ruptura ou se é continuidade da era moderna, a qual denomina de modernidade tardia. Mas é possível delinear as características próprias de ambos os períodos.

A diferença mais evidente entre os dois períodos - a modernidade e a pós-modernidade - é que enquanto a modernidade se caracterizou pela afirmação positivista e totalitária, a pós-modernidade está no movimento de desmistificação da ciência por meio de questionamentos. "A ciência pósmoderna sabe que nenhuma forma de conhecimento é em si mesma, racional; só a configuração de todas elas é racional." (Santos, 1989 p.55).

Maffesoli (1998), em sua visão de mundo, registra os movimentos sociais com suas transformações, percebendo uma postura diferente na maneira de expressão social do homem, identificando o desenvolvimento de microgrupos a que ele chama de tribos, por entender que essa metáfora possibilita dar conta do processo de individualização da saturação da função que lhe é inerente e da valorização do papel que cada pessoa (persona) é chamada a representar dentro dela.

Segundo Maffesoli, a modernidade tinha uma convivência social caracterizada por uma estrutura mecânica, com organização centrada no econômico, onde os indivíduos tinham função a desempenhar no interior de grupos contratuais, já na pós-modernidade, apresenta-se como uma estrutura complexa ou orgânica, com a concentração das massas em que as pessoas desempenham papéis em tribos afetuais, sendo esse convívio denominado socialidade (Maffesoli, 1998).

Uma das características da pessoa na pós-modernidade é sua desenvoltura em transitar por diferentes tribos, conviver com a herança cultural do positivismo, que ainda predomina nas organizações sociais, mas, ao mesmo tempo, abre espaço para os questionamentos contemporâneos e 
admite incertezas; nesse particular conturbado, constrói sua subjetividade, que "...ao longo de toda modernidade, constantemente foi deliberadamente afastada da progressão científica.” (Maffesoli, 2005, p. 141).

A subjetividade, no contexto da modernidade, aparecia como fonte de erros, algo a ser eliminado por completo. Com isso, expulsou-se o sujeito da história, eliminaram-se as decisões, as personalidades, para só ver determinismos sociais, estruturas. Com o olhar de Foucault e Barthes, o sujeito volta a ser evidenciado quando se encontra novamente problematizado (Morin, 2006).

A subjetividade na perspectiva filosófica é definida por Machado e Colvero (2003, p. 52) como:

...caráter de todos os fenômenos psíquicos, enquanto fenômenos de consciência, que o sujeito relaciona consigo mesmo e chama de meus. Também do caráter do que é subjetivo, no sentido de ser aparente, ilusório ou falível.

A globalização, que é um fenômeno que vem ocorrendo na atualidade, favorecido por uma tecnologia que em pouco tempo dissemina a cultura e as descobertas, vem sendo tema de muitos estudos contemporâneos: a globalização e as ciências sociais (Santos, 2002), cultura global (Appadurai, 1990; Robertson, 1992) sistema global (Sklair, 1991) e processo global (Friedman, 1995) entre outros.

Para Santos (2002, p. 63), a produção de globalização é:

o conjunto de trocas desiguais pelo qual um determinado artefato, condição, entidade ou identidade local estende a sua influência para além das fronteiras nacionais e, ao fazê-lo, desenvolve a capacidade de designar como local outro artefacto, condição, entidade ou identidade rival.

Esse fenômeno tem influenciado o processo de subjetividade, na medida em que afeta as identidades locais fixas, tornando-as flexíveis, mudando ao sabor dos movimentos do mercado e com a mesma velocidade. Com isso, a globalização causa uma desestabilização exacerbada, confrontando com a persistência da referência identitária, uma percepção de esvaziamento da própria subjetividade, despersonalização que pode conduzir ao enlouquecimento (Rolnick, 1997). 
A pós-modernidade apresenta um cenário de múltiplas possibilidades, e isso faz com que tudo seja avaliado constantemente, sendo complementado, trocado ou, simplesmente, descartado. Essa oscilação acontece em toda a esfera social, já que, a cada momento, há novas descobertas, novos conhecimentos e novas informações, atuando de forma a mudar a vida cotidiana. Porém, estas mudanças nem sempre são enriquecedoras, pois envolvem perdas:

...uma fragmentação simbólica advém da insustentabilidade desse processo, da perda de valores culturais que dão referência à construção de subjetividades. A importação de modelos globais, em todas as dimensões da vida humana, pulveriza a dimensão simbólica, de forma violenta, transformando os modos de produção, de hábitos, de valores, e outros, promovendo um desenraizamento cultural, gerando um mundo de incertezas e de riscos produzidos, o qual se desdobra na perda da liberdade e da identidade humana (Andrade, Bosi, 2003, p. 3).

A aproximação de grupos sociais de culturas diferentes, apesar dos riscos, enriquece a experiência de vida e as torrentes de informações nos mantêm o tempo todo em estado de alerta, de vivacidade. Os enfermeiros sujeitos deste estudo vivenciam em sua vida profissional um momento de transição, marcado pela implantação do novo modelo assistencial, em meio a uma sociedade com fortes resquícios de conceitos e crenças sobre a assistência psiquiátrica sedimentados ao longo dos tempos.

Esse quadro é vivenciado com mais intensidade pelos sujeitos entrevistados, pois estão inseridos em uma região habitada por brasileiros - paranaenses de diversas origens. Há, ainda, a presença de tribos indígenas, uma população significativa de muçulmanos e outras nacionalidades orientais, como os coreanos. Além disso, é uma região com fronteiras internacionais (Paraguai e Argentina) e abriga um dos pontos turísticos mais visitados do mundo, as Cataratas do Iguaçu. Forçosamente, esses profissionais convivem com muitas diferenças, cuja cultura contrasta com a da sua própria origem e formação profissional.

A convivência com o arcaico e o novo provoca uma constante busca de equilíbrios interno e social, uma combinação bastante cultural originária de uma experiência em comum, de uma série de ajustamentos 
que, de algum modo, constituíram uma espécie de equilíbrio a partir de elementos heterogêneos, de certa forma, uma harmonia conflituosa (Maffesoli, 1998).

No entanto, não se pode negar que, junto com uma efemeridade aparente, há intensidade nas experiências vividas. Na pós-modernidade vigora a ética das situações, uma ética atenta à paixão, à emoção, em uma palavra, aos afetos de que estão impregnados os fenômenos humanos (Maffesoli, 2001). A vida social, em sua integralidade, está imersa em uma atmosfera estética, é feita cada vez mais de emoções, sentimentos e afetos compartilhados (Maffesoli, 2005).

\subsection{ASSISTÊNCIA PSIQUIÁTRICA - MODELOS ANTECEDENTES À REFORMA PSIQUIÁTRICA}

O Modelo de Assistência Psiquiátrica é aqui entendido como um conjunto de medidas práticas preconizadas para a assistência às pessoas com transtornos mentais, que são pautados em valores culturais, em crenças e no saber científico. É a relação cambiente e tensa entre o político e o técnico e que contempla, a partir das necessidades sociais, diretrizes políticas e referenciais teóricos, além dos modos de gestão (Campos, 1992). De maneira geral, é a compreensão do fenômeno pela sociedade que tem norteado a relação com as pessoas que apresentam conduta social inadequada, definida pela maioria, desde os primórdios, como "loucas".

Não é objetivo do presente estudo explorar a história da loucura, mas resgatar a visão que a sociedade direcionou a ela ao longo dos tempos e que contribuiu para a construção dos modelos assistenciais. O reporte parte das obras de Foucault, em especial a História da Loucura, obra considerada fundamental para o estudo da psiquiatria e das práticas médicas de intervenção da loucura (Amarante, 1995). 
Foucault faz uma descrição de como a loucura era entendida e tolerada em diferentes épocas, mas não considera como evolução do conhecimento da loucura os diferentes conceitos que têm surgido, pois eles Ihe parecem ora complementares, ora contraditórios, induzindo diferentes formas de lidar com a loucura (Foucault, 1978).

Na época do Renascimento, a loucura não era motivo para exclusão de seus portadores nem significava uma ameaça à segurança da sociedade. Reconhecida como uma experiência positiva, não era apenas tolerada, mas também exaltada. Ela era relacionada à presença de transcendências imaginárias e, quando presente, tornava a pessoa uma figura diferenciada, mas não inferior ou deficiente em relação às outras (Foucault, 1978). Assim sendo, concedia uma posição de destaque e as pessoas loucas viviam livremente em meio às outras.

Na Idade Clássica - século XVII, quando o pensamento cartesiano passa a dominar o mundo com a desvalorização de tudo que não apresentasse exatidão e objetividade -, a loucura passa a não ser mais relacionada à sabedoria, mas sim à desrazão e, portanto, sua experiência era ausente de significado.

Duas concepções distintas sobre a loucura são apresentadas por Foucault (1978) e, de alguma maneira, determinariam a forma de vida das pessoas acometidas por ela. A concepção da época do Renascimento, como constitutiva, descrita anteriormente, era inscrita no universo de diferença simbólica e reconhecida como enunciadora da verdade. A outra que surgiu na Idade Clássica, com o pensamento cartesiano, é a concepção crítica, que nega qualquer poder de revelação e enunciação da verdade, além de organizar um lugar de encarceramento e exclusão para o louco.

Sob a influência dessa nova concepção sobre a loucura foram criadas as casas de internação. Nos contextos político e social, cuja ênfase estava na produção de riquezas, a loucura representava a incapacidade para o trabalho e, portanto, um problema social.

Essas casas eram uma espécie de hospedaria e não abrigavam apenas os loucos, mas também libertinos, prostitutas, ladrões e criminosos, enfim todos os que atentavam contra a ordem social. Elas não tinham função 
terapêutica, apenas garantiam a segurança, isolando do meio social todos os que não poderiam contribuir para o seu enriquecimento, fossem estes libertinos ou incapazes. Portanto, a visão da loucura era a mesma das outras categorias marginais, tendo como critério de exclusão e enclausuramento a desrazão. A ausência de razão não estava relacionada à área patológica nem a cuidados médicos.

A percepção social da loucura passa a ser representada, na Idade Média, pela ética do internamento e não se cruza com a elaboração de conhecimento sobre a loucura. Na Idade Clássica, o internamento era uma prática de proteção e guarda, como um jardim das espécies. Já o século XVIII é marcado pela convergência entre percepção, dedução e conhecimento e passa a ser um procedimento médico terapêutico (Amarante, 1995).

O louco sendo ainda reconhecido como risco e periculosidade para o meio social e agora também como doente, $\mathrm{O}$ internamento atendia a necessidade de proteção da sociedade e o tratamento do louco. A loucura passa a ser entendida como um estado de contradição da alma com perda parcial da razão. As casas de internação passaram à categoria de asilos e espaços da construção dos saberes e práticas psiquiátricas (Foucault, 1978).

A conduta de Philippe Pinel - médico francês em 1793 -, de concentrar os loucos em um espaço próprio, sem as correntes, foi decisivo na consolidação do Modelo Clássico Psiquiátrico. Na observação sistemática dos loucos, iniciou classificando as doenças mentais como distúrbio do autocontrole e da identidade, ao que denominou de alienação. Assim surgiu a Psiquiatria Clínica. O louco ganhou o "status" de doente e deveria ser protegido, controlado. A internação garantia um espaço de expressão da loucura sem que representasse perigo à sociedade e, ao mesmo tempo, incluía a possibilidade de tratamento (Amarante, 1995).

O fato de desacorrentar os alienados não significou liberdade, apenas o direito ao tratamento dentro do espaço da instituição. Desde o momento em que Pinel criou o espaço específico para as pessoas loucas, com o intuito de tratá-las e desenvolver o saber psiquiátrico, ele foi alvo de muitas críticas, tanto quanto de apoio como de contestação. As críticas de 
contestação tinham como principal alvo o sistema de clausura, a rigidez da autoridade na relação com os internos para manter a disciplina e adequá-los socialmente. Tais críticas culminaram por consolidar um primeiro modelo de reforma à tradição pineliana, ou seja, o das colônias de alienados (Amarante, 1995).

O modelo das colônias não se diferenciou muito do hospício tradicional e em relação ao princípio de liberdade, apenas ampliou o espaço que permaneceu limitado. Os pacientes continuaram presos, sem direito de saírem das colônias e impedidos de freqüentarem os espaços públicos.

No decorrer da história, houve várias reformulações dos modelos de assistência psiquiátrica, todos centrados no saber médico e de caráter institucionalista. A prática assistencial foi direcionada para os sinais e sintomas da loucura, sendo seu portador passivo de estudo, devendo ser observado e acompanhado, sendo imprescindível para o tratamento do alienado o isolamento, passando, então, a ser condição necessária para a restituição da liberdade da qual a loucura o privou (Foucault, 1978).

Segundo Castel (1978), as práticas alienistas consolidaram-se com a Lei $n^{\circ}$ 1.838, que regulamentou o regime dos alienados na França, influenciando em todo o mundo a relação com o louco. A referida Lei estabeleceu as diferenças entre o louco, o cidadão e o criminoso. O cidadão, indivíduo racional responsável por seus atos, obediente às leis e livre; o criminoso também racional e responsável, mas que transgrediu as leis, merecendo a exclusão da sociedade, a prisão; o louco, considerado desprovido de razão e incapaz para o convívio social e isento de responsabilidade, sendo digno de assistência e de ser tutelado.

A relação de tutela do asilo concretizou-se como se fosse uma relação terapêutica. Nele, o louco era mantido afastado de tudo aquilo que podia causar alienação: família, amigos e sociedade. A estratégia do isolamento e da ordem foi utilizada pela medicina mental e orientou toda a prática asilar.

Em meados do século passado, a situação das instituições psiquiátricas agravou-se com a superpopulação e as condições precárias existentes. Ao término da guerra havia uma atmosfera de renovação e reconstrução em todo o mundo. Com a instabilidade sociopolítica, os 
questionamentos das estruturas institucionais intensificaram-se e trouxeram para o contexto social a crise dos manicômios. As denúncias mais comuns eram das condições sub-humanas dos internos, 0 alto investimento financeiro e a baixa resolutividade.

Os manicômios que surgiram com o objetivo de ajuda foram se transformando em locais desumanizados. Uma das críticas mais veementes à instituição psiquiátrica é encontrada na obra Manicômios, prisões e conventos (Goffman, 1974). Como sociólogo, o americano estudou as instituições de regime asilar e retratou o hospital psiquiátrico como um lugar de depósitos de humanos, onde não favorece a reconstrução do eu. Diante desse quadro, foram surgindo estudos e propostas de mudanças, que serão descritos, a seguir, de forma resumida.

\section{A psiquiatria organicista ou biológica}

A partir do estudo de Kraepelin, na Alemanha, a doença mental passa a ser reconhecida como uma alteração orgânica. Práticas como a malarioterapia, insulinoterapia, lobotomia e eletroconvulsoterapia, entre outras, são introduzidas no tratamento a partir dessa concepção (Rocha, 1994).

\section{A psicanálise}

A psicanálise - oriunda dos estudos de Sigmund Freud (1856-1939) sobre as neuroses, após a descoberta do inconsciente e das funções mentais - concluiu que as causas das doenças estão vinculadas a experiências da infância ou a alguma fase do desenvolvimento. Essa tese concedeu o direito de voz aos doentes para contar sua própria história.

O surgimento da psicanálise revolucionou a maneira de lidar com os doentes mentais: não bastava descrever a sua doença, mas também compreender os doentes. A psicanálise mudou a orientação que a psiquiatria 
tinha da doença mental, que passa a reconhecer como uma patologia do psiquismo, fazendo do seu portador um sujeito com uma problemática individual, a ser ouvido (Rocha, 1994; Ribeiro, 1996).

\section{A comunidade terapêutica}

A reforma sanitária inglesa em 1959 teve como marco a consolidação da comunidade terapêutica com Maxwel Jones e tinha como objetivo resgatar a capacidade terapêutica da instituição. Sua base fundamental era a capacitação da equipe, para adoção de medidas democráticas e o incentivo à participação dos pacientes na dinâmica da instituição (Fernandes, 2001). Acreditava-se que o relacionamento estabelecido entre os membros da equipe e a comunidade transformar-se-ia em estímulo para o paciente assumir de forma ativa e responsável seu papel social. Rocha (1994) lembra que os psicofármacos e a eletroconvulsoterapia passaram a ser utilizados em segundo plano.

\section{A psicoterapia institucional e a psiquiatria de setor}

Na França, em 1952, surge a psicoterapia institucional, com base no trabalho de François Tosqueles, desenvolvido na década de 1940, no Hospital Psiquiátrico de Saint-Alban (Amarante, 1995). Um dos objetivos era resgatar os princípios do hospital psiquiátrico estabelecidos por Pinel e Esquirol, ao acreditarem que, nas mãos de um bom médico, o manicômio seria um meio de cura (Desviat, 1999).

A Psicoterapia Institucional reúne no espaço asilar a Psicologia, a Sociologia e outros profissionais da Saúde, como: enfermeiros, assistentes sociais, terapeutas ocupacionais e médicos, onde todos passam a ter um papel terapêutico. A família passa a ser considerada parte integrante no processo de ressocialização e não mais apenas como um fator de alienação. 
Em 1960, a França adota a proposta da psiquiatria de setor à sua política oficial de saúde mental (Pitta-Hoisel, 1984). A proposta do movimento era levar a psiquiatria à população, evitando 0 isolamento do paciente e a restrição de suas relações ao âmbito hospitalar. Este deveria ser tratado na região em que residia mantendo seus vínculos familiar e social. Uma característica interessante, além de ressocializar o paciente, era a proposta de trabalhar com equipes multidisciplinares $\mathrm{e}$ multiinstitucionais.

\section{A psiquiatria preventiva}

A Psiquiatria Preventiva marcou o processo de reformulação da assistência psiquiátrica nos Estados Unidos. O grande diferencial desse modelo foi a prevenção primária, que tinha por fim reduzir novos casos de doença mental na população, por meio de intervenções que neutralizassem os efeitos de circunstâncias perniciosas antes que provocassem distúrbios mentais (Caplan, 1980). O seu movimento desencadeou-se para a política de desospitalização, mas isso não garantiu melhoria da assistência, pelo contrário, resultou em quadro de desassistência.

Apesar das tentativas malsucedidas, dos equívocos e dos objetivos não alcançados desses movimentos, eles suscitaram discussões importantes, trazendo para a arena social as contradições que permeiam o campo psiquiátrico. Além disso, conduziu a uma reflexão sobre a validade das experiências oriundas dessas propostas e, assim, à construção de novos projetos que questionam o conceito de doença mental e o saber médico psiquiátrico.

São exemplos de projetos oriundos da reflexão e questionamento do modelo vigente na época a antipsiquiatria na Inglaterra e a psiquiatria democrática italiana. 


\section{Antipsiquiatria}

A antipsiquiatria foi desenvolvida no início dos anos 1960, do século $X X$, na Inglaterra. Idealizada por um grupo de psiquiatras, cujos destaques foram: David Cooper, Ronald Laing e Aaron Esterson, apresentou-se como um movimento contestador, questionando a adequação do saber e das práticas psiquiátricas no tratamento da loucura, bem como o papel da psiquiatria enquanto saber, a função do hospital psiquiátrico e o método utilizado para formular o conceito de doença mental (Birman, 1982).

A loucura na concepção da antipsiquiatria é uma reação a um desequilíbrio social, sendo que o louco é reflexo dos problemas sociais, é uma vítima. A luta do movimento não foi restrita ao campo da psiquiatria, mas às estruturas sociais, contribuindo para a transformação na percepção da sociedade em relação aos determinantes do contexto social nas doenças mentais (Duarte, 2005).

\section{A psiquiatria democrática}

Em 1961, uma equipe comandada por Basaglia, no hospital psiquiátrico de Goriza, inicia um trabalho de transformação da assistência, por meio de uma prática mais humanizada. O movimento liderado por Franco Basaglia traz uma discussão não apenas restrita aos problemas da psiquiatria, mas assume um caráter político ao colocar as relações políticas e econômicas como determinantes da organização social. Ao perceber os movimentos sociais e o sujeito como atores das mudanças históricas da civilização, acreditou que o modelo asilar, nas suas diferentes reinvenções, é um contraponto para isso, é a maneira de limitar ou calar o processo de criação e participação do homem livre no convívio social (Amarante, 1999).

O movimento basagliano, considerando a vida cotidiana no manicômio, declara este um espaço de segregação e exclusão social. Ele assume uma postura contrária ao que chama de concessionário do poder e 
da violência, "...fizemos nossa escolha, que nos obriga a ficar ancorados ao doente, como resultado de uma realidade que não se pode deixar de questionar." (Basaglia, 1985, p. 132).

Apesar de as alterações ocorridas na assistência do hospital de Goriza terem apresentado melhores resultados, proporcionando melhoria de qualidade de vida dos pacientes, o pedido da equipe para a expansão dessas atividades para centros externos a serem criados não foi atendido, 0 que fez com que seus membros se demitissem após a declaração de cura aos pacientes que ainda se encontravam no hospital.

Na década de 1970, Basaglia e sua equipe assumem a administração do manicômio de Trieste, repetindo a prática desenvolvida em Goriza. Ao darem início ao processo de desconstrução do aparato manicomial, foi marco deste processo:

\footnotetext{
...a destruição dos muros entre o espaço interno do externo; a eliminação de todos os momentos de contenção pela imobilização no leito e a construção de novos espaços de atenção e formas de lidar com a loucura (Oliveira, 2002, p. 57).
}

A desinstitucionalização, na concepção da psiquiatria democrática italiana, não se restringe ao fechamento dos manicômios, mas, essencialmente, à criação de novos dispositivos assistenciais, outras formas de cuidados, de socialidade. A desospitalização em nenhum lugar deve significar desassistência, mas sim melhoria da assistência, tendo como propósito maior a reabilitação psicossocial, isto é, a restituição plena dos direitos, das vantagens, das posições que as pessoas tinham ou poderiam vir a ter se lhes fossem oferecidas outras condições de vida, nas quais as barreiras fossem atenuadas ou desaparecessem (Bertolote, 1996).

Essa transformação da assistência psiquiátrica italiana suscitou importantes reflexões em vários países sobre o hospital psiquiátrico, a doença mental e o saber psiquiátrico. Os pressupostos teóricos da tradição basagliana constituem importantes referenciais para o processo da Reforma Psiquiátrica do Brasil (Birman, 1992). Impossível é se referir à Reforma Psiquiátrica Brasileira sem mencionar Franco Basaglia e suas experiências em Trieste e Gorizia (Basaglia, 1982, 1982, 1985). 
Em síntese, a história da psiquiatria registra dois grandes movimentos de concepção distinta:

a) A institucionalização das práticas terapêuticas durante o século XIX, quando a pessoa doente é retirada da sociedade e internada para receber tratamento.

b) A desinstitucionalização em meados do século $X X$, com movimento oposto, devendo a pessoa retornar para a sociedade e os profissionais garantirem seu tratamento e reinserção social (Silva Filho, Leibing, 1999).

A articulação sociopolítica para a reforma da estrutura de funcionamento dos serviços de atenção à saúde mental está se difundindo pelo mundo por meio de programas governamentais amparados por lei. $\mathrm{O}$ processo de reforma encontra-se em diferentes etapas e cada país enfrenta obstáculos próprios para a sua implementação (Araújo et al., 2003).

Segundo Vasquez (2001), as finalidades da Reforma Psiquiátrica nos países europeus onde os movimentos ganharam mais significância ainda são:

- O desenvolvimento de uma nova organização de um cuidado em saúde mental, de caráter descentralizado e com base territorial.

- Integração dos pacientes psiquiátricos nos cuidados de saúde primária.

- Uma criação extensa de centros de saúde na comunidade.

- Desenvolvimento de atitudes mais positivas sobre o adoecer mental.

Estudos sobre a Reforma Psiquiátrica na Itália, na Espanha e na Alemanha apontam, ainda, a existência de hospitais psiquiátricos, bem como a proibição de admissão de novos pacientes em hospitais mentais estatais, estipulação de serviços de comunidade, hospitalização apenas em unidades pequenas em hospital geral e criação de serviços comunitários e residenciais (Burt, 2001; Bauer et al., 2001).

Vale observar que o novo paradigma da assistência à saúde mental ainda convive com modelos arcaicos em vários países. Entende-se que essa realidade não significa que o processo de Reforma Psiquiátrica seja uma utopia ou algo que não deu certo, mas que se trata da transformação de paradigmas milenares e esbarra em obstáculos que não são removíveis a médio prazo. 


\subsection{A REFORMA PSIQUIÁTRICA NO BRASIL}

A Reforma Psiquiátrica será aqui estudada, na conceituação de Amarante (1995, 1999, 2003), como um processo histórico de formulação crítica, que tem como objetivos e estratégias o questionamento e a elaboração de propostas de transformação do modelo clássico e do paradigma da psiquiatria. Esta Reforma não é somente uma reestruturação do modelo assistencial nem se restringe às transformações sociais e políticas. A reorganização de serviços e sua reestruturação resultam na modernização de práticas terapêuticas e na humanização da assistência, mas estas devem ser entendidas como algumas das características da Reforma Psiquiátrica. Reduzir a Reforma a elas é reduzir a amplitude do processo (Amarante, 2003).

Enquanto processo, a Reforma Psiquiátrica é um movimento que aponta para uma inovação constante de seus atores, para a capacidade de criatividade, conforme os recursos locais de onde se encontram. A Reforma Psiquiátrica apresentada como um "Processo Social Complexo" evidencia: as diferentes dimensões inter-relacionadas, a dimensão do campo epistemológico, o campo técnico-assistencial, o âmbito jurídico-político e a dimensão sociocultural (Amarante, 2003).

A identificação dessas dimensões possibilita uma análise mais crítica do processo e ajuda na sua compreensão, apesar de esta ser impossível na sua totalidade.

O campo epistemológico ou teórico-conceitual, que tem sustentado as práticas assistenciais ao longo do tempo, tem no contexto da Reforma Psiquiátrica outros elementos, ou seja, vieram integrar ao campo teórico (constituído pelos conceitos de alienação, doença mental, normalidade, anormalidade e cura, entre outros) os conceitos de Saúde Mental, Desinstitucionalização e Reabilitação Psicossocial.

O conceito de Saúde Mental que norteia o processo de Reforma Psiquiátrica é de um estado de bem-estar coletivo, decorrente das condições física, psicológica e social, 
...esse caráter social da saúde mental é determinado pelo modo como as pessoas vivem, introjetam o mundo objetivo; objetivam a subjetividade e fantasiam a realidade (Ferreira Filha, Silva e Lazarte, 2003, p. 1)

A Desinstitucionalização como proposta de racionalização e otimização de recursos do Estado (Caplan, 1980), cuja ênfase estava na desospitalização, tem nesse processo outra conotação. Desinstitucionalização é a desconstrução, desmontagem de um aparato assistencial para a oferta de outra modalidade de assistência centrada no espaço do paciente, que vai além da construção de um novo serviço. "É acima de tudo um processo ético-estético, de reconhecimento de novas situações que produzem novos sujeitos de direito e novos direitos para os sujeitos." (Amarante, 2003, p. 91). Ela é aqui entendida como medidas de promoção de vida.

Nesse sentido também está a Reabilitação Psicossocial, que é um conjunto de meios (programas e serviços) que se desenvolvem para facilitar a vida de pessoas com problemas severos persistentes (Pitta, 2001). Para a Organização Mundial de Saúde, Reabilitação Psicossocial é o conjunto de atividades capazes de maximizar oportunidades de recuperação de indivíduos e minimizar os efeitos desabilitantes da cronificação das doenças por meio do desenvolvimento de insumos individuais, familiares e comunitários (WHO, 1987; De Girolamo, 1989).

Para Saraceno (2001, p.16), Reabilitação Psicossocial “...é um processo de reconstrução, um exercício pleno de cidadania, e também, de plena contratualidade nos três grandes cenários: habitat, rede social e trabalho com valor social". Ressalta-se aqui a importância da criatividade e do compromisso dos atores, pois não existe um programa que atenda a todos; a contratualidade acontece de acordo com os interesses dos indivíduos e os recursos próprios de cada cenário.

É fundamentalmente um processo de remoção de barreiras. De barreiras que impedem a plena integração de um indivíduo na sua comunidade e de barreiras que impedem o pleno exercício de seus direitos, da sua cidadania, [...] é a restituição plena dos direitos, das vantagens, das posições que estas pessoas tinham ou poderiam vir a ter, se lhes fossem oferecidas outras condições de vida, nas quais as barreiras fossem atenuadas ou desaparecessem (Bertolote, 2001, p.156). 
A segunda dimensão da complexidade do processo de Reforma Psiquiátrica é a do campo técnico assistencial, que leva ao questionamento da teoria em que o modelo assistencial é sustentado. Nesse campo, a loucura era entendida como incapacidade da razão e do juízo, e o modelo assistencial asilar com a tutela e a vigilância era compatível com a teoria. $\mathrm{A}$ Reforma Psiquiátrica apresenta nova concepção da doença mental e propõe uma assistência com enfoque na saúde mental, que potencialize as capacidades das pessoas e respeite seus limites. Nesse particular, as práticas assistenciais do modelo asilar não atendem os objetivos da Reforma Psiquiátrica.

O campo jurídico-político, em decorrência da noção de que a loucura estava vinculada à periculosidade, irracionalidade e irresponsabilidade, sempre teve peso significativo na assistência à saúde mental; agora, a discussão nesse campo é no sentido de restituir a cidadania aos sujeitos, garantir os direitos humanos e sociais.

A quarta dimensão é a sociocultural, que expressa o objetivo maior do processo de Reforma Psiquiátrica (Amarante, 2003). É neste campo que está o maior desafio para os compromissados com esse processo, porque consiste na criatividade de encontrar meios para a transformação da concepção da loucura na sociedade e, conseqüentemente, sua relação com as pessoas doentes.

A chamada para essas dimensões do processo de Reforma Psiquiátrica muito contribui para a reflexão, para o entendimento de que os profissionais de saúde não são os únicos atores do processo, que desde o início não aconteceu isoladamente. Um processo que se iniciou ainda no período do pós-guerra, quando a reestruturação dos países europeus e as redefinições das políticas sociais nos Estados Unidos constituíram-se em fatores importantes para o questionamento das práticas assistencialistas aos pacientes psiquiátricos, fazendo com que surgissem vários movimentos contestadores que refletiram também no Brasil (Barros, 1996).

O que havia de comum nesses movimentos era o questionamento da eficácia do tratamento asilar, pois, enquanto uns acreditavam na necessidade de transformação do ambiente institucional, outros a negavam. 
No final da década de 1970, o fim do milagre econômico ocasionou a fragilidade da ditadura vigente, surgindo, então, os movimentos populares com expressão contestadora e questionadora das práticas do Governo, dentre eles, vale destacar o Movimento pela Reforma Sanitária, que trouxe para a VIII Conferência Nacional de Saúde propostas de mudanças políticas, jurídicas, sociais e institucionais, que culminaram na proposta do Sistema Único de Saúde (Silva, Barros, Oliveira, 2002).

A luta pela redemocratização e reorganização social do País não poderia ignorar a situação da população institucionalizada, tanto dos presídios como dos manicômios.

As condutas psiquiátricas, até então pouco questionadas pela sociedade, porque sempre fizeram parte do interior dos manicômios, com a liberdade da imprensa, passaram a ser de conhecimento público, sendo tema de discussões e questionamentos.

O Modelo de Assistência Psiquiátrica no Brasil era semelhante ao existente no resto do mundo e criado sobretudo pela influência francesa. $O$ sistema político vigente da época e a concepção da sociedade sobre o louco somado ao poder do psiquiatra fizeram com que a população dos hospícios se tornasse numerosa, tornando impossível qualquer possibilidade de cura ou controle da doença.

Alguns profissionais dão os primeiros passos, engajando-se na proposta transformadora da Reforma Psiquiátrica. A Divisão Nacional de Saúde Mental (Dinsam), órgão do Ministério da Saúde na época, responsável pelas políticas de saúde do subsetor de saúde mental, perde o controle, pois faltam profissionais e condições de trabalho. Os profissionais das quatro unidades do Dinsam, no Estado do Rio de Janeiro, fazem denúncias e entram em greve. Esse movimento ficou conhecido como Crise do Dinsam (Almeida Filho, 2007).

A partir desse episódio, os profissionais organizam-se e surge 0 Movimento dos Trabalhadores de Saúde Mental, considerado por Amarante (1995) como ator e sujeito político fundamental no projeto da Reforma Psiquiátrica Brasileira. Segundo o autor, o movimento surgiu originalmente das propostas de reformulação do sistema assistencial e foi consolidado o pensamento crítico ao saber psiquiátrico (Amarante, 1995). 
Em 1979, acontece, em São Paulo, o I Congresso Nacional dos Trabalhadores em Saúde Mental; as discussões foram sobre os seguintes problemas: a falta de uma política nacional mais ampla e quais medidas os profissionais deveriam tomar para a transformação do quadro assistencial e das condições de trabalho.

O Movimento dos Trabalhadores de Saúde Mental (MTSM) foi se organizando em vários núcleos regionais, buscando estabelecer um diálogo, uma parceria com a sociedade na avaliação e transformação da real situação das instituições psiquiátricas. Houve a realização sistemática de eventos regionais e estaduais, buscando discutir o papel que deveria desempenhar para a superação do modelo hospitalocêntrico (Dalmolin, 2000).

O II Congresso Nacional de Trabalhadores em Saúde Mental foi realizado em Bauru-SP, em 1987, um dos eventos mais marcantes da trajetória da Reforma Psiquiátrica. Foi nele que se estabeleceu a máxima "Por uma Sociedade sem Manicômios", e o dia 18 de maio como o Dia Nacional de Luta Antimanicomial. A partir de então, familiares, usuários e técnicos organizaram o Movimento Antimanicomial, o qual sinalizou a necessidade de uma estratégia política de ação mais ampla, de estabelecer diálogo constante com a população acerca da loucura e tentar redescrever e reconstruir as relações entre a sociedade e os loucos (Almeida Filho, 2007).

Em 1987, acontece também no Rio de Janeiro a I Conferência Nacional de Saúde Mental, orientada pelos mesmos princípios da VIII Conferência Nacional de Saúde, realizada em 1986,

\footnotetext{
...marco fundamental do Movimento da Reforma Sanitária e da história do Brasil, representando o ponto de inflexão na reorientação do modelo da atenção à saúde e, por conseguinte, da própria construção do Sistema Único de Saúde (SUS) (Costa, 2004).
}

A I CNSM evidenciou as dificuldades do modelo assistencial vigente e a necessidade de transformação por meio do enfrentamento nos campos cultural, técnico, político e ideológico. Assim, são criadas ou repensadas novas possibilidades assistenciais importantes (Bezerra Jr, Amarante, 1992). 
A Conferência Regional para a Reestruturação da Atenção Psiquiátrica na América Latina foi realizada em novembro de 1990, em Caracas, e contou com a participação de onze países, inclusive o Brasil, sendo patrocinada pela Organização Pan-Americana de Saúde / Organização Mundial de Saúde (OPS / OMS).

A Declaração de Caracas, como ficou conhecido o documento final desta Conferência, define como essencial a elaboração de modelos alternativos de assistência implantados nas comunidades, tirando o hospital psiquiátrico como centro da assistência e garantindo a manutenção da dignidade pessoal, dos direitos humanos e civis, além da capacitação de recursos humanos em saúde mental e a realização de uma assistência psiquiátrica voltada ao serviço de saúde comunitária que recomende a internação psiquiátrica, quando necessária, em hospitais gerais (Relatorio Final, 1990).

É importante ressaltar que essa Conferência vem demarcar a crescente tendência internacional de superação dos antigos modelos de psiquiatria e Reforma Psiquiátrica, dando legitimidade às transformações que estão acontecendo nos países latino-americanos, até então pouco visíveis (Bezerra Jr, Amarante, 1992).

Nesse contexto, tendo por base os princípios da Reforma Sanitária Brasileira e as diretrizes do SUS, foi realizada a II Conferência Nacional de Saúde Mental, quando aconteceu um

\footnotetext{
...amplo processo de participação e debate, obtido por meio dos trabalhos de 500 delegados eleitos nos eventos estaduais e com composição partidária dos dois segmentos: usuários e sociedade civil, governo e prestadores de serviços (Relatório..., 1994).
}

Foi mais um marco significativo na história recente da política de saúde mental: ratificou a crítica ao modelo hospitalocêntrico e formalizou o esboço de um modelo assistencial a partir dos direitos de cidadão (Costa, 2004). O processo de Reforma Psiquiátrica ganhou grande impulso após a II CNSM, pois inúmeros direitos foram discutidos e aprovados, com o intuito de melhorar a assistência ao portador de distúrbio psíquico e à sua família, objetivando primordialmente sua reinserção ao núcleo social. 
A década de 80 , marcada pela recessão econômica e a insatisfação da sociedade com a má qualidade dos serviços públicos, impulsionou o Estado a reorganizar o setor por meio do regime de co-gestão, o qual visava corrigir as distorções do modelo assistencial, centrado na rede privada, ampliar e preservar as conquistas democráticas com melhoria das condições de vida da população (Figueiredo, 1999). No final desta década, esboçaram-se algumas experiências importantes, como o Centro de Atenção Psicossocial (Caps), na cidade de São Paulo, os Núcleos de Atenção Psicossocial (Naps), em Santos - SP, e a Pensão "Nossa Casa", em São Lourenço do Sul - RS, apontando que era possível tratar o usuário desses serviços de forma humanizada (Costa, 2004).

O Caps de São Paulo, inaugurado em março de 1987, merece destaque por ter sido o primeiro serviço desse gênero criado no País e também um centro irradiador da experiência para outras regiões do Brasil. Nessa perspectiva, em 1989, técnicos envolvidos no Movimento Antimanicomial assumiram a coordenação da política de saúde mental de alguns municípios, desencadeando a construção de novos serviços de acolhimento e tratamento à pessoa com sofrimento mental (Costa, 2004).

Em Santos, o projeto de saúde mental foi uma referência fundamental no processo da Reforma Psiquiátrica no Brasil, pela radicalidade da experiência. Trata-se da primeira experiência inovadora em que ocorreu uma intervenção técnico-legal em um manicômio.

Nos anos 90, dentre as várias experiências importantes no processo de construção da Reforma Psiquiátrica, destacam-se as de Angra dos Reis e Volta Redonda, no Estado do Rio de Janeiro. Em Angra dos Reis, foi implementada a Reforma Sanitária pela Prefeitura Municipal. Esta Reforma rompeu com o modelo tradicional e medicalizador, possibilitando assistência integral, sendo criado o Centro de Atividades Integradas em Saúde Mental (Cais), que funciona como Hospital-Dia e atende psicóticos (Moraes, 2006).

Em 1994, Volta Redonda, no Estado do Rio de Janeiro, transforma seu modelo de assistência, conforme o paradigma da cidade de Santos - SP. Várias outras experiências no campo da saúde mental estão em processo de construção. Serviços de Hospital-Dia, Caps e Naps vêm sendo implantados nas mais diversas regiões do País (Costa, 2004). 
Oficialmente, a Reforma Psiquiátrica no Brasil foi iniciada em 1991, quando o Ministério da Saúde, por meio da Portaria no 189/91, de 19 de novembro, estabeleceu critérios para o funcionamento do hospital psiquiátrico e os grupos de procedimentos da tabela do Sistema Único de Saúde (Amarante, 1995).

Um outro passo importante veio logo em seguida, com a Portaria no 224/92, de 29 de janeiro de 1992, que preconiza a composição de equipe multiprofissional para a assistência à saúde mental e psiquiátrica contendo: médico psiquiatra, clínico geral, psicólogo, enfermeiro, terapeuta ocupacional, assistente social, farmacêutico e nutricionista, bem como o número de pessoas que deve compor a equipe (Brasil, 1992).

Apesar da crescente preocupação com a transformação do modelo assistencial à saúde mental, o avanço na implementação tem esbarrado na falta de articulações políticas e sociais (Vilela, 2002).

A compreensão das propostas da Reforma Psiquiátrica é, por vezes, permeada por doutrinas com diferentes concepções do processo saúde doença mental, refletindo idéias complexas sobre visões de mundo (Barros, 1996). Nesse sentido está o projeto de Reabilitação Psicossocial, que esbarra, entre outros obstáculos, na dificuldade de definição conceitual e operativa (Silva, 2003).

A Lei Federal no 10.216, sancionada em 6 de abril de 2001 pelo presidente Fernando Henrique Cardoso, depois de mais de dez anos de tramitação no Projeto $n^{\circ}$ 3.657/89, de autoria do deputado federal Paulo Delgado (Brasil, 2001), foi o evento mais significativo na luta pela Reforma Psiquiátrica. Esta lei estabelece uma assistência à saúde mental não mais centrada nos hospitais psiquiátricos, preconizando a extinção progressiva dos manicômios e sua substituição por outras modalidades assistenciais. Ela institui, ainda, direito dos pacientes, limita e regulamenta as internações psiquiátricas, substituindo a Lei de 1934.

De 11 a 15 de dezembro de 2001 acontece a III Conferência Nacional de Saúde Mental em Brasília. A III CNSM nasceu com a responsabilidade de ser mais que um campo de discussão, ser também um canteiro para 0 plantio de estratégias que façam germinar, florescer e disseminar ainda mais 
vigorosamente o processo em andamento (Costa, 2004). O tema central "A Reorientação do Modelo Assistencial" teve quatro subtemas: Recursos Humanos; Financiamento; Controle Social e Direito; Acesso e Cidadania.

O relatório registra o que foi realizado nos dois anos anteriores, reafirma princípios e diretrizes do SUS, enfatiza o respaldo da participação social, confirma a desinstitucionalização como estratégia à superação do modelo asilar e exige agilização no processo por meio da regulamentação imediata da Lei no 10.216/06-4-2001 e a construção de serviços substitutivos organizados de modo a formar uma rede (Relatório..., 2001).

Os serviços preconizados como substitutivos ao hospital psiquiátrico são: serviços territoriais de atenção diária em saúde mental de base comunitária-Caps/Naps; oficinas terapêuticas; oficinas de capacitação/produção; ambulatórios de saúde mental; equipes de saúde mental em hospitais gerais; moradias terapêuticas; centros de convivência.

Estes serviços configuram um novo quadro da assistência psiquiátrica no País, ainda não-satisfatório, mas bastante significativo. Com isso, houve uma consolidação da rede substitutiva, dando ênfase aos Centros de Atenção Psicossocial. Os Caps têm uma função estratégica de organização da rede, pois, além de assistir, eles têm responsabilidade pelo território, devem garantir a demanda, não permitir desassistência aos pacientes desse território e têm de garantir seus vínculos com a comunidade (Delgado, 2005).

O desenvolvimento desse processo vem acontecendo no País em conformidade com os recursos e comprometimentos de cada região, cada município. Ao analisar os resultados das propostas da Reforma Psiquiátrica, a partir de abril de 2001, Delgado (2005) aponta que no Plano Político Institucional houve um avanço do arcabouço normativo que produziu uma certa evolução e eficácia, apesar de impedimentos estruturais, como as condições socioeconômicas concretas, que dificultam a implantação dos serviços comunitários. Esse componente influi tanto no quadro epidemiológico quanto na implantação dos serviços.

A transformação do modelo nos últimos anos ocasionou uma redução de aproximadamente cinco mil leitos no País. Uma redução adequada 
considerando as dificuldades, tais como: resistências dos prestadores, gestores e também de profissionais (Delgado 2005).

Para Lima, Fortes e Lovisi (2004), a discussão da Reforma Psiquiátrica tem de considerar as influências da globalização no sistema de saúde brasileiro, no qual o setor de saúde mental se encontra diretamente subordinado.

O processo de Reforma Psiquiátrica no Brasil não acontece no mesmo ritmo do projeto de assistência comunitária que se encontra em andamento em outros países. Acredita-se que o avanço da ideologia neoliberal e da globalização tende a agravar a situação dos pacientes crônicos, pois a lógica de mercado nos sistemas de saúde requer uma política de resultados baseada em evidências de eficácia, o que é muito difícil de ser objetivado no campo da saúde mental (Lima, Fortes, Lovisil, 2004).

A reabilitação psicossocial, principal meta da Reforma Psiquiátrica, depende de vontade política, que envolve uma complexa e delicada maneira de cuidar de pessoas vulneráveis aos modos tradicionais de assistência.

Poderá significar justamente um tratado ético-estético que anime os projetos terapêuticos para alcançarmos a utopia de uma sociedade justa com chances iguais para todos (Pitta, 2001, p. 23).

Ao se considerar a Reforma Psiquiátrica uma necessidade social, cuja maior responsabilidade é da área da saúde mental, também chama a atenção o processo de trabalho da equipe assistencial; este deve estar articulado com a perspectiva da atual formulação política de saúde mental, a inclusão social e se manifestar nas ações práticas cotidianas dos serviços de saúde mental (Silva, 2003).

Uma outra questão do processo de implantação da Reforma Psiquiátrica é com relação aos recursos humanos: a escassez e a qualificação. Preconiza-se a presença de uma equipe de trabalho multiprofissional composta por profissionais de níveis médio e superior das áreas de Enfermagem, Medicina, Psicologia, Serviço Social e Terapia Ocupacional, com atuação interdisciplinar. 
O complexo ato de cuidar, no paradigma da saúde mental, que é, também, o paradigma que trata da produção da cultura, enseja novas formas de compreender e conviver com os diferentes (Prandoni, Padilha, Spricigo, 2006, p. 358).

No entanto, a capacidade de compreensão e convivência com os diferentes envolve uma complexidade, cuja avaliação só é possível na atuação dos profissionais. É preciso a habilitação de profissionais, com a concepção de assistência do novo modelo psicossocial. Os profissionais que continuaram desempenhando o papel que tradicionalmente ocorria no tratamento acabaram comprometendo a prática do processo reabilitativo (Hirdes, 2001).

O encaminhamento da Reforma Psiquiátrica requer especial atenção na atuação dos profissionais e o estudo de Silva (2003) revelou que os serviços têm apresentado uma perspectiva de modernização da instituição sem a transformação de sua essência.

Os profissionais comprometidos em efetivar a Reforma Psiquiátrica deverão desenvolver capacidade para manejar os acontecimentos de modo prático, de forma a produzir algo significativo no seu campo de ação, o que implica com o ato de cuidar e o compromisso de produção de vida (Merhy, 2007).

\subsection{A REFORMA PSIQUIÁTRICA NO PARANÁ}

A Reforma Psiquiátrica, como já descrita, é um processo que acontece de forma não-linear nas regiões do País. No Paraná, esse processo começa a se intensificar no Interior. A Secretaria Estadual e as Secretarias Municipais de Saúde estão empenhadas no processo de Reforma Psiquiátrica desde o início da década de 1990, por meio de encontros dos profissionais da assistência e do ensino, com a participação dos usuários em conferências municipais e estaduais.

A mobilização da comunidade nas Conferências contribuiu para a criação da Lei Estadual da Reforma Psiquiátrica oㅜ 11.189 de 9 de novembro de 1995. A lei de autoria do deputado Florisvaldo Fier, médico pediatra conhecido por doutor Rosinha, nome também atribuído à lei. A Lei Rosinha 
trata das condições de internações dos cidadãos com transtornos mentais e a substituição gradativa de leitos hospitalares por outras modalidades de atendimento (SESA, 1996).

As transformações na assistência à saúde mental no Estado do Paraná começaram a acontecer na capital e na região norte do Estado, onde se encontram serviços com mais tempo de funcionamento e equipes mais estruturadas.

As discussões sobre a implantação da Reforma Psiquiátrica foram intensificadas a partir de 2000, com grupos de profissionais da assistência e das universidades que levaram para os conselhos municipais de saúde as dificuldades do sistema vigente e as propostas da Reforma Psiquiátrica.

Dados do Ministério da Saúde acerca da saúde mental da população acusam que $12 \%$ da população necessitam de algum atendimento em saúde mental; $6 \%$ apresentam transtornos psiquiátricos graves decorrentes do uso de álcool e outras drogas; 3\% sofrem de transtornos severos persistentes, dos quais 38 mil pessoas são do Estado do Paraná (Barleta, 2007). Diante disso, em 2005, a Secretaria Estadual de Saúde (SESA) define a Reforma Psiquiátrica como prioridade.

A Coordenação da Saúde Mental propõe programas e ações de incentivo às iniciativas dos municípios. O Paraná está organizado em 22 microrregiões que têm nas regionais de saúde a instância administrativa intermediária mais próxima aos municípios, cabendo à administração das microrregiões, como órgão regulador do Estado, a incumbência de:

- estimular a criação de políticas municipais em consonância com a Reforma Psiquiátrica;

- articular as negociações regionalizadas;

- fiscalizar e oferecer suporte técnico às equipes na identificação de suas demandas e na busca de respostas às questões do setor de saúde, proporcionando um grau de responsabilização nas ações e controle dos serviços, tanto junto ao Poder Público quanto em relação à participação da sociedade, no sentido de garantir o acesso do usuário aos serviços de saúde, por meio da ampliação e reestruturação dos serviços extrahospitalares (Paraná, 1995), 
A consolidação da Reforma Psiquiátrica depende da articulação de três áreas distintas: legislativa, controle social (por meio de seus conselhos, imprensa promotoria pública) e campo assistencial. O controle social agirá para garantir o cumprimento da lei e o campo assistencial define novas formas de se entender o tratamento e as doenças mentais. Tudo isso vai possibilitar a mudança cultural sobre as doenças mentais e alcançar o objetivo de todo tratamento nessa área, que é a reabilitação social da pessoa com transtornos mentais (Barleta, 2005).

O Conselho Estadual de Saúde Mental do Paraná, em parceria com o Pólo Ampliado de Educação Permanente Centro-Sul e a Coordenação Estadual e Regional de Saúde, em 2005, elaboraram um programa para a realização de seis seminários em todo o Paraná (Pato Branco, Curitiba, Ponta Grossa, Foz Iguaçu, Londrina e Maringá), a fim de estimular o processo de implantação da Reforma Psiquiátrica, mediante discussão e trocas de experiências (Paraná, 2005).

A Reforma Psiquiátrica, em andamento, resultou no crescimento de 3,2 mil vagas para os pacientes em 2002 para mais de 14 mil vagas em 2005, com a abertura de serviços extra-hospitalares, sobretudo os Caps. Atualmente, a rede estadual de assistência é formada por 16 hospitais psiquiátricos com 2449 leitos, 152 leitos psiquiátricos em hospitais gerais e 426 vagas em Hospitais-Dia. Os Centros de Atenção Psicossocial contam com 94 unidades. São 21 residências terapêuticas distribuídas entre cinco cidades: Curitiba, Quatro Barras, Campina Grande do Sul, Cascavel e Maringá, abrigando 149 moradores (SESA, 2007).

Estes dados são divulgados pela Secretaria de Saúde como um avanço e não deixam de ser significativos, mas há outras percepções do processo. Uma delas é que os profissionais têm relatado lentidão na implantação da rede, precariedade das equipes em qualidade e quantidade. A população também vê a proposta de maneira crítica. $O$ jornal Gazeta do Povo, na edição do dia 27/3/2006, em uma matéria cujo título é "Reforma Psiquiátrica tem lado cruel", denuncia os efeitos das falhas no planejamento e gestão da Reforma Psiquiátrica (Bumardo, 2006). 
Criado para acabar com tratamento desumano em hospitais, o projeto deixa pacientes e famílias em dificuldades. A Reforma Psiquiátrica começa a apresentar seus efeitos colaterais. Assim é introduzida a denúncia de desassistência nas cidades em que a extinção dos hospitais antecedeu a implantação da rede substitutiva. As famílias nem sempre conseguem dar a assistência que eles precisam: faltam recursos, tempo e habilidade para cuidar do paciente. Sem suporte, muitos deles acabam como andarilhos e/ou voltam às filas para reinternação em outras localidades. No Centro Psiquiátrico Metropolitano em Curitiba, a espera pela vaga oscila de quatro a seis meses e, segundo o Ministério Público, 40\% dos pedidos não são atendidos (Bumardo, 2006).

Essa situação veio em decorrência da falta de planejamento que priorizasse a Reforma Psiquiátrica, seguindo as etapas de sua proposta, pois houve o descredenciamento de leitos psiquiátricos antes da construção dos serviços da rede que iria substituí-los (Dias, Mion, 2004).

Mas onde a Reforma foi criteriosamente implantada, os resultados são satisfatórios. Na cidade de Castro, o secretário de Saúde revela que após implantação do Caps, as internações diminuíram significativamente. (Agência Estadual de Notícias, 2007).

A Reforma Psiquiátrica no Paraná ainda é um desafio: para as universidades, o desafio é a formação de profissionais, com uma concepção do novo paradigma, que se comprometam com o processo; para os gestores, o entendimento do processo para priorizar as ações de assistência à saúde mental e, para os profissionais, a tenacidade para insistir na efetivação, apesar das adversidades. 


\subsection{A ENFERMAGEM BRASILEIRA NO CONTEXTO DA REFORMA PSIQUIÁTRICA}

Para falar sobre a enfermagem neste contexto de Reforma Psiquiátrica, é necessário resgatar um pouco da sua origem para entender e avaliar sua atuação no processo.

A história da enfermagem psiquiátrica está relacionada com a dos manicômios e com a do poder médico. A sua formação e o seu exercício iniciam-se no Brasil sob o controle médico psiquiátrico. Desde a fundação da primeira escola em 1890, no Rio de Janeiro, até os anos 1940, a formação do pessoal de enfermagem foi assumida pelos psiquiatras tanto nas escolas como nos estabelecimentos psiquiátricos (Kirschbaum, 1997).

A formação profissional enfatizava as práticas disciplinadoras, usando como estratégia: o controle, a repressão e o respeito (obediência) à hierarquia. Dentre as práticas disciplinadoras mais aplicadas estavam: proibição de visitas, redução dos alimentos, reclusão e colete de força, todas determinadas pelos médicos, mas quem as praticava eram os enfermeiros, que também determinavam essas práticas em situações de emergência. Essa autonomia fez com que o emprego da força física se tornasse freqüente no trato com os internos (Rocha, 1994).

A enfermagem mantinha uma postura autoritária com as pessoas internadas, mas, ao mesmo tempo, permanecia submissa às determinações médicas. Fazia parte do seu cotidiano ser opressora e ser oprimida. Mesmo reconhecida como profissão, ela continuou subalterna e dependente e sua participação na organização e execução dos cuidados foi, por muito tempo, direcionada pela importância da manutenção da disciplina nas instituições. Nos anos de 1950, quando essa profissão procura delinear uma fundamentação para as técnicas de enfermagem, centra suas bases principalmente na área biológica (Almeida, Rocha, 1986). 
A enfermagem desenvolveu-se fundamentada no discurso psiquiátrico, cuja concepção predominante é a organicista - que entende a doença mental como um desajuste do organismo, desvinculado do ambiente, compreendendo que os fatores psicossociais podem ser apenas agravantes.

A enfermagem psiquiátrica parece ter sucumbido no interior dos manicômios, único espaço de atuação que lhe foi possível ocupar por muito tempo sem nenhuma posição de maior vulto ou adversa às determinações médicas. Essa posição foi fortalecida pelo sistema de ditadura pelo qual o País viveu até os anos 1980.

Já no final dos anos 1970, a concepção psicológica da doença mental começou a ser tema de discussão nos currículos dos cursos de Enfermagem e explica a origem da doença como sendo parte da história do sujeito, de seu inconsciente e das relações interpessoais. Ela surgiu nos Estados Unidos, é conhecida por Psicologia Humanística e enfatiza aspectos comportamentais (Furegato, 2000).

O trabalho de Sullivan (1953), cuja teoria interpessoal explica a evolução dinâmica da personalidade como fenômeno social, definindo o papel terapêutico do psiquiatra por meio das relações interpessoais, desperta a atenção de enfermeiras recém-formadas que se apegam ao conceito de que o doente mental tinha partes sadias e que a assistência deveria direcionar-se para ampliar esse potencial e que havia possibilidade de modificar aquela situação se quisesse.

Nessa corrente, deu-se a propagação da Teoria das Relações Interpessoais para a Enfermagem, formulada na década de 1940, cuja ênfase é a valorização da relação como meio terapêutico (Peplau, 1952). Travelbee (1979) aponta a relação interpessoal como a essência da Enfermagem Psiquiátrica, devendo o enfermeiro buscar uma interação com o paciente para ajudá-lo a encontrar suas próprias soluções e a sair mais fortalecido do processo da doença.

A situação dos pacientes internados apresentava-se degradante. Mais que informação da necessidade de transformação na assistência, havia a necessidade de outra mentalidade, pois a proposta do alienismo não só 
transformou os hospícios em espaço de exclusão social, como também produziu um saber próprio sobre a loucura e os meios de curá-la (Kirschbaum, 1997). Era vital a construção de um novo saber, novos conceitos que direcionassem nesses enfermeiros um olhar diferente ao paciente - de uma pessoa com direitos, sentimentos e capacidade e não simplesmente uma pessoa doente e incapaz.

No contexto da Psicologia Humanística, identificou-se um destaque do enfermeiro no tratamento do paciente, ele deixa de ser apenas um executor de determinações médicas para ser responsável pelo estabelecimento de um ambiente terapêutico, capaz de promover maior capacidade para as pessoas enfrentarem seus desafios.

Segundo Rodrigues (1993), a equipe de enfermagem, ao assumir uma postura humanística no cuidado ao paciente, descentraliza a assistência do médico e da própria enfermagem e tem como foco as necessidades reais do paciente, podendo atendê-las com mais objetividade. É sabido que as práticas não mudariam senão antes da mudança da concepção e as escolas adequaram seus conteúdos trabalhando conceitos embasados na Teoria das Relações Interpessoais para a Enfermagem (Peplau, 1952).

A teoria das Relações Interpessoais para a Enfermagem serviu para reorientar a atenção aos pacientes, que vinha sendo direcionada, até então, pelo olhar clínico do médico. Os enfermeiros passam a olhar o paciente como um ser único, tal como ele é, buscando compreendê-lo de maneira humanitária, considerando a relação enfermeiro-paciente, terapêutica (Aguiar, 1995).

Nessa sentido, o relacionamento é entendido como um meio pelo qual o enfermeiro pode ajudar 0 paciente a compreender o próprio comportamento, a integrar sua capacidade e a aprender a manipular seus problemas (Minzoni, 1980).

O relacionamento terapêutico enfermeiro-paciente é constituído de uma série de interações, planejadas pelo enfermeiro com objetivos definidos para ser útil a um paciente em particular, que, por uma situação qualquer de vida, se viu impedido de interagir ou se comunicar satisfatoriamente com as pessoas de seu meio (Stefanelli, 1983). 
Mas, a mudança do olhar, a escuta e a relação mais humanizada continuavam tendo suas bases, segundo Silveira (1990), em um paradigma racionalista, cuja característica é a reprodução mecânica da ordem.

Essa responsabilidade também confere mais valorização ao trabalho dos enfermeiros. Identificou-se como algo positivo na prática humanística a postura da enfermagem, que passa a ser participativa e assume parte da responsabilidade no plano terapêutico. No entanto, é uma prática que enclausura o paciente e uma relação de dependência, quando desconectada do seu meio social.

É impossível negar a contribuição das duas concepções - psiquiátrica e psicológica - para a compreensão e organização da assistência à saúde mental. A concepção psiquiátrica organicista contribuiu para o conhecimento da fisiologia neurológica, possibilitando maior compreensão da intervenção medicamentosa como alívio do sofrimento psíquico, por exemplo. A concepção psicológica do referencial humanístico contribuiu para uma assistência mais humanizada aos pacientes, destacando-se, como exemplo, a valorização de sua história contada por ele próprio e a atuação da enfermagem de maneira mais autônoma.

Mas, frente às transformações que vêm ocorrendo no campo da saúde mental, os enfermeiros deparam-se com o desafio de refletir sobre a própria atuação profissional, no sentido de desenvolver uma nova prática assistencial, que vai além da terapia medicamentosa e de ações humanísticas, “...precisam reconhecer seu papel político, sua função educativa e exercitar a análise e a crítica da realidade." (Ferreira Filha, Silva, Lazarte, 2003, p.1).

O modelo psicossocial proposto pela Reforma Psiquiátrica pressupõe a oferta de novos dispositivos que configurem espaços diferenciados para acolher e garantir a atenção integral à saúde mental. A proposta assistencial deve estar direcionada ao cotidiano das pessoas em sofrimento psíquico e se propor a mediar a construção de outros espaços, que possibilite a manutenção dos vínculos familiares e a criação de novas relações nos campos afetivo, social e político. 
A reforma na assistência à saúde mental tornou-se uma realidade incontestável. Sabe-se que o fim dos manicômios, por si só, não significa melhoria na assistência às pessoas. A atuação do enfermeiro tem se expandido, pois ele começa a experimentar novos papéis em ambulatórios de saúde mental, Hospitais-Dia e núcleos de reabilitação psicossocial, entre outros (Ribeiro, 2005).

Com isso, os serviços de atendimento têm uma dinâmica que requer do enfermeiro mais que saber técnico científico, ou seja, requer uma visão ampliada sobre a vida e seus diferentes valores, como cidadania e socialidade. Enquanto o modelo clássico o mantinha dentro da instituição entre o psiquiatra e o paciente, o novo paradigma o coloca em grupos multiprofissionais e o impele a vivenciar o cotidiano do paciente, exigindo dele capacidade de interação com os familiares e a comunidade.

As ações de enfermagem não devem ser desarticuladas do contexto social. Profissionalmente, os enfermeiros têm de ser "modestos" e não acreditar que podem sozinhos dar assistência ao paciente ou fazer sua parte isoladamente.

No decorrer da história, as reformas de assistência traziam uma ênfase em determinado objetivo: a concepção organicista visando o tratamento da "doença" enfatiza a medicação e o controle do paciente em sistema asilar; a concepção humanística dá ênfase ao relacionamento interpessoal enfermeiro-paciente, enquanto o modelo psicossocial dá ênfase à reabilitação e à inclusão social.

Os enfermeiros encontram-se em um exercício de reflexão sobre seus conceitos e adaptação às novas práticas, que se encontram em construção com muitas contradições nas novas modalidades de serviços de atenção à saúde mental (Souza, 2003).

Estudos realizados em vários pontos do País têm demonstrado que há ainda na prática dos enfermeiros muitos resquícios do modelo asilar e uma expressão não muito clara do novo paradigma (Oliveira, 2002; Miranda, 2002; Barros, 2005; Luchese, 2005). 
A introdução de novos referenciais quase sempre vem abalar a estrutura já instalada, provocando crises, levando à busca de outras estratégias e novas posturas. É pertinente lembrar a importância de: valorizar os aspectos relacionados ao simbólico-afetivo; entender as necessidades humanas por meio das questões da subjetividade e trabalhar com o conceito de doença como uma construção social e histórica, para não se estagnar em uma crise de teorias, saberes e ciências (Machado, Lavrador, 2001).

A proposta da Reforma Psiquiátrica, o modelo psicossocial, visa uma assistência articulada com o contexto de vida do paciente; contudo, a maioria das atividades e das ações de saúde para eles é desenvolvida no interior da instituição, indicando a necessidade de avaliação do serviço e de buscar aprofundamento, para que o desempenho de suas atividades sejam coerentes com os pressupostos do campo psicossocial (Aranha, Silva, 2003).

\subsection{COTIDIANO DOS ENFERMEIROS NOS SERVIÇOS DE SAÚDE MENTAL}

\footnotetext{
"Nossa prática profissional deve procurar o diálogo intra $e$ interdisciplinar, revendo e analisando os elementos estruturais que compõem a essência das atividades dos enfermeiros."

Machado e Colvero
}

Nesta etapa, discorrer-se-á acerca do cotidiano na pós-modernidade, da reabilitação psicossocial como objetivo dos serviços de saúde mental e do cuidado como a principal ação das práticas desenvolvidas pelos enfermeiros. Frente à concepção de reabilitação psicossocial que se apresentou neste estudo, entende-se que, sem considerar os aspectos do cotidiano na elaboração do cuidado, a assistência tende a ser ineficaz.

O cotidiano é estudado em várias correntes no campo das ciências sociais, dentre elas a corrente histórica de Michel de Certeau e a marxista de Agnes Heller. O cotidiano é aquilo que nos é dado a cada dia, que nos prende intimamente a partir do interior (Certeau, Giard, Pierre, 2003). A vida cotidiana é a vida do homem inteiro (Heller, 1992). 
Estes dois autores foram pontuados porque seus conceitos parecem compatíveis com os aspectos dominantes e mais perceptíveis da vida, os que tratam da organização formal, na qual se está inserido; “...o homem nasce inserido em sua cotidianidade" (Heller, 1992).

Mas, foi eleita como norte para o estudo do cotidiano dos enfermeiros a corrente sociológica, em uma visão contemporânea com os conceitos de Michel Maffesoli, por considerar que estes contemplam aspectos pessoais e sociais das relações estreitas de pequenas ações. Seus estudos apresentam as pessoas como atores de seu cotidiano. Para ele, o cotidiano é a história do dia-a-dia de cada um de seus participantes e, neste contínuo de pequenas ações, se forma a base em que foram elaborados os conhecimentos e entendimentos do social (Maffesoli, 2005).

O cotidiano é local de perpetuação das representações, entre pessoas, por meio da troca de sentimentos, discussões diárias, conversas em uma mesa de bar sem consistência e outras situações corriqueiras, que nos envolvem na trama diária e realiza a vida (Maffesoli, 2005). É nessa perspectiva que se direcionou o olhar para o cotidiano dos enfermeiros nos serviços de atenção à saúde mental, pois, se no cotidiano se realiza a vida, também é nele que se produz a doença e a saúde.

As pequenas atitudes diárias, os trajetos, as bricolagens, os afetos, as paixões e os prazeres - como: comer, beber, tagarelar, amar e passear constituem a poética do cotidiano (Maffesoli, 1998). Por meio dessas atitudes, as pessoas afirmam-se como grupo, dando origem a uma socialidade que se expressa pelas relações humanas, mantendo suas identidades individual e coletiva (Maffesoli, 2001).

O convívio social é freqüentemente considerado na avaliação da saúde das pessoas e se percebe que essas pequenas atitudes, muitas tomadas na espontaneidade, são significativas no contexto da saúde mental. Na medida em que a produção de subjetividades acontece nas interações sociais, esta é essencialmente fabricada e modelada no registro do social (Guattari, 1986).

As ações que compõem o cotidiano dos enfermeiros nos serviços de saúde mental acontecem em grupos diferentes, tais como: 0 dos profissionais, o dos pacientes e seus familiares e a comunidade onde estão 
inseridos. Na atenção e valorização dos fatos corriqueiros e pequenos do dia-a-dia, os enfermeiros poderão ter a percepção de importantes subsídios para a organização das ações assistenciais.

Os enfermeiros são freqüentemente afetados em seu cotidiano, pois o convívio com diferentes ações e histórias nos induz a um determinado comportamento e desempenho, sendo que a qualidade dependerá de como trabalhamos com as informações, da nossa capacidade de compreensão e da criatividade em superar situações de conflitos e potencializar as possibilidades positivas.

O cotidiano é um estilo que, em determinado tempo, abrange o ambiente e o concreto vivido em sua totalidade, apresentando-se como causa e efeito do conjunto das relações sociais. O estilo evidencia as atitudes emocionais, as maneiras de pensar e agir nas formas de relação com o outro e, com isso, define uma cultura (Maffesoli, 1995). O cotidiano pode expressar compreensão de saberes, assimilação de conceitos, sensibilidade ética e costumes (Maffesoli, 1998).

Ao serem pontuados esses aspectos, não estamos indiferentes nem negando outros elementos do cotidiano, aqueles que são partes orgânicas da vida cotidiana: a organização do trabalho e da vida privada e a atividade social sistematizada que se apresentam com mais evidência e que, segundo uma visão positivista, são os mais reconhecidos e comumente se sobrepõem.

Heller (1992) apresenta a vida cotidiana como sendo heterogênea e hierárquica, principalmente no que se refere ao conteúdo e à significância das nossas atividades. Enquanto a heterogeneidade é constante, a hierarquia modifica-se de modo específico em função das diferentes estruturas econômico-sociais.

No contexto da atenção psicossocial, a noção atribuída ao cotidiano por Goldberg (1998) é a de que sua natureza é de objeto total e expressa a dinâmica mais intrínseca e transcendente da vida das pessoas. Quando o homem vive sua vida cotidiana plenamente significa que está empenhando os estratos de sua existência, desde os mais simples e concretos aos que revelam as suas abstratas inquietações espirituais. O cotidiano, então, é sempre 
constituído de conteúdo simbólico. O autor, prosseguindo no raciocínio, lembra que a característica do transtorno mental grave é o rompimento temporário dos pacientes com sua cotidianidade e que, ao atingirem algum equilíbrio, recompõe uma cotidianidade sem adesão ou reconhecimento social.

Cabe aos serviços de atenção psicossocial possibilitar e, na medida do possível, tornar as pessoas capazes de exercer seus direitos de viver e conviver nos diversos grupos sociais e no cotidiano que estavam inseridos antes do processo da doença. Dessa forma, o grande desafio da Reforma Psiquiátrica é a reabilitação psicossocial.

Assim, surge a necessidade de readequação das ações de enfermagem de forma a priorizar o social. Tornam-se necessárias a aderência de novos conceitos em relação ao doente mental e uma postura de reconhecimento da pessoa como cidadão, com direitos de participação no seu tratamento e não mais como um paciente passivo às decisões dos profissionais e cuidadores.

O cotidiano nos serviços de saúde mental é permeado por elementos antagônicos e contraditórios que devem ser observados, uma vez que determinam as ações dos enfermeiros e seus resultados, podendo ser também fatores de tensão. Para o enfermeiro se tornar promotor de reabilitação psicossocial, é preciso ampliar seus conhecimentos para além da área de saúde, desenvolvendo habilidade para o trabalho em equipe, de forma interdisciplinar, comprometendo-se com a promoção de vida de cada pessoa sob seus cuidados.

A reabilitação psicossocial é uma formulação útil que permite superar a dicotomia entre o sujeito e o contexto presentes no nascimento da psiquiatria; significa o restabelecimento da contratualidade de cidadão, de produzir novos sentidos e valores sociais. A função da reabilitação na psiquiatria é a dignificação desse sentido, o acompanhamento do paciente na recuperação de espaços não protegidos, mas socialmente abertos de produção (Saraceno, 2001).

Para Pitta (1996), no seu sentido instrumental, a reabilitação psicossocial representa um conjunto de meios (programas e serviços) que se desenvolvem para facilitar a vida de pessoas com problemas severos e persistentes de saúde mental. 
Reabilitação psicossocial é uma atitude estratégica, uma vontade política, uma modalidade compreensiva, complexa e delicada de cuidados para pessoas vulneráveis aos modos de sociabilidade habituais que necessitam cuidados igualmente complexos e delicados (Pitta, 1996, p.21).

Isso parece estar claro para todos os profissionais que trabalham com a saúde mental. A questão é como fazer, quais práticas adotar, criar, já que não existe um programa válido para todos em todos os lugares. O primeiro passo no processo de reabilitação psicossocial deve ser conhecer o território, a comunidade em que as pessoas sob nosso cuidado estão inseridas. Com isso, há possibilidade de identificação de barreiras e de prováveis aparatos de suporte, visto que o cuidado na concepção apresentada por Lopes (1995), da qual compartilhamos, não é uma ação independente, mas interdependente construída no cotidiano.

Diante disso, entende-se o cuidado como uma atividade essencial da prática social da profissão (Machado, Colvero, 1999); ele engloba atitudes técnicas e comportamentais, dimensões objetivas e subjetivas. Quando o enfermeiro se inteira dessas dimensões do cuidado, ao assistir as pessoas, consegue ajudá-las a se tornar mais fortes, porque valoriza suas potencialidades de organizar suas vidas.

O cuidado não pode ser um ato isolado desarticulado do contexto de vida. Cuidar é um ato social que só atinge a sua plenitude se tiver em conta um conjunto de dimensões sociais (Collière, 1989). Este é um dos aspectos fundamentais quando se pensa em reabilitação psicossocial, pois há de se considerar a fonte social que é o cotidiano, com a perpetuação das representações entre as pessoas, as trocas de sentimentos e experiências onde a vida acontece (Maffesoli, 2005).

A atuação dos enfermeiros, nesse cenário, ganha uma outra característica, a da interdisciplinaridade, que é importante ser diferenciada da multidisciplinaridade, a qual agrega profissionais de diferentes áreas, atuando de forma independente, com uma visão fragmentada da pessoa. $\mathrm{Na}$ interdisciplinaridade, o conjunto de diferentes profissionais trabalha de forma articulada com suas áreas de conhecimento, cientes de que nenhuma delas tem uma visão completa da pessoa (Costa 1996). 
Atuar de maneira interdisciplinar requer diálogo e humildade, instrumentos básicos para lidar com o desafio, diante do desconhecimento e possibilitar a troca de conhecimento e ações, distribuindo a responsabilidade entre os membros da equipe sem descaracterizar as especificidades da profissão de cada um (Dias,Schneider,Durman, 2005). Para estes autores,

\begin{abstract}
....a interdisciplinaridade ainda não se estabeleceu em toda sua dimensão. Os obstáculos vão desde a crise na identidade interdisciplinar até a homogeneização / universalização dos conceitos, muitas vezes inconciliáveis (Dias,Schneider,Durmam, 2005; p.384).
\end{abstract}

Nesse sentido, priorizando os objetivos da atenção psicossocial, de cuidar e possibilitar a reabilitação social, acredita-se ser importante avançar para o estabelecimento da interdisciplinaridade revendo nossos conceitos. Vale ressaltar que o cuidado na atenção psicossocial tem pontos relevantes que só são possíveis de serem atingidos por meio da ação interdisciplinar, tais como: a relação com o usuário e suas implicações subjetiva e sociocultural; a valorização do cliente como participante principal do tratamento; o incentivo para que a família e a sociedade assumam seu compromisso na atenção e no apoio à pessoa em sofrimento psíquico e, sobretudo, a ênfase para reinserção social (Kantorski et al., 2006).

Apesar da oficialização da Reforma Psiquiátrica ser o resultado de mais de três décadas de discussões e da avaliação crítica do modelo clássico, bem como a comprovação de sua ineficácia, os profissionais ainda apresentam dificuldades em desenvolver suas atividades.

O hospital psiquiátrico ainda é uma presença muito forte e faz parte do cotidiano de uma grande parte dos enfermeiros. Ainda há contradições significativas entre o modo de pensar e o de operar dos enfermeiros (Casanova, 2002). Em alguns serviços assistenciais, eles têm desempenhado atividades de natureza burocrática e administrativa (Oliveira, Fortunato, 2003).

Os Caps, segundo a Portaria nำ 336/GM/2002, visam prestar atendimento em regime de atenção diária; gerenciar projetos terapêuticos, oferecendo cuidado clínico eficiente e personalizado, e promover a inserção social. A referida Portaria atribui, ainda, aos Caps a 
responsabilidade de organizar a rede de serviços de saúde mental de seu território, bem como dar suporte e supervisionar os atendimentos à saúde mental na rede básica.

Inseridos nos Caps, os enfermeiros deveriam estar aptos para desenvolverem em conjunto com a equipe ações que concretizem as propostas da Reforma Psiquiátrica. Entretanto, há carências de tempo e capacitação dos profissionais, pois o Ministério da Saúde, ao permitir o funcionamento de serviços com equipe mínima, inviabiliza a extensão das suas atividades, tornando difícil até o desenvolvimento das atividades aos pacientes no próprio centro.

$\mathrm{Na}$ busca de estabelecer uma relação assistencial mais abrangente com o portador de doença mental, os enfermeiros estão se encontrando em espaços comumente esquecidos no modelo clássico: os espaços familiar e social. Os enfermeiros com maior ou menor freqüência têm buscado compreender as mobilizações psicossociais que orientam a vida cotidiana dos familiares decorrentes do convívio com um de seus integrantes doente mental (Colvero, 2002).

O trabalho com grupo de familiares e com uma família em particular visa propiciar a criação de vínculos de solidariedade entre elas e um espaço de discussão de seus problemas em comum.

A estratégia do grupo é muito utilizada. A ação dos enfermeiros requer uma postura dinâmica na condução dos grupos, pois, ao mesmo tempo que têm a responsabilidade de organizar os grupos, precisam motivar seus integrantes a serem participativos, sentindo-se responsáveis no projeto terapêutico.

A orientação é uma outra atividade sempre realizada pelos enfermeiros nos Caps. Trata-se de uma conversa de assessoramento individual, ou em grupo, sobre algum tema específico, sendo os mais comuns: tratamento medicamentoso (indicações, posologia, efeitos colaterais), a doença e sua evolução (sinais de alerta), o uso de drogas, prevenção de doenças e autocuidado.

Por outro lado, as atividades comunitárias utilizam os recursos da comunidade, envolvem pessoas, instituições ou grupos organizados 
atuantes na mesma, haja vista Festa Junina do bairro, feiras, quermesses, campeonatos esportivos, passeios a parques e cinema, entre outras, de valores significativos e próprios de cada comunidade.

Ainda em conformidade com o MS, os Caps devem também desenvolver atividades de suporte social: projetos de inserção no trabalho, articulação com os serviços residenciais terapêuticos, atividades de lazer, encaminhamentos para a entrada na rede de ensino, para obtenção de documentos e apoio para o exercício de direitos civis através da formação de associações de usuários e/ou familiares.

Os Centros e Núcleos de Atenção Psicossocial, bem como todo dispositivo proposto pela Reforma Psiquiátrica apresentam uma complexidade não-familiar aos profissionais e à sociedade. Suas propostas ainda se chocam com desempenho de uma assistência fundada com conceitos do modelo clássico.

As ações que vêm sendo desenvolvidas com mais freqüência pelos enfermeiros, citadas em estudos bibliográficos (Kantorski et al., 2006; Colvero, 2002; Oliveira, Alessi, 2003; Souza 2003) são: acolhimento; monitoramento de grupos de trabalho e terapêuticos; participação e coordenação de reuniões com familiares e equipe de trabalho, onde buscam debater temas relacionados com a reabilitação psicossocial das pessoas sob seus cuidados. As atividades de expressão corporal, como dança, pintura, música, oficinas culturais, teatro e psicodrama, além de jogos e atividades de exercícios físicos em grupos funcionam como facilitadores de socialização.

Outro campo de atuação dos enfermeiros são as moradias assistidas inseridas na comunidade, destinadas a cuidar dos portadores de transtornos mentais com graves dependências institucionais, que não tenham possibilidade de desfrutar de inteira autonomia social nem possuem suportes social e familiar adequados. Esses serviços devem atuar como suportes familiar e social na vida desses indivíduos, promovendo sua reinserção gradual à vida comunitária, buscando a melhoria na qualidade de vida, considerando limites e vulnerabilidades de cada um (Brasil, 2004). 
As moradias devem possibilitar às pessoas que passaram por longos períodos de internação viver em um clima familiar, sob a tutela de uma equipe assistencial, tendo por objetivo a sua reintegração na sociedade. Criadas para serem locais de transição de caráter terapêutico integradas em programas de reabilitação e reintegração, por vezes convertem-se em alojamento definitivo, pela carência de familiares, falta de outro recurso social ou impossibilidade de uma reintegração profissional (Espinosa, 2000).

O cuidado no espaço das moradias também é algo que está sendo construído e é de grande complexidade. Há de se cuidar para não transformá-las em outras instituições assistenciais e descaracterizá-las de moradias, de um espaço privado próprio do paciente.

A relação dos profissionais com os moradores amplia-se e se transforma de uma relação de tutela para uma outra, contratual; assim sendo, as ações dos enfermeiros devem estar fundamentadas na reciprocidade com o morador, buscando novos espaços de convivência, criando e resgatando vínculos sociais (Prandoni, Padinha, Spricigo, 2006).

A ação deles no espaço das moradias é um desafio, um exercício de parceria e reconhecimento dos direitos de quem cuida. Para Covino (2007, p.102), “...as moradias representam um verdadeiro espaço híbrido, ao mesmo tempo, rico de possibilidades e inquietante”.

O desafio está em transformar, no cotidiano, os conflitos das diferenças em possibilidades de crescimento; mas, para isso, é necessário criar práticas consistentes e coerentes com o conceito de cidadania e reabilitação psicossocial.

Estudos têm demonstrado que os enfermeiros convivem com muitas deficiências no cotidiano dos serviços de assistência à saúde mental, tais como: a falta de experiência em saúde mental, como falta também do embasamento teórico focado em um conhecimento contextualizado e criativo (Oliveira, 2002); a organização do processo de trabalho das equipes (Amaral, 1997); as limitações em interagir com profissionais de outra área na rede e o trabalho interdisciplinar, bem como dificuldades para sua formação e atualização (Souza; Alencaster; Saeki, 2000). 
Mesmo com limitações, os enfermeiros vêm se empenhando no processo de efetivar as propostas da Reforma Psiquiátrica. Estudo aponta que

...a carência de um referencial teórico sobre reabilitação psicossocial não impede que os profissionais construam suas práticas de maneira muito próxima às apresentadas pelos teóricos, o que faz pensar que o processo de transformação da assistência psiquiátrica já se encontra internalizado em seus operadores (Ribeiro, 2005, p.113). 


\section{PERCURSO METODOLÓGICO}

\subsection{A PESQUISA QUALITATIVA}

A tradição dominante da pesquisa científica é lógico-experimental, por força da expectativa modernista da experimentação matematicamente controlada (Demo, 2001). Na linha do Positivismo, os fenômenos deveriam ser estudados objetivamente e apresentar resultados concretos e comprovados de forma inquestionável. Esta abordagem, todavia, não responde a questões relacionadas à subjetividade humana, limitando, assim, os estudos sobre a percepção e outros aspectos abstratos do homem.

Com a ascensão das Ciências Sociais surge uma nova maneira de estudar os fenômenos e eventos sociais, uma abordagem qualitativa em que se privilegia mais a profundidade dos fenômenos do que sua extensão e freqüência. "É proposta necessária pelo simples fato de que fenômenos qualitativos precisam ser captados qualitativamente, sem perder de vista sua formalização implícita no campo do método científico." (Demo, 2001, p.10).

O surgimento da abordagem qualitativa possibilitou o avanço da compreensão de aspectos próprios do ser humano, que não são alcançados pelos estudos quantitativos. Todas as questões relacionadas com 0 Significado e a Intencionalidade inerentes aos atos, às relações e às estruturas sociais são incorporadas pela Pesquisa Qualitativa (Minayo, 1997). A pesquisa na área da Saúde, em especial na Enfermagem, tornouse bem mais expressiva com o reconhecimento e o advento da abordagem qualitativa.

A presente pesquisa define-se como qualitativa por se entender que seu objeto de estudo traz questões muito particulares, “...um universo de significados, motivos, aspirações, crenças, valores e atitudes, o que corresponde a um espaço mais profundo das relações dos processos e fenômenos...”, características que Minayo (1997, p.22) cita serem compreendidas com essa abordagem. 


\title{
4.2 A ESTRATÉGIA DO DISCURSO DO SUJEITO COLETIVO
}

O Discurso do Sujeito Coletivo é uma técnica que

\begin{abstract}
...busca dar conta da discursividade, característica própria e indissociável do pensamento coletivo, buscando preservá-la em todos os momentos da pesquisa, desde a elaboração das perguntas até culminar com a apresentação dos resultados (Lefèvre, Lefèvre, 2003, p.11).
\end{abstract}

O Discurso do Sujeito Coletivo surgiu das inquietações do autor em relação a outras propostas de tratamento dos dados na pesquisa. Segundo ele, as propostas se reduzem a três possibilidades: a requantificação dos discursos / depoimentos pela análise de conteúdo dos discursos, identificando os pontos de convergência; a requantificação dos discursos/depoimentos pelo mecanismo da categorização e a requalificação teórica.

O autor entende que essas propostas desconsideram a discursividade, que é um traço constitutivo do pensamento coletivo como fato empírico. Na primeira proposta, ele vê uma redução do discurso em palavras ou elementos e que isso compromete a apreensão dos significados dos depoimentos. Na seguinte, há um afunilamento dos discursos, forçandoos a se encaixarem em uma categoria. Na terceira, ele aponta a generalização dos discursos individuais, para gerar um pensamento coletivo, de modo teórico e indireto. A expressão empírica do pensamento coletivo não aparece diretamente como um discurso da realidade.

Para a construção do Discurso do Sujeito Coletivo, são trabalhados os dados com três figuras metodológicas. $O$ tratamento dos dados com essas figuras permite a análise do discurso completo do indivíduo. O leitor de uma pesquisa, cujos dados foram analisados com esse método, terá conhecimento de toda fala do entrevistado e até a possibilidade de fazer uma nova interpretação destes, com outros referenciais, sem comprometer a validade científica da original. 
O início da construção do DSC é a identificação nos discursos das três figuras metodológicas: Expressões-Chave (ECH), Idéias Centrais (IC) e Ancoragem (AC).

Expressões-Chave - São trechos do discurso que revelam a essência do depoimento do sujeito entrevistado. Segundo os autores, as ECHs são a matéria-prima para a construção dos Discursos do Sujeito Coletivo. O critério para a seleção correta das Expressões-Chave é descartar o que é irrelevante, isto é, o que não responde à questão investigada, selecionando apenas a essência do pensamento tal como aparece no discurso. Deve ser identificado de modo a possibilitar o leitor a julgar a pertinência ou não da seleção e da tradução dos depoimentos, comparando o trecho selecionado com a integralidade do discurso e as afirmativas sob forma de idéias centrais e ancoragens.

Idéias Centrais - Trata-se de uma expressão lingüística que revela de maneira concisa e fidedigna o sentido de cada um dos discursos analisados. Não é uma interpretação do sentido, mas uma descrição do sentido de um depoimento ou de um conjunto de depoimentos.

Ancoragem - É a expressão lingüística que dá apoio à ECH, manifestando uma dada teoria, ideologia ou crença. De modo geral, é encontrada em quase todos os discursos, uma vez que eles são originários de pressupostos, conceitos, teorias ou hipóteses. Ela pode ser entendida como uma sustentação do saber empírico, assim como o referencial teórico está para a produção científica. Há discursos em que AC apresenta-se de maneira clara e em outras de forma genérica, quando o pesquisador corre o risco de construir / atribuir de maneira arbitrária àquilo que acredita ser a ancoragem.

A elaboração do Discurso do Sujeito Coletivo é uma agregação de trechos isolados de depoimentos de modo a formar um todo discursivo coerente, em que cada um dos depoentes se reconheça como constituinte desse todo e o todo constituído por depoente. É preciso fazer uso de muita coerência ao fazer essa agregação. Outros princípios básicos a considerar na elaboração do DSC são: posicionamento próprio, tipos de distinção entre os DSCs e a produção de uma "artificialidade natural" (Lefèvre, Lefèvre, 2003). 
O discurso elaborado deve expressar posicionamentos distintos, originais e específicos frente ao tema que está sendo pesquisado.

Uma resposta pode dar origem a mais de um DSC. Quando isso acontece, o pesquisador deverá fazer uma distinção, podendo usar um dos critérios para essa distinção: diferença/antagonismo ou complementaridade. Quando são antagônicos, é obrigatória sua apresentação em separado, quando complementares, o modo de apresentação vai depender do pesquisador de querer resultados mais detalhados ou mais genéricos.

Produção de uma "artificialidade natural" - É a maneira de construir e apresentar o discurso como se fosse proferido por uma só pessoa. Para isso, devem-se retirar particularidades, como uma determinada doença de uma única pessoa, o que autor chama de "limpar" o texto. A construção do DSC requer 0 aproveitamento de todas as idéias presentes nos depoimentos, para que a figura (DSC) fique completa e quando há "peças" iguais ou repetidas, escolhe-se apenas uma.

A descrição do DSC deve expressar o que determinada população ou grupo pensa sobre um dado tema. As pessoas são entrevistadas individualmente por pesquisadores ou por seus colaboradores. Também há a possibilidade de se elaborar um DSC sobre dados registrados em jornais e revistas. Mas nesta pesquisa, foi elaborado a partir da expressão verbal dos sujeitos. Ele possibilita a consideração do tema/problema por vários aspectos, tendo três grandes níveis de consideração: descritivo, interpretativo e evolutivo (Lefèvre, Lefèvre, 2003).

O nível descritivo restringe-se apenas à apresentação das representações presentes na população ou grupo, como meio informativo. Por exemplo: a pesquisa com os enfermeiros do oeste do Estado do Paraná, sobre o que pensam da Reforma Psiquiátrica, apresenta três discursos:

a) Uma proposta que visa a melhoria da qualidade de vida dos pacientes.

b) Há lentidão na implantação da Reforma Psiquiátrica.

c) A Reforma Psiquiátrica está sendo levada a sério.

O nível interpretativo apresenta os DSCs acompanhados de análise e interpretação do pesquisador, sendo que a qualidade do estudo do tema dependerá de fatores relacionados ao pesquisador, tais como: a escolha de 
um referencial teórico adequado, sua criatividade e capacidade de expressão. Por exemplo: a percepção dos enfermeiros de que há lentidão na implantação da Reforma Psiquiátrica pode estar relacionada ao fato de os gestores terem demonstrado pouco empenho em investir na contratação e qualificação de profissionais e a região não ter ainda uma cobertura satisfatória de serviços substitutivos, previstos em projetos que deveriam ter sido concluídos em 2005.

No nível evolutivo ou programático, procura-se uma intervenção no sentido de influenciar na evolução da representação. Por exemplo: responder como proceder para agilizar a implantação da Reforma Psiquiátrica.

Para a interpretação dos DSCs, a identificação de temas significativos pode ser utilizada para nortear o estudo do tema. Por exemplo: nos DSCs dos enfermeiros sobre a Reforma Psiquiátrica, foram identificados três temas:

a) Qualidade de Vida.

b) Envolvimento profissional / social.

c) Necessidade de mudanças.

A identificação de diferentes temas geradores de significados no mesmo DSC por outro leitor ou em uma releitura do pesquisador é possível e, em alguns estudos, até desejável, sem que comprometa seu valor científico. 


\subsection{PROCEDIMENTOS}

Os procedimentos para a viabilização desta pesquisa serão expostos da seguinte forma:

a) Os relacionados aos aspectos éticos e legais.

b) Os relacionados à coleta de dados.

c) A organização dos conteúdos das entrevistas.

Para a execução da pesquisa, foi elaborado um projeto submetido ao Exame de Qualificação, conforme regulamento do Programa de PósGraduação da Escola de Enfermagem da Universidade de São Paulo, no dia 7 de dezembro de 2005. Após aprovado, este foi encaminhado ao Comitê de Ética em Pesquisa (CEP) da mesma Escola - Processo no 4962/2005/CEPEEUSP, cumprindo as normas da Comissão Nacional de Ética em Pesquisa (Conep), presentes na Resolução 196/96 do Conselho Nacional de Saúde (CNS).

O CEP emitiu parecer favorável para a realização da pesquisa em 9 de janeiro de 2006 (Anexo A). Após esses trâmites, efetuou-se o teste-piloto do instrumento da entrevista e pequenos ajustes, sem, contudo, alterar objetivos e métodos aprovados no Exame de Qualificação e na análise do CEP.

Em anexo, o Modelo do Instrumento da Entrevista (Apêndice A), Modelo da Declaração de Consentimento Livre e Esclarecido (Apêndice B).

A coleta de dados desta pesquisa foi realizada por meio da entrevista estruturada, uma das estratégias mais usuais no estudo de campo. Esse tipo de entrevista consiste em uma conversa a dois com propósitos bem definidos, sendo essa técnica caracterizada pela comunicação verbal que reforça a importância da linguagem e do significado da fala, um meio de coleta de informações sobre um determinado tema (Minayo, 1994).

A escolha por esse meio de coleta de dados foi por entender ser este o que mais favorece a elaboração do DSC. O instrumento norteador da entrevista continha quatro questões abertas que foram elaboradas de acordo 
com alguns pontos considerados relevantes pelos autores do DSC, de modo que a pergunta ideal é aquela que leva o entrevistado à produção de um discurso, responde com exatidão aquilo que o pesquisador está investigando, leva o entrevistado a responder o que acha e não o que o entrevistador tem em mente, é apropriada e perfeitamente compreensível pelo sujeito entrevistado e foi pré-testada em sujeitos equivalentes aos da pesquisa proposta (Lefèvre, Lefèvre, 2003).

Após contato com a Secretaria de Saúde Mental dos municípios, quando apresentado o projeto com a aprovação do CEP da Escola de Enfermagem da Universidade de São Paulo, obteve-se a autorização para as entrevistas com os enfermeiros em Cascavel (Anexo B), Foz do Iguaçu e em Toledo; a orientação foi contatar direto com os enfermeiros e as entrevistas foram agendadas previamente com cada um deles; por telefone, foram marcados dia, hora e local, conforme disponibilidade e preferência de cada um. Todos optaram por ser no local de trabalho e apenas uma foi na residência da entrevistada, por esta se encontrar de férias.

As entrevistas foram realizadas no período de agosto de 2006 a janeiro de 2007. O período estendeu-se por conta da previsão de abertura de mais serviços ainda em 2006, o que não ocorreu até fevereiro de 2007. Foram realizadas 13 entrevistas.

O projeto era apresentado e, após, eram feitos esclarecimentos sobre os procedimentos para a entrevista, o uso do gravador e do instrumento norteador, bem como a preservação do sigilo da identidade dos entrevistados. A seguir, era então apresentado o termo de consentimento livre e esclarecido para que fosse assinado, havendo concordância em permanecer como sujeitos da pesquisa. Todos prosseguiram e demonstraram grande interesse pelo estudo, momento em que houve um comprometimento a fazer a apresentação da pesquisa quando concluída.

As entrevistas foram realizadas nos municípios-sede das regionais de saúde da região oeste do Paraná: Foz Iguaçu, Cascavel e Toledo.

Em Foz Iguaçu, todas foram realizadas no mesmo dia, sendo duas no período da manhã e três no da tarde. Em média, tiveram uma hora de duração. Os enfermeiros foram dois do HD, uma do ambulatório de saúde 
mental, uma do Caps II e outra do Caps ad. Todos demonstraram estar envolvidos com o processo de Reforma Psiquiátrica, cientes dos problemas locais e inteirados do processo nacional.

Em Cascavel, as entrevistas ocorreram em dias diferentes e os enfermeiros foram: dois do Caps III, dois do Caps I, um do Caps ad e dois do ambulatório. Todos estavam empenhados no melhoramento dos serviços e preocupados com a visão da sociedade em relação ao processo de Reforma Psiquiátrica, principalmente a falta de informação, que pareceu ser a mais evidente.

Em Toledo, foi realizada apenas uma entrevista no Caps II, único serviço no momento da pesquisa que havia enfermeiro. A enfermeira,muito receptiva, demonstrou empenho e interesse pela causa da Reforma, apesar de ser sua primeira experiência na área e ainda não contar com parcerias. $O$ ambulatório ainda não havia contratado enfermeiro.

As entrevistas foram realizadas após apresentações pessoais, embora os enfermeiros, em sua maioria (nove dos 13 entrevistados), conhecessem a pesquisadora como colega ou professora. Em todos os encontros, os contatos foram muito agradáveis. O diálogo sobre a caminhada profissional de cada um, ou mesmo da vida familiar e social, não estava programado, aconteceu de maneira espontânea e contribuiu para que a entrevista se desenvolvesse com mais tranqüilidade; além disso, acrescentou alguns elementos para delinear o perfil dos enfermeiros atuantes nos serviços de assistência à saúde mental, tais como: motivação, experiências e expectativas.

O tratamento do conteúdo empírico foi norteado pela proposta metodológica do Discurso do Sujeito Coletivo (Lefèvre; Lefèvre, 2003), apresentado anteriormente (subitem 3.2).

As entrevistas foram ouvidas e transcritas na íntegra. A partir daí, seguiu-se a leitura atenta para a construção do texto de análise, que consiste em extrair o máximo possível das respostas, com a essência do pensamento tal como ela aparece literalmente no discurso analisado. As recomendações para este procedimento são paciência para várias leituras e não perder o foco da questão norteadora, de modo a considerar apenas o 
que responde à questão, desprezando o que for irrelevante e acessório. Com isso, foram identificadas as Expressões-Chave, figura metodológica fundamental para a elaboração do DSC.

A identificação das ECHs foi da seguinte forma: primeiro nas respostas para a questão 1 , depois para a 2 e assim sucessivamente. A seguir, a transcrição do conteúdo para o Instrumento de Análise de Discurso (IAD), na coluna ECH. Por exemplo: 
Quadro 1 - Instrumento de Análise de Discurso - Questão analisada: Como você vê a Reforma Psiquiátrica?

\begin{tabular}{|c|c|}
\hline & IDÉIAS CENTRAIS \\
\hline $\begin{array}{l}1 \text { A Reforma Psiquiátrica veio para melhorar a } \\
\text { saúde, poderia ser mais planejada. Mas é um } \\
\text { avanço para a saúde mental e qualidade de vida } \\
\text { do paciente. Em função da Reforma, foram } \\
\text { criados os serviços extra-hospitalares, que foi } \\
\text { melhor para o paciente. O internamento tem de } \\
\text { ser o último recurso. Sabe-se que tem de ser } \\
\text { tentados todos os recursos antes da internação. } \underline{A} \\
\text { reforma foi um avanço, sim, mas há muito que }\end{array}$ & $\begin{array}{l}\text { A Reforma Psiquiátrica } \\
\text { foi um avanço para a } \\
\text { saúde mental. Ela veio } \\
\text { com a finalidade de } \\
\text { melhorá-la e atendeu } \\
\text { satisfatoriamente os } \\
\text { profissionais também. }\end{array}$ \\
\hline caminhar. Foi melhor & \\
\hline $\begin{array}{l}\text { trabalhador. } \\
2 \text { Uma proposta muito inteligente, porque } \\
\text { proporciona melhor atendimento aos pacientes, } \\
\text { eles não precisam mais ficar internados, } \\
\text { trancafiados como antes para serem tratados. } \\
\text { Isso agora pode e deve ser feito em ambulatórios, } \\
\text { Caps, oficinas, mantendo e fortalecendo seu } \\
\text { vínculo com a sociedade e família. Mas está } \\
\text { havendo pouco esforço por parte dos gestores } \\
\text { em oferecer isto para todos. Aqui tem uma lista } \\
\text { enorme esperando por uma vaga. É uma } \\
\text { proposta boa, mas precisa de mais profissionais e } \\
\text { de maior apoio da sociedade e de outras áreas. }\end{array}$ & $\begin{array}{lr}\text { A Reforma Psiquiátrica é } \\
\text { uma } & \text { proposta } \\
\text { inteligente, } & \text { que } \\
\text { proporciona } & \text { melhor } \\
\text { atendimento } & \text { aos } \\
\text { pacientes. } & \end{array}$ \\
\hline $\begin{array}{l}3 \text { Eu vejo a Reforma Psiquiátrica como uma boa } \\
\text { proposta, mas falta muita coisa: mais } \\
\text { compreensão dos gestores, integração com } \\
\text { outros profissionais de saúde e de outras áreas e } \\
\text { há pouca adesão de outros profissionais. Na } \\
\text { prática, não existe muita clareza, o que dificulta, } \\
\text { sobremaneira, um tratamento adequado. }\end{array}$ & $\begin{array}{l}\text { A Reforma Psiquiátrica é } \\
\text { uma proposta boa, mas } \\
\text { faltam compreensão e } \\
\text { adesão de outros } \\
\text { profissionais, não se tem } \\
\text { muita clareza. }\end{array}$ \\
\hline
\end{tabular}


Ao serem identificadas as Expressões-Chave, novas leituras foram realizadas para extrair as Idéias Centrais que foram sublinhadas, conforme exemplo anterior. No terceiro passo, as Idéias Centrais dos conteúdos das respostas individuais foram organizadas e, a partir delas, elaborados os Discursos do Sujeito Coletivo.

Estes Discursos podem ser apresentados de várias maneiras. Neste estudo, a opção foi apresentar um quadro-síntese da organização dos conteúdos para discussão posterior, contendo a exposição das Questões Norteadoras, das Categorias dos Discursos do Sujeito Coletivo e dos Temas Geradores de Significação identificados. Por exemplo:

Quadro 2 - Categorias internas 1

\begin{tabular}{|c|c|c|}
\hline $\begin{array}{c}\text { QUESTÃO } \\
\text { NORTEADORA }\end{array}$ & $\begin{array}{l}\text { CATEGORIAS DO } \\
\text { DISCURSO DO SUJEITO } \\
\text { COLETIVO }\end{array}$ & $\begin{array}{c}\text { TEMAS } \\
\text { GERADORES DE } \\
\text { SIGNIFICAÇÃO }\end{array}$ \\
\hline $\begin{array}{l}1 \text { Como você vê a } \\
\text { Reforma } \\
\text { Psiquiátrica? Fale } \\
\text { sobre o que sabe e o } \\
\text { que acha. }\end{array}$ & $\begin{array}{l}\text { DSC } 1 \text { Uma proposta que } \\
\text { visa a melhoria da qualidade } \\
\text { de vida dos pacientes. } \\
\text { DSC } 2 \text { Ela está sendo } \\
\text { levada a sério. } \\
\text { DSC } 3 \text { Não são todos os } \\
\text { profissionais de saúde que } \\
\text { estão integrados no } \\
\text { processo desta Reforma. } \\
\text { DSC } 4 \text { A sociedade sabe } \\
\text { pouco sobre o processo de } \\
\text { Reforma Psiquiátrica. } \\
\text { DSC } 5 \text { Há lentidão na } \\
\text { implantação desta Reforma. } \\
\text { DSC } 6 \text { A administração } \\
\text { precisa mudar a maneira de } \\
\text { conduzir o processo de } \\
\text { Reforma. }\end{array}$ & $\begin{array}{l}\text { c. Necessidade de } \\
\text { mudança na } \\
\text { maneira de conduzir } \\
\text { o processo }\end{array}$ \\
\hline
\end{tabular}


O quadro-síntese de cada questão será seguido da apresentação de seus respectivos Discursos do Sujeito Coletivo e temas.

Os conteúdos das quatro questões da entrevista junto aos enfermeiros deram origem a 16 Discursos do Sujeito Coletivo, nos quais foram identificados oito temas geradores de significação: qualidade de vida, envolvimento profissional/social, necessidade de mudanças no processo de implantação, estruturação dos serviços, cuidado de enfermagem, família e o processo terapêutico, recursos humanos nos serviços de saúde mental e quadro evolutivo dos pacientes.

Os temas constituem a base para a análise e discussão dos DSCs com o referencial teórico. 


\section{APRESENTAÇÃO DA PESQUISA DE CAMPO}

\subsection{CENÁRIO DA PESQUISA}

A pesquisa foi realizada na região oeste do Estado do Paraná, a qual possui uma área de 2290859 hectares, o equivalente a 11,5\% da área do Estado, com aproximadamente 1,5 milhão de habitantes, distribuídos em 52 municípios e três microrregiões de saúde das 22 em que está dividido o Estado. Situa-se em Foz Iguaçu a 9 ${ }^{\text {a }}$ Regional, em Cascavel a 10 ${ }^{\mathrm{a}}$ Regional e em Toledo a $20^{\underline{a}}$, locais onde estão inseridos serviços de assistência à saúde mental que atendem toda a região, razão pela qual a investigação foi realizada nessas três cidades.

A localização distante da região leste, por onde foram iniciados a colonização e o desenvolvimento do Estado, associada à carência de infraestrutura contribuíram para que a região oeste se mantivesse inexplorada por muito tempo, sendo a última fronteira a ser ocupada do Estado.

Uma das medidas que impulsionou a ocupação e a exploração desta região foi a criação do Departamento Administrativo do Oeste, na década de 1940 (Paraná, 2005). A partir de então, chegaram agricultores de origens alemã e italiana provenientes do Rio Grande do Sul e de Santa Catarina em busca de terras férteis, além de colonos liberados da cafeicultura do norte do Estado e que, gradativamente, era substituída pelo cultivo de outras lavouras e, principalmente, pela pecuária.

Segundo Magalhães (2003), a integração do oeste só avançou no final da década de 1950, quando houve os primeiros esforços para a implantação de um sistema viário que agilizou a produção de excedentes para a comercialização. Pela boa qualidade do solo e experiência dos produtores, a agricultura teve um avanço significativo, contribuindo para a expansão dinâmica do comércio. Núcleos urbanos formaram-se para dar suporte à agricultura em expansão.

Foi um período de crescimento acelerado da população na região oeste paranaense, chegando, em 1970, a aproximadamente 750 mil habitantes, a maioria concentrada na área rural. 
A partir dessa década, a agricultura da região ganha novo impulso com a introdução de tecnologias avançadas de cultivo, diminuindo o uso de mão-de-obra. Foi quando se intensificou o processo de urbanização, estimulado também pela construção do megaprojeto da Usina Hidrelétrica de Itaipu, caracterizando-a como uma região de intensa atração migratória.

A população urbana que, em 1970, era uma das menores do Estado, chega, em 1980, em um ritmo de crescimento que atingiu $12,5 \%$ ao ano, o dobro da média paranaense. Em 2000, alcançou 82\%. Apesar desse crescimento urbano, a região oeste permanece com uma das mais elevadas proporções de população rural do Estado do Paraná (Paraná, 2005b).

Entretanto, constata-se que a transformação pela implementação das atividades agrícolas na região tem causado uma migração significativa da população rural para os meios urbanos e para fora da região (Paraná, 2005b). Concomitante ao processo migratório, as mudanças no comportamento reprodutivo e no perfil de mortalidade da população ocasionaram um declínio no crescimento populacional da região.

Os municípios apresentam diferenças marcantes entre si, sobretudo as variáveis demográficas, já que os níveis de fecundidade e mortalidade não diminuíram na mesma proporção em todos os municípios. Em alguns, o declínio ficou pouco evidenciado.

Os serviços de assistência em saúde mental existentes nessa região são: um Hospital-Dia, dois Centros de Atenção Psicossocial (Caps II), um Caps III, um Caps infantil, dois Caps álcool droga, três ambulatórios, três residências terapêuticas e um hospital psiquiátrico.

As microrregiões são compostas por um conjunto de municípios, sendo um deles a sede de uma Secretaria Regional de Saúde, órgão administrativo do Estado que atua de forma intermediária junto aos municípios. É por meio dessas secretarias que o Estado desempenha as funções de apoio, cooperação técnica e investimentos nos consórcios intermunicipais de saúde, bem como o controle dos serviços de saúde da região.

A 9를 Regional de Saúde, com sede em Foz do Iguaçu, foi a primeira da região. Sua área de abrangência é composta por nove municípios, com uma população de 441499 habitantes (IBGE, 2006). 
Foz Iguaçu, sede da 9a Regional de Saúde, é um município situado no extremo oeste do Paraná a $640 \mathrm{~km}$ da capital e faz fronteira com o Paraguai. Foi fundado em 10/6/1914, com uma extensa área de abrangência, e incluía Cascavel e Toledo com seus retrospectivos distritos. Em 2006, a população era aproximadamente de 309113 mil habitantes e é considerada uma das cidades mais multiculturais do Brasil.

$\mathrm{Na}$ economia, as principais fontes de renda são o turismo e a geração de energia elétrica, bem como o comércio de produtos importados. A cidade é famosa por suas atrações turísticas, congregando turistas do Brasil e do mundo, tais como: as Cataratas do Iguaçu, Parque Nacional do Iguaçu Patrimônio Mundial da Humanidade -, a Hidroelétrica Binacional de Itaipu - a maior do mundo -, o Marco das Três Fronteiras (Brasil, Argentina e Paraguai), a Ponte Internacional da Amizade, ligando Brasil e Paraguai e o Parque das Aves, com aproximadamente 900 aves de 150 espécies.

Diversos grupos étnicos de tamanho expressivo, de diversas partes do mundo, podem ser encontrados na cidade. Os principais grupos étnicos de Foz Iguaçu são: italianos, alemães, libaneses, argentinos, paraguaios, chineses, ucranianos e japoneses.

$\mathrm{Na}$ área de Educação, Foz do Iguaçu destaca-se pela oferta de cursos superiores. Atualmente, conta com um campus da Universidade Estadual do Oeste do Paraná, que, entre outros, tem o curso de Enfermagem, também oferecido por uma das faculdades particulares das cinco existentes.

$\mathrm{Na}$ área de Saúde Mental tem um Hospital-Dia, um ambulatório, um Centro de Atenção Psicossocial álcool e droga e um Caps II - ainda não registra leitos psiquiátricos em hospital geral.

A 10aㅡ Regional de Saúde, com sede no município de Cascavel, é a que possui maior área de abrangência da região e uma das maiores microrregiões de saúde do Estado, composta por 25 municípios e uma população de 464696 habitantes em 2006 (IBGE, 2006).

Cascavel foi a cidade escolhida para a coleta de dados, dentre as outras, por ser a de maior representatividade da região e sede da microrregião de saúde. Nela estão situados os serviços de assistência à saúde mental, que atendem os outros municípios por meio do consórcio municipal de saúde. 
O município de Cascavel está localizado a $520 \mathrm{~km}$ da capital; foi fundado em 14 de dezembro de 1952, possui uma área de $20658 \mathrm{~km}^{2}$ e sua população estimada é de 284083 habitantes, sendo a maioria concentrada na área urbana. A cidade foi fundada por colonos sulistas que chegaram à região por volta da década de 1930, quando o ciclo da madeira atraiu grande número de famílias de Santa Catarina e Rio Grande do Sul e, em especial, colonos poloneses, alemães e italianos, que, juntos, formaram a base populacional da cidade.

Hoje, Cascavel é considerada a capital do oeste paranaense, um dos maiores pólos econômicos do Paraná. Sua economia está centrada na agropecuária, avicultura, suinocultura e ovinocultura. Na agricultura, é responsável por $26 \%$ da produção de grãos (milho, soja, arroz, algodão e feijão) do Estado.

Cascavel realiza vários eventos de repercussão nacional, sendo o de maior destaque o Show Rural Coopavel e a Expovel. Além da economia agropecuária, a cidade possui um dos maiores centros médicos da região, destacando-se as especialidades de gastroenterologia e ginecologia, além da realização de videocirurgias avançadas. A oftalmologia de Cascavel também é referência em cirurgias de catarata, glaucoma, retina e vítreo, recebendo pacientes de toda a região.

$\mathrm{Na}$ área de saúde mental, Cascavel tornou-se referência de toda região, quando tinha a assistência centrada no hospital psiquiátrico extinto em outubro de 2003. Atualmente, possui um ambulatório, um Caps III, um Caps i, um Caps ad, três residências terapêuticas e uma unidade de internação no hospital universitário. Além disso, possui um pólo universitário com sete instituições de Ensino Superior, sendo uma pública estadual - a Universidade Estadual do Oeste do Paraná (Unioeste), que tem cinco cursos da área de saúde, sendo o de Enfermagem o pioneiro, com 27 anos de fundação. As outras instituições também oferecem vários cursos da área de Saúde, inclusive mais três de Enfermagem.

Todas essas instituições de Ensino Superior atendem uma população de cerca de 20 mil habitantes, uma parcela significativa de jovens vindos de outras cidades e Estados. 
Vale ressaltar que esta população provocou algumas alterações no panorama da cidade, de modo especial na área de construção civil, que teve de investir na construção de moradias próprias ao estilo dos estudantes. Também no comércio e nos eventos culturais e de lazer houve necessidade de ajustes à nova demanda.

A sociedade cascavelense apresenta manifestações das culturas italiana, alemã, espanhola e polonesas. Dos emigrantes de Santa Catarina e Rio Grande do Sul, são conservados os hábitos alimentares, como o churrasco e a roda de chimarrão. Uma outra característica marcante da cidade, assim como na maioria das cidades brasileiras, é a religiosidade, predominando os cristãos do catolicismo. A cidade tem dois seminários para formação de padres e líderes comunitários e é sede de uma das arquidioceses.

Essa religiosidade também é expressa nas obras do artista plástico Dirceu Rosa, que se estabeleceu na cidade há mais de três décadas. Suas obras podem ser encontradas nas igrejas da cidade, praças e na sua casa, local de exposição permanente. Sua obra de maior evidência é a imagem da padroeira da cidade - Nossa Senhora da Aparecida, entre duas mãos, esculpidas em cimento na Praça da Catedral, na Avenida Brasil.

A $20^{\text {a }}$ Regional, com sede em Toledo, é composta por 18 municípios e 325210 habitantes; é a microrregião que possui maior número de municípios com população abaixo de dez mil habitantes (IBGE, 2006), menos serviços substitutivos na área de Saúde Mental, tem um ambulatório e um Caps II e, ainda, um hospital psiquiátrico, com modelo clássico de assistência em um dos municípios, Marechal Cândido Rondon. No momento da pesquisa, não havia oferta de leitos psiquiátricos em hospital geral.

O município de Toledo foi fundado em 1951. Na época, havia apenas mais cinco na região oeste: Foz Iguaçu, Cascavel, Guaíra e Guaraniaçu. Surgiu quando a Industrial Madeireira e Colonizadora Rio Paraná S/A MARIPÁ começou a explorar uma área de terra adquirida dos ingleses. A atividade inicial era a exploração de madeira para comercialização com a Argentina e o Uruguai.

O desenvolvimento de Toledo deu-se de forma acelerada, inicialmente em torno das comunidades agrícolas. Entre 1960 e 1970, a modernização agrícola implementou as atividades do campo, atraindo 
muitos migrantes para a região vindos do Rio Grande do Sul e de Santa Catarina, em sua maioria descendentes de italianos e alemães.

A monocultura e a concentração de propriedades contribuíram para a aceleração da urbanização. A economia do município antes era centrada na agricultura, suinocultura e avicultura eram apenas atividades complementares, mas, atualmente, é referência nacional e sustenta uma das maiores indústrias nacionais de produtos alimentícios, a Sadia.

$\mathrm{Na}$ área de ensino destacam-se, por seus dois campus universitários públicos, a Universidade Estadual do Oeste do Paraná e a Universidade Tecnológica Federal do Paraná (UTFPR), além de mais duas universidades particulares e uma faculdade.

Toledo também se destaca por ser morada de personagens reconhecidos nacionalmente nos esportes automobilísticos e na ginástica rítmica. É famosa por suas festas gastronômicas, sendo as principais: a Festa Nacional do Porco no Rolete, a Festa do Peixe, Bruderfest, tipicamente alemã e a Ipirangafest, que promove a divulgação das atividades e produtos da comunidade.

\subsection{SUJEITOS DA PESQUISA}

Os sujeitos da pesquisa foram 13 profissionais enfermeiros atuantes nos serviços de assistência à saúde mental nos três municípios-sede das microrregiões que estão implantando os serviços de assistência à saúde mental: Cascavel, Foz do Iguaçu e Toledo.

Quatro enfermeiros, na faixa etária de 25 a 30 anos, tinham, em média, dois anos de graduação; três estavam no seu primeiro emprego, um concluíra Especialização e o outro cursava Mestrado. Seis enfermeiros, na faixa etária de 31 a 40 anos, tinham entre oito a 12 anos de Graduação; dois possuíam especialização na área de Saúde Mental, três já trabalharam em hospital psiquiátrico e dois estavam no primeiro emprego na área de Saúde Mental. Os três enfermeiros na faixa etária de 41 a 50 anos possuem uma 
caminhada de mais de 10 anos na área de Saúde Mental; duas têm Especialização e um Mestrado, uma com experiência em serviços no interior de São Paulo.

\subsection{DISCURSOS DO SUJEITO COLETIVO}

Os Discursos do Sujeito Coletivo estão apresentados precedidos por um quadro-síntese da organização dos conteúdos; "Categorias Internas" indicando a questão geradora do discurso, as categorias dos DSCs e os temas identificados como geradores de significação.

Quadro 3 - Categorias Internas 2

\begin{tabular}{|c|c|c|}
\hline $\begin{array}{c}\text { QUESTÃO } \\
\text { NORTEADORA }\end{array}$ & $\begin{array}{c}\text { CATEGORIA DO DISCURSO DO } \\
\text { SUJEITO COLETIVO }\end{array}$ & $\begin{array}{c}\text { TEMAS } \\
\text { GERADORES DE } \\
\text { SIGNIFICAÇÃO }\end{array}$ \\
\hline $\begin{array}{l}1 \text { Como você } \\
\text { vê a Reforma } \\
\text { Psiquiátrica? }\end{array}$ & 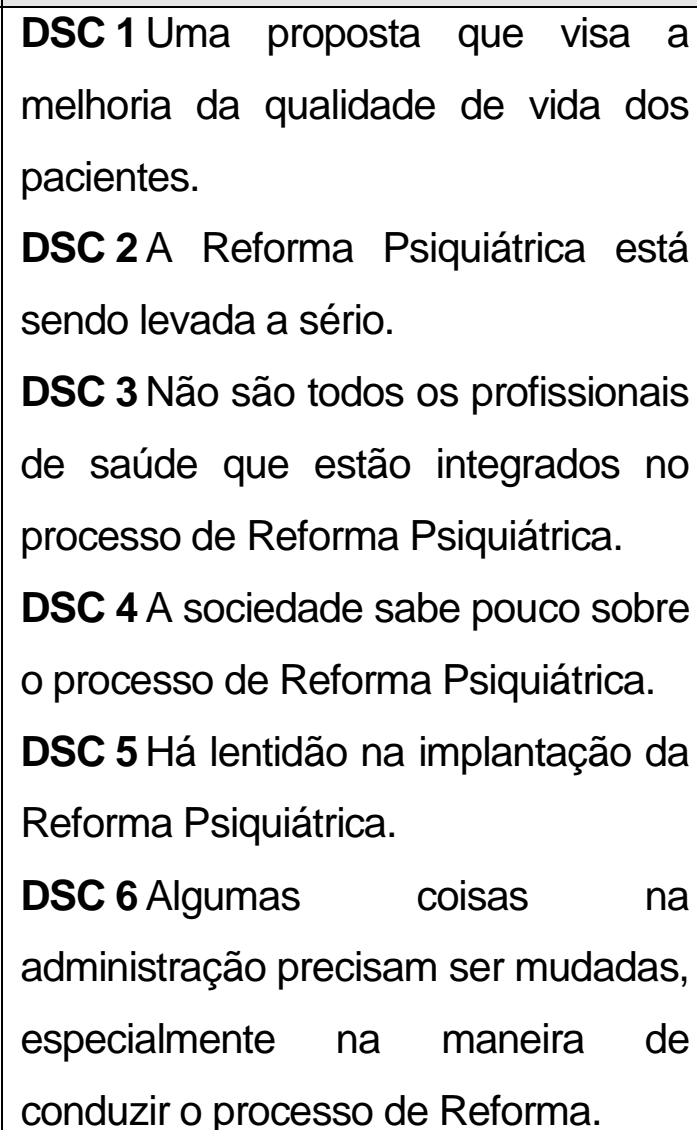 & $\begin{array}{l}1 \text { Qualidade de } \\
\text { vida } \\
2 \text { Envolvimento } \\
\text { profissional/socia } \\
\text { I } \\
3 \text { Necessidade } \\
\text { de mudança na } \\
\text { administração do } \\
\text { processo }\end{array}$ \\
\hline
\end{tabular}




\section{Primeiro Discurso do Sujeito Coletivo}

\section{- Uma proposta que visa a melhoria da qualidade de vida dos pacientes.}

A Reforma Psiquiátrica traz um novo modelo de assistência, hoje regulamentado por lei, cuja característica principal é a desospitalização, tanto que o SUS não paga mais internações prolongadas. A Reforma trouxe outros tipos de serviços assistenciais, ambulatórios, Caps e oficinas, mantendo e fortalecendo seu vínculo com a sociedade e família. Acho que é uma proposta inteligente, veio mesmo para mudar o que estava acontecendo, é uma proposta de modificação da assistência que visa a melhoria da qualidade de vida dos pacientes. É uma boa proposta, porque proporciona e exige melhor atendimento aos pacientes.

A Reforma Psiquiátrica veio para inovar o serviço assistencial, mostrar que toda pessoa portadora de doença mental é capaz de viver fora da instituição, porque é seu direito viver com a sociedade. Eu vejo com bons olhos esta transformação, como estava não existia recuperação. Hoje, existem pacientes que sequer sabiam o que calçavam ou vestiam, estão agora se vestindo e se alimentando adequadamente sem que precise de pessoal para lhes dizer a hora de comer, dormir e se banhar. Neste modelo, eles se tornaram mais independentes.

Houve uma mudança de pensamento, trouxe uma nova visão da doença mental, uma nova forma de ver e tratar a saúde mental. Os pacientes não precisam mais ficar necessariamente trancafiados em hospitais, que mais pareciam um hospício. Nós trabalhamos em um modelo que era insuficiente, ineficaz e crônico. Talvez fora mais iatrogênico do que benéfico às pessoas, mas, até então, era a única opção.

Um dos aspectos importantes que a Reforma Psiquiátrica trouxe foi o Centro de Atenção Psicossocial Infantil; as crianças não tinham este tipo de assistência. A maioria das pessoas tinha o seu diagnóstico só quando se tornavam adultas. A Reforma trouxe esta possibilidade e a colocação dos adultos novamente na sociedade. 
É uma proposta bem planejada e correta de trabalhar com as pessoas doentes mentais, porque manda que as escutemos e isso faz muito bem a elas, sentem-se respeitadas como todas as outras. Não é só uma questão de humanização da assistência, emas sim uma proposta de reconhecimento do doente mental como cidadão de direito.

Houve um grande avanço na assistência e na qualidade de vida destas pessoas. Foi o melhor para os pacientes e o profissional, é algo que funciona. É claro que existem críticas, mas com a Reforma Psiquiátrica ganham tanto os pacientes como os profissionais. Eu acredito que a Reforma veio para ficar e sou $100 \%$ a favor dela. É uma proposta de prevenção e tratamento sem exclusão.

\section{$\underline{\text { Segundo Discurso do Sujeito Coletivo }}$}

\section{- A Reforma Psiquiátrica está sendo levada a sério?}

Parece que o Ministério da Saúde tem levado a sério a Reforma Psiquiátrica, tanto que não encontrávamos dificuldades em fazer contato direto com o pessoal que estava à frente desta política. Eles têm uma boa intencionalidade. A coordenação daqui está criando serviços preconizados pela Reforma, fazendo o movimento de volta dos pacientes de contrareferência com o Programa de Saúde da Família, está fazendo uma articulação diferente.

A maioria dos enfermeiros com os quais tenho trabalhado tem mostrado que entende a Reforma e que sente que há mais a ser transformado. Mas, sabe-se que depende muito dos gestores, cada região apresentará "a carinha" dos seus gestores, da resposta que eles forem capazes de dar. 
Terceiro Discurso do Sujeito Coletivo

\section{- Não são todos profissionais de saúde que estão integrados no processo da Reforma Psiquiátrica.}

Há falta de integração com outros profissionais; na prática, muitos não têm muita clareza, dificultando a realização de um tratamento adequado. Alguns deles sequer sabem o que é. Há pacientes sendo atendidos por médicos e colegas, sendo medicados e tratados fora da proposta da Reforma Psiquiátrica, não encaminham o paciente nem orientam a família. Esta falta de conhecimento atrasa e dificulta a concretização da Reforma Psiquiátrica.

É preciso integração, faltam medidas que promovam isso e também entendimento dos profissionais de saúde geral a respeito da Reforma Psiquiátrica. Neste sentido, tem de se trabalhar muito com divulgação, discussão entre os profissionais para que haja esta integração.

As Unidades Básicas de Saúde, médicos, enfermeiros, toda equipe de saúde, deveriam buscar mais conhecimento sobre o processo da Reforma, enquanto não estiver claro para a equipe de saúde, continuará sendo difícil para a sociedade aceitar este novo modelo. As escolas deveriam dar mais ênfase para a disciplina de Enfermagem Psiquiátrica.

Quando eu estava na faculdade, as discussões estavam começando, então vim aprender fora da escola. Mas hoje, este Modelo é uma realidade, é lei e há enfermeiros recém-formados que não têm muito entendimento sobre a assistência e os serviços substitutivos. Conheço psiquiatras, médicos jovens com as mesmas idéias do modelo antigo, pautando o tratamento na medicação e hospitalização.

Portanto, há necessidade de mais profissionais e maior apoio da sociedade. Em Foz, a maior força do Movimento da Reforma Psiquiátrica está com a associação das famílias e usuários, mais do que com os responsáveis dos serviços. 


\section{Quarto Discurso do Sujeito Coletivo}

\section{- A sociedade sabe pouco sobre o processo da Reforma Psiquiátrica.}

A Reforma Psiquiátrica é pouco conhecida aqui no Paraná, é algo muito novo ainda, vai melhorar a partir do momento que se começar a falar mais sobre a Reforma, a sociedade pouco conhece. A mídia não tem explorado o tema, falam mais quando descobrem algum serviço maltratando pessoas e tratando-as de maneira desumana, aí aparece como um escândalo e isto sensibiliza as pessoas, mas de forma momentânea.

Aqui poucos sabem da existência do Caps. Muitos parentes acham que se trata de previdência social - se vamos garantir auxílio financeiro, aposentadoria ou mesmo arranjar trabalho. Nós podemos orientar e auxiliar, mas o objetivo é tratar as pessoas no sentido de estabelecer seu equilíbrio e controle da doença, de maneira que elas consigam melhorar sua interação com a família e a sua comunidade.

\section{Quinto Discurso do Sujeito Coletivo}

\section{- Há lentidão na implantação da Reforma Psiquiátrica.}

A Reforma Psiquiátrica no Brasil e, principalmente, no Paraná anda a passos lentos. Outros Estados já estão com um trabalho estruturado, mais avançado neste processo por terem começado antes. Afinal, a discussão sobre os hospitais psiquiátricos no Brasil começou há uns 20 anos.

Nos grandes centros como São Paulo, Rio de Janeiro, Porto Alegre e Minas Gerais, a Reforma Psiquiátrica está se expandindo. Nós percebemos as dificuldades nas regiões menores.

No ambulatório, o trabalho é realizado com uma visão clínica, ele se resume na consulta psiquiátrica. Na nossa cidade, nunca se viu uma prática de saúde mental, até então, que seguisse os princípios que a Reforma 
Psiquiátrica vem propondo. Não sei detalhar como ocorreu todo o processo, mas sei que foi demorado; em outros Estados, este tipo de trabalho já está estruturado há tempos.

Aqui o movimento está começando. Mas, mediante encontros, conversas, sabe-se que não está acontecendo em todos os lugares da região. Em Cascavel, por exemplo, o Caps ad e o Caps III foram criados há poucos meses, o de Foz há dois anos. Eu vim de serviços que já estão com 10 anos de Caps.

\section{Sexto Discurso do Sujeito Coletivo}

\section{- A administração precisa mudar a maneira de conduzir o processo da Reforma Psiquiátrica.}

A Reforma poderia ser mais planejada. Quais serviços alternativos serão criados para atender os pacientes? Faltou mais organização neste sentido, faltou sentar, rever a questão da rede. Houve o fechamento do hospital antes da estruturação dos serviços substitutivos. Toda rede foi implantada às pressas.

Falta muito ainda. A Reforma Psiquiátrica requer a implantação de Caps, oficinas, residências. Mas há pouca compreensão por parte dos gestores e não está havendo esforço para oferecer esta assistência para todas as pessoas que precisam. Aqui tem uma lista enorme de pacientes esperando vaga.

A saúde mental recebe pouca atenção e investimentos, tem cidade na nossa região que é referência de assistência e tem apenas um Caps, outras até têm os serviços, mas todos trabalham com equipe mínima e uma longa lista de espera. 


\subsubsection{Primeiro tema: qualidade de vida}

A preocupação maior do ser humano, desde os primórdios de sua existência, era pela expectativa do tempo de vida. Com o avanço da ciência, as necessidades humanas ficaram mais elaboradas, não basta sobreviver, a expectativa era tornar a vida o melhor possível.

No mundo contemporâneo, há um cenário de múltiplas possibilidades em todas as áreas: alimentação, vestuário, habitação, lazer, promoção à saúde, prevenção e tratamento de doenças. São recursos que implementam a existência, proporcionando maior conforto e prazer.

No entanto, os recursos capazes de melhorar a vida das pessoas não estão ao alcance de todos, ora são restringidos por seu alto custo, ora pelas limitações físicas e de saúde. Além destes dois fatores fortemente influenciáveis na qualidade de vida das pessoas, há ainda o fator cultural, e é nele que se percebe estar a relação com a doença mental afetando a qualidade de vida de seus portadores.

A cultura da ordem social baniu o louco da sociedade e o destituiu de seus direitos. A proteção concedida a eles tirava sua liberdade de escolha, de onde e com quem morar, o que vestir e o que comer. $O$ tratamento acentuava suas limitações, empobrecia suas vidas e seus sonhos e ideais passaram a ser percebidos como delírios.

O modelo de assistência asilar, como já comprovado, deixou muitas pessoas em condições subumanas de vida. A Reforma Psiquiátrica traz um novo modelo de assistência, que prevê práticas inovadoras, que ofereça, além do controle da doença, a possibilidade de resgate das potencialidades do ser humano de sonhar e realizar. A assistência deve estar comprometida com a promoção de vida (Merhy, 2007). Neste sentido, ela vem acompanhada por respeito ao doente mental como um cidadão de direitos humanos e civis.

Os DSCs dão ênfase aos aspectos da Reforma Psiquiátrica relacionados à mudança do estilo de vida dos pacientes, embora sem mencionar o termo reabilitação psicossocial; os enfermeiros demonstram 
estarem sensíveis e atentos às mudanças do cotidiano dos pacientes, valorizando a participação deles na família e na sociedade de forma mais independente.

A Reforma Psiquiátrica é percebida como uma proposta positiva pelos enfermeiros, não por ter diminuído os custos ou controlar melhor as crises ou garantir a oferta de medicamentos nas UBSs, mas "porque trouxe uma nova visão da doença mental, uma nova forma de tratar os pacientes; eles não precisam mais ficar trancafiados em hospitais, é uma proposta que visa a melhoria da qualidade de vida deles. A Reforma Psiquiátrica veio para inovar a assistência, mostrar que toda pessoa, portadora de doença mental é capaz de viver fora da instituição, porque é seu direito viver com a sociedade."

Este DSC pode ser considerado como um dos argumentos de maior solidez e beleza em favor da Reforma Psiquiátrica, porque evidencia um sentimento ético e respeitoso ao paciente.

"Não é só uma questão de humanização da assistência, é uma proposta de reconhecimento do doente mental como cidadão de direitos". Esta fala evidencia que os enfermeiros têm compreensão do modelo psicossocial proposto pela Reforma Psiquiátrica e compartilham dos mesmos objetivos. Com experiência de trabalho no modelo asilar, eles declaram:

"A gente trabalhava em um modelo que era insuficiente, ineficaz e crônico. A Reforma Psiquiátrica foi o melhor que aconteceu para os pacientes e profissionais". Esta fala revela que a Reforma Psiquiátrica deu novo significado ao trabalho de enfermagem, evidenciando ter se tornado mais gratificante.

A Reforma Psiquiátrica é um processo que vem acontecendo de acordo com a adesão de seu novo paradigma de assistência à saúde mental e à própria doença. Torna-se necessária a criação de espaço para a discussão sobre o tema, espaço não só nos âmbitos acadêmico e profissional, mas também nos vários segmentos da sociedade.

A qualidade de vida de inúmeras pessoas depende de como vai ser conduzido este processo, de quanto deste discurso vai se fazer presente nas práticas assistenciais, enfim, do grau de comprometimento e da resistência em trabalhar com as adversidades. 


\subsubsection{Segundo tema: envolvimento profissional / social}

Este tema que os DSCs da primeira questão nos apontam é o envolvimento de seus atores com o processo de Reforma Psiquiátrica. Todo processo de mudança precisa contar com a compreensão de seus objetivos pelos que fazem parte do contexto a ser mudado e que estes sejam percebidos como valores significativos. Não é tarefa fácil conseguir isso.

A Reforma Psiquiátrica é uma proposta ousada, que não se restringe a mudanças técnicas, seria simples se assim o fosse. Ela apresenta uma visão diferente de algo conceituado há muito tempo, conceitos sedimentados em um saber que foi um dia considerado um avanço, assim como se apresenta hoje o seu processo.

Há de se empregar tempo no trabalho de desconstrução de um modelo assistencial que, para muitos, significa segurança e proteção aos pacientes e familiares. Por isso, o empenho na criação de espaços para a discussão da assistência à saúde mental tem de se intensificar. O DSC denuncia a falta de integração entre profissionais como uma das causas da dificuldade de aceitação da sociedade ao novo modelo.

Parece que a resistência de muitos profissionais em se integrar, se envolver com a causa desta Reforma está relacionada ao pouco entendimento dos objetivos da proposta. O que sabem ainda não é suficiente para perceberem a significância dos objetivos da proposta para a qualidade de vida dos pacientes.

A psiquiatria evidenciou a doença e colocou o sujeito entre parênteses para melhor se ocupar dela. Basaglia (1982) propõe o inverso: a doença deve ser colocada entre parênteses, não em sinal de negação da mesma, mas para que o sujeito tome o lugar de prioridade da atenção e do cuidado. Isso ainda não é compreendido por muitos profissionais da área, é o que se constatou no DSC: "Conheço psiquiatras, médicos jovens pautando o tratamento na medicação e hospitalização". 
"As Unidades Básicas de Saúde - médicos, enfermeiros e toda a equipe de saúde - deveriam buscar mais conhecimento deste processo de Reforma Psiquiátrica". Compartilha-se com a idéia do DSC, no entanto, acredita-se que a iniciativa deve partir da equipe de saúde mental; o diálogo sobre a Reforma Psiquiátrica na comunidade deve fazer parte do cotidiano dos profissionais que atuam nos serviços assistenciais.

As medidas que a divulgação das propostas da Reforma Psiquiátrica promove, é uma concepção diferente sobre a doença mental e assistência, que precisam alcançar a sociedade como um todo e não se restringir às escolas e aos grupos de familiares dos pacientes. A reabilitação psicossocial acontece quando a sociedade está preparada para receber o paciente como um cidadão recuperado, com limitações, mas capaz. E quem, senão o profissional de saúde, vai tornar isso possível?

Nos DSC alusivo à não-integração, ao não-engajamento de todos os profissionais da área de saúde no processo de Reforma Psiquiátrica e pouco conhecimento da sociedade sobre o mesmo, foram citados dois órgãos que, no decorrer da história, têm influenciado fortemente na formação da opinião pública e, conseqüentemente, nas transformações sociais, são eles: as escolas e a mídia.

As escolas têm responsabilidade na formação de uma nova mentalidade e nas inovações técnicas profissionais. $O$ meio acadêmico é 0 espaço privilegiado para o debate das idéias e avaliação da prática cotidiana e as implicações em seu contexto. Entende-se que as idéias relacionadas a recursos técnicos são mais facilmente expostas, discutidas, assimiladas e descartadas. Quando a questão envolve conceitos, crenças, a disponibilidade para o debate é, por vezes, bloqueada. Mudanças de concepções não acontecem do dia para a noite, e o ponto de partida são todos: trabalhadores, usuários e familiares (Prandoni, Padilha e Spricigo, 2006).

Sobre a doença mental, há conceitos milenares que fazem parte da concepção de vida de muitas pessoas; a aversão, a piedade, a indiferença para com as pessoas doentes não são percebidas como problemas a serem resolvidos ou mesmo expostos. Afinal, elas não faziam parte de seu ambiente social. A maioria dos enfermeiros só teve seu primeiro contato com 
uma pessoa em sofrimento psíquico no momento dos estágios, o mesmo ocorre com outros profissionais. Fora da área de saúde, há pessoas que nunca tiveram uma aproximação com o este tipo de doente.

É neste contexto que está o desafio das escolas, em formar profissionais com potencial de transformar esta realidade. Não há aqui a intenção de análise dos currículos escolares ou mesmo dos planos de ensino, mas o endosso ao DSC; "as escolas deveriam dar mais ênfase para a disciplina de Enfermagem Psiquiátrica e Saúde Mental'. Neste sentido, a atuação interdisciplinar, de modo que o tema Reforma Psiquiátrica não seja restrito à disciplina.

O docente da área de Saúde Mental tendo a iniciativa em criar e ampliar os espaços de apresentação e debate do processo de Reforma Psiquiátrica, assim como o profissional da assistência, junto aos serviços assistenciais estariam acelerando a divulgação do processo de Reforma Psiquiátrica, possibilitando maior conhecimento e envolvimento de mais seguimentos da sociedade.

Formar enfermeiros e instrumentá-los para atuarem nos serviços assistenciais é um desafio que vem sendo vencido para as escolas. Mas o processo é complexo, tenhamos em mente que a transformação não se fará em curto prazo. A legislação por si só não faz a Reforma Psiquiátrica. É preciso que se construa no dia-a-dia dos serviços e das instituições formadoras espaços potenciais de intercâmbio e renovação (Prandoni, Padilha e Spricigo, 2006).

Quanto à abordagem da Reforma Psiquiátrica pela mídia, ter ênfase nas denúncias de falhas dos serviços induz a uma reflexão: quando os profissionais têm procurado este meio para a educação em saúde, para a divulgação de suas atividades? Os meios de comunicação têm divulgado conteúdos, dos quais têm acesso. Fica o questionamento: Por que não possibilitar o acesso de conteúdos mais esclarecedores sobre o cotidiano dos serviços de atenção à saúde mental?

Tem-se o exemplo do Serviço de Saúde Dr. Cândido Ferreira, em Campinas, no Estado de São Paulo, que tem utilizado a mídia, o jornal, o rádio e a televisão, com o objetivo de desmistificar a loucura na sociedade, sendo importantes veículos de formação de opinião pública para a diminuição de 
preconceitos e aumento da inclusão social (Roldão e Moreira, 2007). O serviço conta com um jornalista em sua equipe e parte das atividades, da rádio, o jornal tem a participação dos usuários. É uma particularidade incomum nos serviços de assistência à saúde mental, mas que pode contribuir para que outros serviços busquem espaço nos meios de comunicação local para a integração com a sociedade.

No estudo sobre a Reforma Psiquiátrica e mídia realizado no Estado de São Paulo, foi constatado que os textos publicados no jornal estudado representam "...quase de forma fidedigna a dicotomia presente no campo da Saúde Mental." (Machado, 2004; p.490). Vale considerar que os meios de comunicação funcionam como um disparador para a reflexão e formação de opinião pública de qualquer área.

\subsubsection{Terceiro tema: necessidade de mudanças na administração do processo}

Os enfermeiros deste estudo demonstram que estão acompanhando o processo de implantação da Reforma Psiquiátrica com um olhar crítico.

Apesar do empenho dos profissionais, o desenvolvimento do projeto de Reforma Psiquiátrica na região é recente, sendo acelerado por conta do fechamento de um dos hospitais psiquiátricos em 2003, ainda há um hospital na $20^{2}$ Regional.

Com a municipalização, acreditava-se que a expansão dos serviços de saúde se daria de forma concomitante com a demanda. Para que isso acontecesse, deveria haver um planejamento, tendo como base a concepção da necessidade de substituir a assistência asilar por uma assistência na comunidade, acompanhada de uma política de investimentos de capacitação e formação de recursos humanos.

A assistência à saúde mental pede um planejamento: “...um método de trabalho que visa o estabelecimento de um conjunto de providências a serem tomadas para a situação, em que o futuro tende a ser diferente do passado." (Tonini, 2005, p. 31). 
As estratégias para o planejamento em saúde mental, segundo Amarante, devem considerar algumas características que dizem respeito à natureza do saber e da Instituição Psiquiátrica, ao conceito de desinstitucionalização e à discussão sobre a invenção de novas tecnologias de cuidado (Amarante, 2003).

A apresentação de como se configura a rede de serviços assistenciais de saúde mental na região demonstra que os municípios não têm considerado estes critérios na organização da rede de saúde. $O$ DSC revela: "...faltou mais organização, o fechamento do hospital aconteceu antes da estruturação dos serviços substitutivos, toda rede foi implantada às pressas".

A Reforma Psiquiátrica demanda uma complexidade pouco compreendida pelos gestores de saúde; com freqüência, não são profissionais de saúde nem fazem parte do quadro do funcionalismo público. Ao assumirem a função comprometidos com outras prioridades, poderiam estar negligenciando o processo de implantação da Reforma Psiquiátrica. A ausência de uma política de capacitação e formação de recursos humanos faz com que falte profissional na assistência e coloca pessoas despreparadas à frente da administração e coordenação dos serviços. Diante desta realidade, os enfermeiros sentem que há necessidade de mudar a maneira de conduzir o processo de Reforma Psiquiátrica na região. 
Quadro 4 - Categorias Internas 3

\begin{tabular}{|c|c|c|}
\hline $\begin{array}{c}\text { QUESTÃO } \\
\text { NORTEADORA }\end{array}$ & $\begin{array}{c}\text { CATEGORIAS DO DISCURSO DO } \\
\text { SUJEITO COLETIVO }\end{array}$ & $\begin{array}{c}\text { TEMAS } \\
\text { GERADORES DE } \\
\text { SIGNIFICAÇÃO }\end{array}$ \\
\hline $\begin{array}{l}\text { Como é } r \text { seu } \\
\text { dia-a-dia no } \\
\text { trabalho } \\
\text { quais as suas } \\
\text { atividades? }\end{array}$ & $\begin{array}{l}\text { DSC } 1 \text { Estamos estruturando os } \\
\text { serviços. } \\
\text { DSC } 2 \text { Temos de dar muitas } \\
\text { orientações. } \\
\text { DSC } 3 \text { Realizamos reuniões. } \\
\text { DSC } 4 \text { Fazemos a recepção do } \\
\text { paciente. } \\
\text { DSC } 5 \text { O grupo e as oficinas fazem } \\
\text { parte de todos os serviços de } \\
\text { assistência à saúde mental. }\end{array}$ & $\begin{array}{l}1 \text { Enfermeiro na } \\
\text { Organização dos } \\
\text { Serviços. } \\
2 \text { Cuidado de } \\
\text { Enfermagem nos } \\
\text { Serviços } \\
\text { Atenção } \\
\text { Psicossocial }\end{array}$ \\
\hline
\end{tabular}

\section{Primeiro Discurso do Sujeito Coletivo}

\section{- Estamos estruturando os serviços.}

Comparando com outros municípios, estamos bem estruturados, mas ainda falta muito. Como o serviço é novo, estou organizando o meu dia-adia, que está complicado, nós estamos nos estruturando com muita dificuldade. Ainda temos de discutir com a equipe sobre o papel do enfermeiro, queremos participar do plano terapêutico e acompanhar $o$ processo; estamos começando a organizar a assistência como enfermeira psiquiátrica.

Nós tivemos a preocupação junto com os professores de enfermagem psiquiátrica da Unioeste, enfermeiros dos Caps e ambulatórios de criar um grupo de estudo e pensar em sistematização da assistência de enfermagem psiquiátrica. Já temos isso estruturado e pretendemos desenvolver. Até então, estávamos trabalhando com normas externas (seguindo exemplos de serviços que conhecemos). Nos perguntamos: Como vamos trabalhar 
enquanto enfermeiros? Com quais instrumentos poderemos dar assistência e atenção integral as pessoas?

O trabalho tem de ser muito profissional, temos de elaborar o plano terapêutico para cada pessoa; estamos em um momento de estruturação e temos clareza que utilizaremos este instrumento elaborado pelo grupo para orientar a assistência, pensamos em implementar o plano assistencial, a consulta de enfermagem e o trabalho de grupo com famílias.

Como o serviço é novo, estou fazendo de tudo um pouco: muitas reuniões com a equipe, familiares e coordenadores, requisitando funcionários especialmente de enfermagem. Eu estou planejando, porque cada dia é uma coisa. Quando estiver organizado, aí sim, mas hoje o que faço todos os dias é receber pacientes.

$\underline{\text { Segundo Discurso do Sujeito Coletivo }}$

\section{- A gente tem que dar muitas orientações.}

Nós precisamos dar muitas orientações sobre os atendimentos com a Reforma Psiquiátrica, porque a população ainda fica muito centrada no hospital psiquiátrico, sente falta e ainda acha que precisa do hospital na cidade. Nosso dia-a-dia é assim, com muitas orientações para a família, o que fazer com o paciente, o que é muito difícil para a família aceitar. São orientações sobre medicação e todo o tipo de patologia.

No atendimento à família, fazemos muitas orientações sobre 0 paciente, porque eles não têm muita aceitação de que o vício seja doença, como a maioria da sociedade; falamos muito disso e sobre doenças sexualmente transmissíveis, álcool e drogas. Nós damos muitas orientações sobre medicamentos (que tem de insistir muito), prevenção de crises, alimentação, higiene e atividades sobre qualidade de vida. Também com a família, basicamente, as mesmas orientações, mais informações sobre relacionamento com o paciente; oriento sobre a doença e os tratamentos em grupo e individual, principalmente sobre a medicação. 
Com o grupo de famílias, passamos orientações sobre o tratamento do paciente e tratamos de assuntos sobre a convivência com dependentes químicos, as dificuldades que eles apresentam e que requerem ajuda, como proceder e a quem recorrer caso precisem de atendimento fora do horário de atendimento.

Como o serviço é novo, procuro divulgá-lo dando orientações, informações nos outros serviços de saúde; de maneira informal, tenho ligado para os ambulatórios e algumas Unidades Básicas de Saúde (UBS), porque a maioria não conhece o Caps. Eu estou elaborando um fôlder que descreve o Caps, explica um pouco da Reforma Psiquiátrica e informa como funciona, para distribuir nas UBSs, nos pronto atendimentos da cidade e nas escolas.

Nossas orientações são no sentido de prevenção e promoção, com ênfase no reconhecimento de sinais de surto. Às vezes, resolve com orientações e apoio psicológico.

\section{$\underline{\text { Terceiro Discurso do Sujeito Coletivo }}$}

\section{- Realizamos reuniões.}

Realizamos reuniões com pacientes e equipe, a fim de organizar e avaliar o serviço com os pacientes. Além disso, participamos de reuniões com a equipe técnica, fazemos estudo de caso e a elaboração do plano terapêutico. Temos um cronograma de oficina de trabalho, um grupo operativo onde toda a equipe trabalha; para que tudo se encaminhe bem, temos de conversar muito, fazer muitas reuniões com a equipe, familiares, pacientes e coordenadores; quando posso, participo das reuniões da escola, porque acho importante conversar com os professores. 


\section{$\underline{\text { Quarto Discurso do Sujeito Coletivo }}$}

\section{- Fazemos a recepção do paciente no serviço.}

Aqui como é ambulatório, só recebemos pacientes com consultas agendadas. É claro que acontece de aparecerem alguns sem agendar, às vezes até em surto. Então, procuramos ajudá-lo e, se for o caso, os encaminhamos.

Quando vem para o ambulatório é por encaminhamento das UBSs (na maioria) e, em geral, para o médico vem para avaliação. Eu faço uma triagem para ver se o atendimento é para o psiquiatra, psicólogo ou enfermagem, se é caso de urgência ou não, levanto histórico sobre o seu estilo de vida, o uso de medicamentos, de drogas e agendamos o atendimento para o serviço indicado.

O paciente vem com encaminhamento do ambulatório, é realizada uma entrevista, fazemos um acolhimento e uma avaliação para ver se ele é um paciente de Caps ou se o seu encaminhamento foi incorreto. É quando estudamos a indicação da regularidade dele no serviço, se vai ser intensivo, semi-intensivo ou não-intensivo; fazemos o agendamento com a psicóloga, a assistente social e a terapeuta ocupacional. Antes de fazer adesão, todos passam por estas entrevistas extensas, assim como seus familiares, coletando dados e conversando sobre a sua vida e suas queixas. Nós colocamos toda a proposta do Caps, do que seria um ambulatório contínuo, para que eles possam entender o que é a Reforma Psiquiátrica, para que ela veio e qual a diferença do modelo.

Quando fazemos o acolhimento - que consiste em entrevista, exames físico e mental -, entrevistamos também os familiares, procuramos saber sobre os seus antecedentes e é comum encontrar um que precisa não só de apoio, mas também de tratamento. Após consulta de enfermagem e entrevistas, apresentamos a área física, a equipe, os outros pacientes, o programa de atividades e o funcionamento ao serviço.

No acolhimento, que é o primeiro atendimento, avaliamos os estados mental e emocional, estando muito atentos à parte clínica, higiene e nutrição. 
Quinto Discurso do Sujeito Coletivo

\section{- O grupo e as oficinas fazem parte de todos os serviços de assistência à saúde mental.}

Para trabalhar a prevenção, reunimos o grupo de famílias, que não é formado sempre pelos mesmos familiares, porque formamos com os acompanhantes dos pacientes que estão consultando.

Nós entramos às 8 horas, saímos às 18 e acompanhamos grupos e oficinas. Temos o grupo operativo que toda equipe trabalha. Ele é um grupo de organização, de regras informativas, de discussões e de levantamento de dificuldades. Depois dele fazemos as oficinas; temos seis oficinas: sobre medicamentos, em dois grupos, um de sexualidade, um de reflexão e dois de reciclagem, com trabalho de jornal.

Do nosso dia-a-dia, farão parte: o grupo terapêutico, de educação à saúde (com temas sobre autocuidado, medicação e qualidade de vida) e o grupo para discussões sobre questões de cidadania, que serão realizadas também com as famílias.

Estes grupos são feitos para tratarmos sobre redução de danos, medicação, aids, qualidade de vida e de outros temas sugeridos por eles; trabalhamos com grupos de famílias os mesmos assuntos para que sejam participantes e possam acompanhar a evolução do paciente.

Também organizamos junto com a psicóloga os grupos terapêutico, recreativo e de educação à saúde, que tratam da higiene, alimentação, dos exercícios físicos, medicamentos e das patologias. É interessante porque eles dão sugestões de temas não-centrados em suas patologias, querem saber de hipertensão e outras.

Nas oficinas, é feito um acompanhamento e trabalhamos muito com a família, não tem ainda isso programado, mas temos conversado muito; às vezes, o grupo reúne-se formalmente uma vez ao mês e outras, não dá, aí procuramos manter o contato com eles quando vêm trazer os pacientes. Muitos ficam à espera lá fora; então, nós os temos convidado para acompanharem as atividades com os pacientes e alguns relatam que o relacionamento entre eles tem melhorado. 


\subsubsection{Primeiro tema: o enfermeiro na organização do serviço de saúde mental}

"É função dos enfermeiros, em conjunto com outros profissionais de saúde mental, reunir forças na coordenação do processo de descentralização das ações em saúde mental, estabelecendo diretrizes no campo de atuação, para nortear as ações da área, hem como divulgar modalidades terapêuticas extras hospitalares, principalmente no meio acadêmico, onde se iniciam e estabelecerm mudanças."

Buchele, 1996, p.141

Os enfermeiros tinham uma tradição de responsabilidade nas instituições e os projetos eram elaborados por administradores e médicos. O novo modelo de atenção à saúde mental tem contribuído para o aperfeiçoamento das ações em saúde mental e provocado transformações na postura profissional do enfermeiro; seu campo de atuação tem se ampliado em espaço físico e em diferentes atividades nas modalidades de serviços assistenciais.

No contexto de Reforma Psiquiátrica, o enfermeiro é integrante de uma equipe multidisciplinar, onde requer capacidade para atuar de maneira interdisciplinar, sendo co-responsável pelo plano terapêutico dos pacientes e por ações de saúde mental na comunidade. A Reforma Psiquiátrica ampliou o campo de atuação dos enfermeiros, exigindo deles mais criatividade, percepção holística de si mesmo e do social.

Ao se inserir nos serviços de atenção à saúde mental, a maioria dos enfermeiros não tem formação específica ou tinham experiência no modelo clássico. A rigidez na postura de comandar e, ao mesmo tempo, de seguir normas, rotinas de adequação e ordem é antagônica ao que se espera dele neste contexto de reforma.

O fazer em enfermagem em saúde mental requer empenho em mudar, ter abertura para o novo e o diferente. Não é um processo fácil se considerarmos que é comum haver poucos enfermeiros nos serviços tendo dificuldade de adaptação, porque dificilmente eles encontram apoio de uma parceria, tendo, portanto, de aprender sozinhos. A integração com a equipe 
nem sempre se faz de maneira tranqüila, esta também tem suas limitações e confunde as funções do enfermeiro.

Os enfermeiros preocupam-se em estabelecer um plano de atividades, como algo importante para o serviço e o próprio desempenho, quando declaram: “...ainda falta muito, temos de discutir sobre o nosso papel; pensamos de que forma vamos trabalhar enquanto enfermeiros, com que instrumento vai nortear a assistência e atenção integral às pessoas".

Convém destacar a iniciativa deles de buscarem a parceria com outros enfermeiros, como os docentes da Universidade e dos ambulatórios para a formação de um grupo de estudo, pensando em sistematização da assistência de enfermagem psiquiátrica. Toledo (2004) lembra que para se estabelecer uma sistematização da enfermagem psiquiátrica, é importante que o enfermeiro abandone muito dos pressupostos teórico-prático do modelo biomédico e preconceitos antigos e abrace um modelo mais arrojado, que the permita a visualização de seus esforços (fundamentados cientificamente) como estratégias para planejar o cuidado personalizado.

Nesse momento, é importante o cuidado de não fazer da assistência de enfermagem um "anexo" do serviço, mas sim parte de uma atenção interdisciplinar. Quando do planejamento, há de se manter o foco nas propostas da Reforma Psiquiátrica, cujo objetivo principal é a reabilitação psicossocial, o que não resulta de uma ação profissional isolada.

\subsubsection{Segundo tema: o cuidado de enfermagem nos serviços de atenção psicossocial}

O cuidado de enfermagem em saúde mental foi o segundo tema de significância que emergiu nos DSCs sobre o dia-a-dia no trabalho.

O cuidado enquanto prática profissional envolve aspectos físicos, emocionais e sociais. A história evidencia um destaque para o aspecto físico, o cuidado sendo direcionado ao corpo, no sentido de manter e/ou recuperar seu estado funcional. $\mathrm{O}$ aspecto emocional foi menos privilegiado e, talvez, o menos entendido. 
O cuidado, como descrito na história, era, a princípio, desenvolvido em âmbito privado no seio da família ou em instituições que acolhiam os desamparados, em uma relação envolta por sentimentos afetivos e caritativos. Desenvolvido por pessoas consideradas como vocacionadas para o cuidar, ele era desprovido de complexidade. Entretanto, com o desenvolvimento das ciências médicas, o cuidado passa a ser uma função profissional, transforma-se em uma atividade complexa, exigindo aprendizagem e aprimoramento (Collière, 1989).

A enfermagem tem o cuidado como uma de suas especificidades, que foi sendo aprimorado e transformado em uma atividade mais elaborada, fundada no saber científico. Nessa trajetória tecnicista, ocorreu o detrimento da valorização das manifestações dos sentimentos das pessoas em favor da atenção aos seus sinais e sintomas físicos.

As pessoas parecem ter se esquecido de que o cuidar, além de constituir uma ação, é um valor, um comportamento, uma filosofia, uma arte e ciência (Waldow, 1995). "Num contexto de crescente tecnologização do cuidado, é urgente o resgate de uma visão antropológica holística, que cuide da dor e sofrimento humano, nas suas várias dimensões." (Pessini, 2002, p.127).

A proposta da Reforma Psiquiátrica vai ao encontro dessa necessidade, que é o cerne das transformações da atenção em saúde mental, ou seja, o cuidado articulado com o contexto de vida do paciente.

Atualmente, a enfermagem em saúde mental encontra-se na busca de ressignificações do saber e do fazer (Colvero, Machado, 2000). Em tempo de transformações, com a introdução de propostas que requerem abdicação de conceitos e práticas, algumas que, por muito tempo, foram freqüentes no cotidiano dos enfermeiros atualmente surgem de forma esporádica em seus discursos, tais como: medicar, restringir, isolar e supervisionar.

Ao retornar aos discursos dos enfermeiros desse estudo, vemos a citação das seguintes atividades desenvolvidas por eles: acolhimento, recepção, orientações, trabalho de grupo, oficinas, reuniões e visitas domiciliárias. O termo acolhimento, como parte da atenção à saúde, é recente, veio se difundindo a partir da política de humanização do Governo federal; HumanizaSUS, em 2003, com o objetivo de melhorar a qualidade da 
atenção à saúde da população e motivar a participação de trabalhadores, gestores e usuários na gestão das práticas de saúde. $\mathrm{O}$ acolhimento é definido como sendo o

\begin{abstract}
...estabelecimento de uma relação solidária e de confiança entre profissionais do sistema da saúde e usuários ou potenciais usuários, sob os princípios orientadores do SUS - universalidade, integralidade e equidade (Conasems, 2005: 21).
\end{abstract}

Em São Paulo, em 2001, o acolhimento surgiu como denominação de um dos projetos da gestão de saúde do município, cujo objetivo foi tecer uma rede de confiança e solidariedade entre os cidadãos e os profissionais que atendiam no serviço de saúde pública (PMSP / SMS / $\mathrm{CRH}$, 2002). Ele foi utilizado como uma estratégia de qualificação do encontro entre profissionais de saúde e usuários e entre o sistema de saúde e a comunidade, na tentativa de melhorar a relação de produção da saúde e fortalecer o vínculo entre cidadãos e profissionais (Inojosa, 2005).

Para a referida autora, acolher significa: receber, recepcionar e aceitar o outro como sujeito de direitos e desejos e como co-responsável pela produção da saúde tanto sob uma perspectiva da atenção individual como do ponto de vista coletivo. É um processo contínuo que se inicia na recepção, envolvendo todos os profissionais, requerendo uma teoria de relações e competências profissionais complementares, comunicação, diálogo, respeito pelo outro, aceitação das diferenças, de modo a ir criando uma relação mútua de confiança.

O acolhimento não é uma triagem, é um dispositivo que vai muito além de uma simples recepção. A postura acolhedora deve ser uma característica da atuação do profissional, não pressupondo hora, local ou profissional específico para a sua realização; requer, sim, agilidade no atendimento e discernimento para avaliar a necessidade do usuário.

No estudo de Coimbra (2003), o acolhimento apresenta-se como um reorganizador do serviço de saúde, visando a melhoria na qualidade da assistência, favorecendo a relação com o usuário e ampliando a intervenção. Outros estudos (Gomes, Pinheiros 2005; Silva Jr., Mascarenhas, 2005) têm 
discutido o acolhimento nessa perspectiva, como sendo uma estratégia de reorientação da assistência à saúde, com o objetivo de alcançar o princípio da universalidade.

$\mathrm{Na}$ atenção à saúde mental, ele visa escutar a pessoa e compreender a situação de forma mais abrangente desde o primeiro contato, buscando firmar um vínculo de confiança entre a equipe e o usuário e sua família, além de proporcionar segurança, bem como torná-lo participante de seu tratamento.

$\mathrm{O}$ acolhimento pode ser realizado por qualquer um dos profissionais da equipe. Porém, na região oeste do Paraná, os enfermeiros é que têm se ocupado com mais freqüência dessa atividade, embora nem todos tenham denominado e demonstrado ter clareza desse procedimento. Assim, alguns referiram-se a certos componentes do acolhimento como orientação ou, simplesmente, recepção, ao passo que outros revelaram entendê-lo como a primeira consulta de enfermagem.

A partir da visualização do perfil profissional do grupo, que apresenta profissionais com formação e experiência na área, mas que também conta com alguns deles iniciando seu exercício profissional nos serviços de saúde mental, sem terem recebido capacitação específica, pode ser entendida essa diferença no discurso sobre algumas atividades.

A orientação, segundo Houaiss (2004), é entendida como: direção, guia ou regra. Orientar seria marcar por meio de orientação, indicar o rumo exato de algo, instruir e alertar.

Quando os enfermeiros falam que realizam "orientações" estão se referindo às informações que repassam a respeito da doença, das medidas de controle, em especial sobre o uso de medicação, o autocuidado e as informações sobre a dinâmica do serviço, sendo estas comuns a todos os pacientes. Também há atenção para as necessidades específicas e particulares do paciente e família quando detectadas na escuta destes.

Uma outra prática comum no cuidado à atenção à saúde mental é o trabalho em grupo, estratégia que os enfermeiros vêm desenvolvendo como meio de socialização e troca de experiências. No grupo, as pessoas estabelecem vínculos, compartilham suas experiências, possibilitando 
conhecimento de diferentes formas de manejo de situações comuns.

A característica do grupo é ser um todo dinâmico em movimento. $O$ que faz um conjunto ou aglomeração de pessoas tornarem-se um grupo é a presença de interesses comuns. O conhecimento de todos os membros que pode produzir uma tensão entre o perigo e um objetivo comum também faz com que as relações entre si se transformem de maneira positiva (Sartre, 1960).

O grupo na concepção de Pichon (1988) é um conjunto restrito de pessoas interligadas por constantes de tempo e espaço, com um propósito de uma tarefa, que constitui sua finalidade. Para ele, os grupos estruturamse na tríade necessidade-objetivo-tarefa e não existe grupo vínculo ou grupo sem tarefa, daí a denominação de grupo operativo, o qual é citado no discurso dos enfermeiros desse estudo: "...temos grupo operativo em que toda equipe trabalha...é um grupo de organização, de regras informativas, de discussões e de levantamento de dificuldades."

Os enfermeiros têm conduzido esse tipo de grupo seguindo os três passos preconizados por Pichon (1988): abertura, desenvolvimento e encerramento. A abertura, seguindo o modelo, é uma exposição teórica sobre um determinado assunto, realizada pelo coordenador, seguida pela elaboração do tema, sendo essa parte um disparador para o seu desenvolvimento, discussão do problema (tarefa), encerramento. Esta última etapa, também feita pelo coordenador, é uma apresentação, uma devolução do que foi expresso da assimilação do conteúdo informado, com a incorporação do conteúdo latente (Lopez, Manzolli, 1996). "A vivência grupal é uma forma ativa de se relacionar e cada pessoa num grupo dispõe de um patrimônio de experiências para serem compartilhadas." (Tatagiba, Filártiga, 2001, p.14).

As experiências que o grupo proporciona às pessoas podem ser de fortalecimento ou fragilidade. O grupo constituído nos serviços de saúde deve ter uma organização que possibilite segurança para trocas significativas entre os seus membros, estabelecendo uma relação de vínculos e os enfermeiros se encontram nesses grupos como o principal motivador. 
Uma relação de vínculos (solidários e afetivos e de compromisso) é um processo que acontece quando há motivação revestida de direcionalidade, orientação e determinação mútua (Lopez, Manzolli, 1996). As autoras enfatizam que o grupo pichoniano visa em seu conjunto a saúde mental.

Um outro tipo de grupo mencionado no discurso foi o de espera. Essa denominação surgiu em um Centro de Saúde Mental, em Buenos Aires, quando da necessidade de atenção a uma parte significativa de adolescentes que ficaram fora dos grupos terapêuticos constituídos devido à grande demanda (Kornblit, Rascovsky, 1970).

No contexto da atenção psicossocial da região do estudo, trata-se de um grupo de integrantes não-fixos, podendo ser integrantes também de outros grupos. Freqüentemente, são pessoas, familiares ou cuidadores que vêm acompanhar os usuários em atendimento, consultas e outras atividades do serviço, que ficam horas na sala de espera. Os enfermeiros têm preenchido esse tempo com atividades relacionadas à educação à saúde, identificação das dificuldades dos familiares com o tratamento do paciente e outras questões de interesse comum.

Também vem sendo motivada a criação de grupos de auto-ajuda, monitorado pelo enfermeiro, para os familiares em especial os dos dependentes químicos. Este grupo é o que propicia a troca de auxílio e apoio entre pessoas que vivenciam problemas comuns relacionados a eventos e situações traumáticas (Barros, 1997).

Em qualquer uma das modalidades de grupo, os enfermeiros devem trabalhar de forma que todos os seus componentes tenham espaço de expressão. O grupo não deve ser apenas um meio passivo de transmissão de orientações, informações ou lições, mas sim para a expressão do saber, das expectativas e necessidades de seus membros,

Uma outra atividade que tem preenchido o cotidiano dos enfermeiros nos serviços é o acompanhamento das oficinas, junto com o terapeuta ocupacional e os monitores. As oficinas expressivas, que trabalham com a manifestação de sentimentos, relacionamento pessoal e autocuidado são as mais assumidas pelos enfermeiros, bem como as culturais $e$ as de conhecimentos gerais, onde são trabalhados temas sugeridos pelos usuários. 
As oficinas geradoras de renda têm ainda pouca representatividade econômica, trabalhando com artesanato (bordados, tricô, crochê, pinturas, jardinagem, material de reciclagem e marcenaria), sendo que o retorno financeiro tem sido apenas para sua própria manutenção.

Ao retornar ao discurso dos enfermeiros, o cotidiano nos serviços é bastante complexo. As atividades desenvolvidas são coerentes com a proposta da Reforma Psiquiátrica. Contudo, grande parte daquelas desenvolvidas no espaço da instituição apresenta pouca repercussão na rede social. O distanciamento da sociedade e dos outros profissionais de saúde é apontado pelo grupo no discurso anterior como um fator que dificulta o processo de Reforma.

Embora tendo essa percepção, os enfermeiros não têm desempenhado com freqüência ações que conduzam a aproximação com outras equipes de saúde e a comunidade. Um dos fatores que tem contribuído para essa situação é o número reduzido de profissionais na equipe para o atendimento de inúmeros pacientes. Mesmo com uma nova visão da atenção à saúde mental e a assistência psiquiátrica, este olhar fica limitado ao local de trabalho, aos profissionais da área de saúde mental, sendo que as discussões não se estendem para outros profissionais de saúde.

É preciso estar atento ao constante risco que corremos de promover uma reforma superficial ou pseudodesinstitucionalização, na medida em que são mantidos os dispositivos de segregação internalizados, compondo uma subjetividade manicomial. 
Quadro 5 - Categorias Internas 4

\begin{tabular}{|c|c|c|}
\hline $\begin{array}{c}\text { QUESTÃO } \\
\text { NORTEADORA }\end{array}$ & $\begin{array}{c}\text { CATEGORIA DOS } \\
\text { DISCURSOS DO SUJEITO } \\
\text { COLETIVO }\end{array}$ & $\begin{array}{c}\text { TEMA } \\
\text { GERADORES DE } \\
\text { SIGNIFICAÇÃO }\end{array}$ \\
\hline $\begin{array}{lr}\text { Quais } & \text { as } \\
\text { dificuldades que } \\
\text { você encontra no } \\
\text { dia-a-dia do seu } \\
\text { trabalho? }\end{array}$ & $\begin{array}{l}\text { DSC } 1 \text { A participação da família } \\
\text { no processo terapêutico. } \\
\text { DSC } 2 \text { A falta de profissionais. } \\
\text { DSC } 3 \text { A estruturação da rede. } \\
\text { DSC } 4 \text { A atuação dos gestores } \\
\text { e coordenadores } \\
\text { DSC } 5 \text { O desempenho de } \\
\text { profissionais despreparados. } \\
\text { DSC } 6 \text { A instabilidade dos } \\
\text { pacientes }\end{array}$ & $\begin{array}{l}1 \text { Família e o } \\
\text { processo terapêutico. } \\
2 \text { Recursos } \\
\text { humanos na atenção } \\
\text { psicossocial } \\
3 \text { A evolução dos } \\
\text { pacientes }\end{array}$ \\
\hline
\end{tabular}

\section{Primeiro Discurso do Sujeito Coletivo}

\section{- A participação da família no processo terapêutico.}

A participação da família, principalmente pelo pouco entendimento que tem da doença e freqüência no serviço, dificulta algumas atividades, por exemplo, a formação de um grupo, marcamos e eles não vêm. Então, temos de falar com eles quando vêm trazer os pacientes para a consulta $e$ aproveitar este momento para fazer orientações.

Um outro ponto negativo é o pouco entendimento e aceitação que eles têm com o paciente, fazendo comprometer-se pouco com o tratamento. Eles colaboram pouco, estão cansados, não confiam no paciente nem incentivam, e isto é sério, fica difícil. A maior dificuldade é o trabalho com a família. Eles têm vindo muito ao Caps ou Hospital-Dia, visando apenas conseguir o benefício financeiro e acabam reforçando as limitações do paciente à sua condição de doente. Às vezes, mentem em relação à evolução dele, forçam a internação, não dando os medicamentos corretamente. 
Às vezes, é difícil conseguir a adesão dos pais ao tratamento, especialmente quanto à medicação, eles têm pouco comprometimento, acham que o médico, o atendimento semanal têm de dar conta; não compreendem a importância de freqüentar o Caps, acham que é só tomar o remédio. Não incentivam as crianças para participação de atividades na comunidade nem na escola. O tratamento fica demorado também em função da não-participação dos pais.

Como o serviço é novo, é difícil para eles entenderem o trabalho do Caps, querem saber por que não funciona à noite... Enfim, a idéia do hospital ainda é muito presente. Isso é a maior dificuldade no dia-a-dia, mas sabemos que eles fazem isso porque estão preocupados e querem apressar o atendimento. Eles vêm com muita expectativa, às vezes de que vamos dar emprego, mudar o auxílio doença para aposentadoria... Ainda tem muito para eles entenderem e muito mais para aprendermos e descobrir como acelerar este processo.

\section{Segundo Discurso do Sujeito Coletivo}

\section{- A falta de profissionais.}

Uma outra dificuldade é a falta de médicos, enfermeiros, assistentes sociais e psicólogos terapeutas, causando um acúmulo de serviço. Você não consegue fazer o serviço andar como deveria, nem sempre podemos dar a devida atenção porque a equipe é pequena para o número de pacientes que tem aqui. Tem mais de sete mil pessoas para três médicos, tem pacientes que esperam até três meses por uma consulta. Isso é a maior dificuldade, a demanda é grande mesmo, não há disponibilidade de mais tempo, temos um grande número de pacientes e trabalhamos com uma equipe mínima.

É difícil encontrar tempo para organizar as atividades, tenho as oficinas, se quiser preparar alguma coisa diferente, é serviço de casa, porque aqui não dá tempo. Quando saímos do grupo vamos para a oficina, depois chegando do almoço tem outra. Temos pouco tempo para o número 
de atividades que tentamos fazer, são muitas para um pequeno número de profissionais, trabalhamos com apenas um auxiliar de enfermagem, é um grupo de apoio muito pequeno e isto nos massacrou. Tem dificultado muito, temos trabalhado o máximo possível, mas está difícil respirar, suprir as necessidades, existe uma demanda muito grande no município.

Falta tempo para estar ampliando e implementando as atividades, pois a equipe é pequena. É difícil trabalhar com poucos profissionais e sem outro enfermeiro. Os serviços estão sempre trabalhando com um maior número de pacientes e uma equipe mínima de profissionais. Nós estamos dando conta, mas à custa de muito esforço e disponibilidade dos profissionais que são bons e têm capacitação para fazer o melhor.

\section{$\underline{\text { Terceiro Discurso do Sujeito Coletivo }}$}

\section{- A estruturação da rede.}

Nós percebemos que aconteceu tudo na última hora, foram criados vários serviços ao mesmo tempo, mas não o suficiente, a rede ainda não está estruturada como deveria. Os serviços ainda não têm uma interação satisfatória entre si nem com as outras áreas. A rede ainda tem muitas lacunas, não há leitos psiquiátricos, faltam vagas nos Caps, principalmente para adolescentes usuários de álcool e drogas, pois não temos para onde encaminhar, nosso Caps ad só oferece vagas para adultos. Você tem de falar não a todo o momento para as Unidades Básicas de Saúde (UBSs), para familiar e paciente que nos procuram.

É muito difícil lidar com esta demanda reprimida que só tende a aumentar, porque não temos previsão de quando teremos essas vagas. Foz comporta um Caps III, estamos com 309 mil habitantes. É uma grande dificuldade lidar com isso, sinto carência de suporte, a instituição precisa estar aberta e, de certo modo, lutamos pelo fechamento dos hospitais e estamos empenhados em consolidar as propostas da Reforma Psiquiátrica e essas falhas na rede comprometem a aceitação do novo modelo. 


\section{Quarto Discurso do Sujeito Coletivo}

\section{- A atuação dos gestores e coordenação.}

Hoje, a maior dificuldade é a convivência com uma coordenação que mantém uma postura autoritária, não deixa acontecer a troca na equipe; por problemas pessoais, impede a dinâmica do trabalho. A não-clareza e o nãoreconhecimento do papel da enfermagem, por parte da coordenação e sua visão tecnicista, quer trazer práticas do hospício que não tem nada a ver com as propostas da Reforma Psiquiátrica; com certeza, esta é a maior dificuldade, porque, com relação às dificuldades relacionadas aos pacientes, estamos preparados para lidar.

O desconhecimento e a falta de compreensão do novo modelo de assistência, por parte dos gestores e algumas coordenações, fazem com que vejam os serviços de saúde mentais como caros, porque envolve múltiplos profissionais para atenderem um número menor de pacientes daqueles que estavam costumados a ver nos ambulatórios antigos. Não reconhecem a diferença, o valor que tem a escuta do paciente, para a qualidade da assistência. A saúde mental é vista pela maioria dos gestores como uma ilha. A presença de coordenadores e gestores que não têm claro as propostas da Reforma Psiquiátrica tem atrasado este processo.

\section{$\underline{\text { Quinto Discurso do Sujeito Coletivo }}$}

\section{- As dificuldades relacionadas com os profissionais.}

Nós encontramos muita dificuldade com alguns profissionais, creio que pela própria formação. Ás vezes, chegam sem ter idéia do que é, de como vai ser o serviço, aí você investe, torce e quando acha que está bem, eles desistem, pedem transferência, e isto acontece com freqüência, é muito ruim. Um outro aspecto com a equipe é o problema com os funcionários de 
nível médio, que chegam com uma visão de que o paciente é louco e perigoso; eles têm uma formação voltada para o atendimento hospitalar, esses conceitos ainda estão impregnados em muitos.

As escolas não estão formando auxiliares e enfermeiros para 0 atendimento em saúde mental, eles chegam nos serviços sem saber como abordar o paciente, às vezes sem saber quais atividades fazer em um Caps. Este é um desafio constante, porque há muita rotatividade desse pessoal e dos enfermeiros, porque prestam concurso sem esperar vir trabalhar em um serviço para doentes mentais.

É difícil a relação dos profissionais, sobretudo dos enfermeiros de outros serviços de saúde mental; sinto que têm muita resistência em se reunir para estudar, discutir as questões. Os familiares são exemplos, tem uma associação forte aqui e os enfermeiros ainda não conseguiram formar um grupo de estudo.

\section{Sexto Discurso do Sujeito Coletivo}

\section{- A instabilidade dos pacientes.}

A maior dificuldade é lidar com a instabilidade dos doentes mentais, conseguir a assiduidade deles nas atividades planejadas; eles são muito instáveis e os daqui ainda mais, porque somam os fatores inerentes da adolescência e de justiça, alguns deles já tiveram envolvimento com o tráfico.

Um dia, eles estão participativos, comunicativos, confiantes, pedem apoio, então você planeja as atividades, introduz ou exclui algo do plano terapêutico, e no outro, estão agressivos ou apáticos e desconfiados. No ambulatório é lidar com a angústia dos pacientes na espera da consulta, principalmente os de primeiro atendimento. Eles chegam esperando um imediatismo e não é assim, passam pela avaliação antes de terem a consulta médica agendada e isso demora; temos de trabalhar com esta angústia deles, estar conversando, orientando e, quando possível, avaliando de novo para ver se é o caso de antecipar a consulta, passando-o na frente 
de outros, o que é outro desgaste para todos terem de adiar uma consulta.

Um outro momento difícil é o período da pré-alta, porque você vê o paciente recuperado, mas emocionalmente ele está sofrendo, sente insegurança em voltar para casa, a escola e a sociedade. Nós sabemos que é difícil, sabemos como ainda são vistos e tratados pela sociedade e pouco podemos fazer para minimizar isso. Eles são carentes de tudo, é um problema social, é difícil lidar com essa frustração, que passa ser nossa também.

Nos discursos sobre as dificuldades do dia-a-dia do trabalho, elencamos três temas geradores de significância: a família e o processo terapêutico, a estruturação e organização da rede e a evolução dos pacientes.

\subsubsection{Primeiro tema: a família e o processo terapêutico}

A família é uma instituição formada por duas ou mais pessoas, com vínculos fundados no afeto, apego e parentesco, podendo não estar presentes os três tipos de vínculos.

Há várias composições de família, sendo que a mais valorizada e difundida e que ainda predomina é a família nuclear ou comum: pai, mãe e filhos, formada a partir de um contrato social entre o casal.

As características da família vêm se modificando no decorrer dos tempos tanto na sua constituição quanto na natureza de suas relações. Elas podem ser formadas sem um contrato social (casamento) prévio entre o casal, assim como os papéis de pai, mãe e filhos já não são tão delimitados.

As funções da família, ao longo do tempo, não têm sofrido muitas alterações, embora, com uma rede de apoio e interferências diferentes e nem sempre facilitadoras, estas continuem sendo: identificação social de seus integrantes, reprodução, produção e consumo de bens (alimentação, vestuário, brinquedos e remédios), educação proteção e socialização das crianças e formação do adolescente. Para a educação e a saúde de seus integrantes, os pais contam com o apoio da rede social (Ariès, 1979). 
Para Bussab (2000), não existe sociedade humana na qual o parentesco seja considerado irrelevante; no entanto, são avaliados por diversos tipos de informações: quem cresce junto, quem se parece com quem, quem compartilha valores e experiências e a quem se apega.

A convivência por meio de trocas contingentes e afetuosas contribui para a constituição e desenvolvimento da família.

Esses apontamentos chamam a atenção para a necessidade de ampliarmos o olhar quando vislumbramos alcançar a família, convidam a considerações sobre o ambiente contemporâneo em que estão sendo constituídas. Na atenção à saúde mental, busca-se a família com o intuito de formar uma parceria para o plano terapêutico. A busca deve ser por aqueles com os quais o paciente tenha vinculação afetiva mais profunda, pois estas sugerem existência de apego recíproco, o que é essencial aos processos de coesão, tendo ou não parentesco consangüíneo.

O primeiro núcleo social da pessoa é constituído pela família e os enfermeiros enquanto promotores de saúde precisam identificar possíveis contribuições para o tratamento da pessoa em sofrimento psíquico. O núcleo familiar consiste de uma rede social mais próxima e disponível, onde se evidenciam aspectos emocionais intra e intersubjetivos (Saraceno, 2001).

Assim, pode se considerar a família como um dos mais importantes componentes da rede social, quando contemplada no contexto do plano terapêutico. "A família dos pacientes psiquiátricos têm sido há muito tempo uma inquietação para os profissionais da saúde..." (Lopez, Manzolli, 1996; p.19). Mas nem sempre esta expectativa é correspondida.

Ao retornar ao discurso dos enfermeiros desse estudo, encontrou-se a seguinte fala em alusão aos familiares: "Eles colaboram pouco, estão cansados, não confiam no paciente, não incentivam, é sério, (...) é difícil conseguir a adesão dos pais ao tratamento, eles têm pouco comprometimento".

Diversos fatores podem ocasionar essa postura, pois quando a doença mental surge, mudanças profundas acontecem na vida familiar, as alterações são tanto de caráter objetivo como subjetivo (Santos, Silva, 2002). Percebeu-se o decréscimo no padrão socioeconômico da família, 
ocasionado pela diminuição de renda e aumento de gastos. No cotidiano, isso influencia nos hábitos de se alimentar, de se vestir, de lazer e na convivência, muitas vezes, com o preconceito do grupo social.

Entre as mudanças de ordem subjetiva estão: a negação, tristeza, maior preocupação e inconformismo com a nova realidade, dificultando a compreensão da doença e a interação com os profissionais de saúde e o paciente. A convivência da família com um dos seus membros com doença mental constitui um desafio.

Estudos em outras localidades (Colvero, 2002; Santos, Silva, 2002; Reco, Galera, 2004), entre outros, têm identificado nas famílias um cotidiano conturbado e com a queda na qualidade de vida, marcado por mudanças de comportamento, como: alguém deixou de trabalhar e alguém começou a beber.

Ao retornar para os discursos dos enfermeiros desse estudo sobre a família, foram identificados: pouca aceitação, pouco entendimento e comprometimento, também a percepção deles de que os familiares estão cansados e preocupados em apressar o atendimento ao paciente, mas que, ao mesmo tempo, as expectativas em relação ao serviço são equivocadas.

Diante desses dados, evidencia-se a necessidade de inclusão da família nos programas de saúde, não apenas para colaborar no plano terapêutico do paciente, mas para receber auxílio na convivência do seu cotidiano conturbado. Um auxílio por meio de acompanhamento para atender tanto as necessidades objetivas como informações sobre a doença, tratamento, recuperação, controle e direitos dos doentes mentais, como as necessidades subjetivas: sentimentos e vivências de impotência, desamparo, raiva e culpa (Santos, Silva, 2002).

Os enfermeiros precisam buscar capacitação para melhor lidarem com a família, no sentido de intensificar o vínculo com o serviço e melhorar as relações com o paciente, bem como "...de poder criar na família, um espaço de partilha e de celebração da vida." (Moreno, Alencastre, 2002; p.101). 


\subsubsection{Segundo tema: recursos humanos na atenção psicossocial}

As transformações paradigmáticas que estão ocorrendo no campo da saúde mental pressupõem a presença de profissionais com uma postura inovadora e criativa, para desenvolverem no cotidiano práticas que concretizem a proposta do novo conceito.

Nesse cenário de transformação estão diversos atores de diferentes categorias profissionais, além dos enfermeiros, que nem sempre partilham da mesma compreensão do processo e da maneira de conduzi-lo. Os conflitos são freqüentes, comprometendo o curso das transformações; alguns destes estão relacionados com a formação acadêmica do profissional, fatores culturais e grau de comprometimento.

Em diversos estudos sobre a atuação dos enfermeiros, foi encontrada a referência do profissional como sendo uma das causas mais freqüentes de suas dificuldades, apontando: o número reduzido na composição das equipes, formação precária, pouca clareza, incompreensão, contradições entre a forma de pensar e operar, bem como a não-aderência às propostas de inovação (Hirdes, 2001; Oliveira, Alessi, 2003; Pereira, Mishima, 2007; Machado, Colvero, 2003).

Entre os profissionais citados estão: gestores, docentes, enfermeiros e outros profissionais de saúde mental e de outras áreas da saúde. No presente estudo, também se evidencia um quadro com característica semelhante à dos citados anteriormente, o que sugeriu que fosssem elencados "recursos humanos na área de saúde mental", como o segundo tema de significância, nos discursos dos enfermeiros, sobre suas dificuldades.

Os recursos humanos determinam a qualidade em qualquer processo de transformação, na atenção à saúde mental; a diferença na conjugação da proposta passa a ser comprometedora. O conhecimento elaborado a partir dos discursos permite dizer que a atuação dos gestores e coordenadores da saúde nos municípios, de alguma forma, tem limitado o avanço das transformações no campo da saúde mental. 
A limitação no processo da Reforma Psiquiátrica, provocada pelos gestores e coordenadores, seria em decorrência de uma visão de atenção à saúde mental orientada pelo modelo hospitalocêntrico. Há falta de clareza e reconhecimento da proposta a ser implantada, bem como do espaço dos enfermeiros nesse contexto, propondo, assim, algumas práticas contraditórias às preconizadas, como descrito no discurso: “...trazer práticas do hospício que não têm nada haver com as propostas da reforma psiquiátrica".

Essa configuração do quadro de gestão e coordenação de saúde é determinada por vários fatores, entre eles, a formação profissional, que, em sua maioria, não pertence à área de saúde e ao tipo de vínculo que tem com a causa, como detentores de cargo de confiança, não fazendo parte do quadro de funcionalismo público, interferindo, assim, na continuidade do processo que, freqüentemente, não é visto como prioridade.

A rede para a atenção à saúde mental na região do estudo apresenta várias lacunas, com uma dinâmica que ainda não interage de maneira satisfatória com as outras áreas. Faltam vagas nos Caps e unidades de internação nos hospitais gerais. Em um dos municípios do estudo, houve o fechamento do hospital psiquiátrico antes da implantação de serviços extrahospitalares, suficientes para atender a demanda, que, segundo o discurso dos enfermeiros, "...só tende a aumentar, porque não temos previsão de quando teremos essas vagas...", há listas de espera na maioria dos serviços.

A atuação de gestores e coordenadores reflete na qualidade da atenção dispensada à comunidade, na medida em que os investimentos se tornam reduzidos, restringido a contratação de mais profissionais e ocasionando precariedades em vários aspectos dos serviços. Em especial no trabalho das equipes que, formadas com o número mínimo de profissionais, não conseguem melhorar o plano terapêutico dos pacientes nem desenvolverem atividades externas, comprometendo, assim, a organização e o desempenho dos profissionais, de modo mais direto, dos enfermeiros.

Para a abertura dos serviços, a recomendação do MS é que se tenha, no mínimo, uma equipe composta da seguinte forma: 


\section{CAPS I}

- Um médico psiquiatra ou médico com formação em saúde mental

- Um enfermeiro

- Quatro profissionais de nível superior de outras categorias profissionais: psicólogo, assistente social, terapeuta ocupacional, pedagogo ou outro profissional necessário ao projeto terapêutico

- Seis profissionais de nível médio: técnico e/ou auxiliar de enfermagem, técnico administrativo, técnico educacional e artesão

\section{CAPS II}

- Um médico psiquiatra.

- Um enfermeiro com formação em saúde mental.

- Quatro profissionais de nível superior de outras categorias profissionais: psicólogos, assistentes sociais, terapeuta ocupacional, pedagogo, professor de Educação Física ou outro profissional necessário ao projeto terapêutico.

- Seis profissionais de nível médio: técnico e/ou auxiliar de enfermagem, técnico administrativo, técnico educacional e artesão.

\section{CAPS III}

- Dois médicos psiquiatras.

- Um enfermeiro com formação em saúde mental.

- Cinco profissionais de nível superior de outras categorias profissionais: psicólogos, assistentes sociais, terapeuta ocupacional, pedagogo, professor de educação física ou outro profissional necessário ao projeto terapêutico.

- Oito profissionais de nível médio: técnico e/ou auxiliar de enfermagem, técnico administrativo, técnico educacional e artesão. 
Esse discurso demonstra o sentimento provocado nos enfermeiros em decorrência da sobrecarga do cotidiano no trabalho. Mais que o cansaço físico é a sensação de frustração em não poder dispensar uma atenção compatível com a capacidade e valores que possuem.

Um outro aspecto negativo dos recursos humanos mencionado no discurso dos enfermeiros é relacionado à formação dos técnicos tanto nos de nível médio como nos de nível superior. O que constitui mais um dificultador do cotidiano e, por vezes, frustrações quando, após um determinado período de investimento e apoio para integrá-lo na equipe, o profissional opta por uma transferência.

$\mathrm{Na}$ percepção dos enfermeiros, as escolas não estão formando profissionais para o atendimento em saúde mental, “...eles chegam aos serviços sem saber como abordar o paciente e que atividades desenvolver em um CAPS". Esta constatação deve ser considerada como um disparador para a reflexão sobre o ensino da assistência de enfermagem psiquiátrica e em saúde mental, pois os profissionais têm chegado ao campo de trabalho com uma visão crítica sobre as práticas oriundas do modelo médico, mas com pouca criatividade para desenvolver práticas compatíveis com o modelo psicossocial.

Esse quadro sugere uma aproximação mais estreita e contínua do ensino com a assistência; estudos de avaliação da disciplina de Enfermagem Psiquiátrica e de Saúde Mental têm demonstrado como aspecto negativo a carga horária da disciplina, considerada como insuficiente, pelos alunos docentes e a equipe do serviço, pois o período em que o aluno passa no estágio é curto, limitando a experiência de vivenciar e compreender toda a complexidade da prática assistencial. A permanência do aluno por um período maior nos serviços de saúde mental evidenciou o desenvolvimento de uma visão ampliada da assistência oferecida aos pacientes e seus familiares e contribuiu para a formação diferenciada do enfermeiro (Carmo Otani, Rosa, Rosa, Siqueira, 2002).

A conclusão destes estudos sugere que o desenvolvimento de projetos de ensino junto aos serviços contribuiria para o melhor desempenho do aluno, quando profissional, diminuindo ou eliminando a estranheza do enfermeiro recém-formado aos serviços assistenciais. 
No entanto, a adversidade e, por vezes, os conflitos entre o ensino na área de Saúde Mental e a assistência são também desencadeados por fatores mais complexos advindos de outros que não docentes, discentes e técnicos e o próprio contexto em que a Reforma Psiquiátrica foi introduzida.

Nesse sentido está a observação de Barros (2001) sobre a base da Reforma Psiquiátrica ser formada por um pequeno grupo de intelectuais da área da psiquiatria sobre a qual se firmou o movimento de luta, que culminou com sua implantação, mas que não representava (e ainda não representa) a concepção de toda sociedade sobre atenção ao doente mental. A constatação é de que "...o Estado propõe uma política social que a Escola não está reproduzindo." (Barros, 2001; p.172).

Com essa leitura, tornam-se compreensíveis as resistências encontradas em vários seguimentos da sociedade para a consolidação das transformações no campo da saúde mental. Vale considerar o que propõe o estudo de Barros (2001; p.174):

...que o ensino de enfermagem em saúde mental construa marcos teóricos precisos e que deles originem pressupostos da intervenção, resgatando de todas as teorias existentes o que há de positivo na construção de um sujeito social - cidadão, quer seja doente mental ou não.

\subsubsection{Terceiro tema: a evolução dos pacientes}

A evolução do quadro do paciente constitui tema de significância no discurso dos enfermeiros. A dificuldade a ele relacionada é percebida pela necessidade de mais parcerias no desenvolvimento do projeto terapêutico. Também pode ser entendida como decorrência de outros fatores já mencionados como dificultadores, tais como: a oferta de vagas para atender a demanda existente e o número de profissionais insuficiente que não permite a expansão das atividades além da instituição.

O paciente precisa de motivação para aderir ao tratamento; no seu estado de vulnerabilidade, requer atenção contínua, com acompanhamento, avaliação e orientações, em especial no início do tratamento. 
Para o enfermeiro, sem uma qualificação específica na área de saúde mental, lidar com alguns aspectos do sofrimento psíquico, como a instabilidade emocional e agitação psicomotora, é difícil e bastante desconfortável. A falta de suporte do serviço com a ausência de colegas para partilhar suas angústias e a permanência de resquícios culturais sobre a loucura tornam seu desempenho no cotidiano um grande desafio: “...de um lado a manutenção do cuidado ligado ao disciplinamento e à vigilância; por outro lado a busca de alternativas que determinem ações coparticipativas entre equipe e paciente." (Humerez,Fonzi,Cavalcante, 2000; p.43).

O momento da inserção do paciente no serviço, como no período de atendimento e no pré-alta é vivenciado pelos enfermeiros desse estudo como uma dificuldade. Os pacientes chegam ao serviço, freqüentemente, após uma longa espera pelo encaminhamento na expectativa de serem atendidos prontamente pelo psiquiatra, o que não acontece devido à grande demanda.

Aos enfermeiros do ambulatório cabe a realização da avaliação para determinar a seqüência das consultas, gerando neles um alto grau de responsabilidade pela evolução do paciente, “...quando a gente sente a necessidade de antecipar a consulta, é um desgaste para todos, porque para isso temos que adiar outra". Os enfermeiros também experienciam momentos difíceis pela espera da consulta, são eles que lidam diretamente com a angústia dos pacientes e a pressão dos familiares.

Com o paciente inserido no serviço, pensando em sua evolução, os enfermeiros desdobram-se em esforços para propiciarem uma assistência de qualidade. $O$ quadro sugere que $o$ aumento de profissionais na equipe, em especial de enfermeiros, contribuiria para uma assistência de melhor qualidade, sem provocar desgastes físico e mental nos enfermeiros, tornando o cotidiano de seu trabalho mais gratificante.

Ao se considerar a proposta de reabilitação psicossocial dos serviços de saúde mental, o período que antecede a alta do paciente provoca muitas inquietações nos enfermeiros relacionadas ao contexto dos ambientes familiar e social para qual ele vai retornar. 
É importante que o paciente encontre em seu ambiente familiar apoio e incentivo para o enfrentamento das adversidades na sociedade, pois a ausência de suporte poderá desestabilizá-lo. A preocupação dos enfermeiros aumenta quando avaliam o ambiente familiar como não sendo favorável para a inclusão social do paciente, pois isso poderá comprometer o controle da doença e causar sentimentos de rejeição e frustração.

A estrutura dos serviços não possibilita o acompanhamento da equipe aos pacientes nesse processo de reabilitação após a alta. Essa limitação os faz se sentirem, de certa forma, impotentes; é o que revelam nessa parte do discurso: "...sabemos como eles são vistos e tratados pela sociedade e muito pouco podemos fazer para minimizar isso; eles são carentes de tudo, é um problema social complicado, difícil de lidar com essa frustração que passa ser nossa também."

A importância da empatia na relação com os pacientes, da interação com outros profissionais e serviços da rede e do comprometimento dos enfermeiros na busca de espaços de atuação fora da instituição parece-nos ser o motivo deles manterem um sentimento de apego aos pacientes; de certo modo, sentem-se responsáveis pelo futuro deles, permeando aí um sentimento de "obrigação" para com eles, um desejo de onipotência para continuarem a ajudá-los.

A quais ações esse sentimento poderá levar? Talvez ao comprometimento do cuidado cotidiano no presente e uma depreciação pelo próprio desempenho; mas esse desconforto também pode se constituir em um disparador para refletirem sobre a ampliação da atenção para a sociedade, no sentido de contribuir na transformação dessa realidade, que consideram desfavorável para a reabilitação social dos pacientes.

"Oculta na roupagem metafórica palpita a essência real" (Helena Kelody). 


\section{CONSIDERAÇÕES FINAIS}

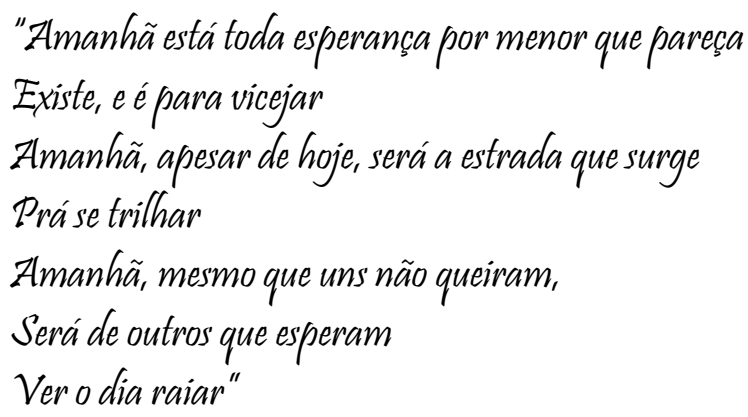

Guilherme Arantes

\section{- Reflexões sobre a trajetória da pesquisa.}

Para concluir a apresentação dessa pesquisa, retornou-se às inquietações que motivaram a realização desse estudo. Inserida em um contexto que iniciava os primeiros passos rumo às transformações propostas pela Reforma Psiquiátrica, o questionamento era: como os enfermeiros estavam experienciando esse momento e qual sua participação cotidiana no processo, levando-se em conta ser de relevância o registro desse momento para futuras avaliações e conhecimento do processo.

Nessa trajetória em busca de respostas, outros questionamentos foram se agregando, as próprias respostas apresentaram-se como disparadores dos mesmos. O objetivo aqui é que esse estudo desencadeie nos leitores novos questionamentos e reflexões, vindo somar ao referencial bibliográfico mais experiências significativas acerca da implantação do processo da Reforma Psiquiátrica dessa região.

Nesse momento, a tentativa é descrever a percepção obtida sobre o que foi encontrado, seus atores e o contexto - tentativa porque a intenção era descrever a percepção da pesquisadora. Mas como enfermeira e docente atuando na região do estudo, não foi uma tarefa fácil. Ainda que ciente de que é impossível para um pesquisador ser neutro em seu trabalho, porque não há pesquisa desinteressada (Mehry, 2005), houve momentos em que os achados causavam uma sensação de orgulho, em outros, um certo desconforto, um ímpeto (contido) de argumentar, justificar. Era a experiência 
de vivenciar o "...problema de ser além de sujeito interessado, ser também um sujeito implicado..." (Mehry, 2005, p.2) na pesquisa.

Bem, a situação descrita sem dúvida constituiu-se em um disparador para o questionamento acerca da atuação da pesquisadora enquanto docente. Questionamentos a serem respondidos em outro momento, quanto à percepção do que foi encontrado, é de um quadro interessante e instigante.

Todos os serviços de atenção psicossocial da região contavam com uma lista de espera na época da pesquisa. Observou-se que o funcionamento de todos os Caps da região era mantido pela "equipe mínima", a composição recomendada pelo Ministério da Saúde, para a abertura dos serviços. Porém, as atividades desenvolvidas atendiam a todos os pacientes de maneira igualitária, o maior déficit foi percebido na atenção dispensada à família e à comunidade; as visitas domiciliárias eram mínimas, bem como as atividades de integração com as Unidades Básicas de Saúde e até entre outros serviços de saúde mental.

O prejuízo de forma direta atingia mesmo a equipe. Em dois serviços - um Caps II e um ambulatório -, os profissionais haviam reduzido o horário de almoço e atrasado o encerramento das atividades diárias, para atenderem um número maior de pacientes. Na maioria deles, as reuniões de avaliação e programação das atividades do serviço aconteciam fora do horário de trabalho, justificando que acreditavam ser uma situação provisória e que, de alguma maneira, apresentavam uma prova da necessidade de aumentar o número de profissionais nos serviços. Nessa atitude, percebeuse um comprometimento significativo com o serviço (pacientes), talvez mais que isso, um apego e credibilidade na proposta da Reforma Psiquiátrica; "...eu acredito que a Reforma Psiquiátrica veio para ficar, sou 100\% à favor, porque proporciona melhor atendimento aos pacientes...".

Os discursos apresentam um conteúdo rico, consistente e crítico sobre a Reforma Psiquiátrica; as respostas convergiram-se em descrevê-la como um processo que possibilita a melhoria da qualidade de vida das pessoas. Embora demonstrem otimismo com a Reforma Psiquiátrica, os enfermeiros também são críticos e apontam a lentidão na implantação da 
rede na região, comparada a outras regiões do País. A Reforma Psiquiátrica vem acontecendo no Brasil de forma não-linear, mas de acordo com os recursos e vontade política dos gestores de suas regiões (Maftum, 2001).

Apesar de a Reforma Psiquiátrica estar sendo conduzida com seriedade pelo Ministério da Saúde, a administração local deveria mudar a maneira de conduzir o processo desta Reforma.

Há entre o grupo a clareza de que a Reforma Psiquiátrica se trata de uma transformação da atenção à saúde mental, que se concretizará por meio de práticas inovadoras, "...os pacientes não precisam mais ficar necessariamente internados, trancafiados em hospitais". "Uma relação terapêutica só pode ser estabelecida com o doente livre." (Basaglia, 1985, p.120).

Nesse estudo, há algo que já vem sendo encontrado e descrito em pesquisas realizadas em vários pontos do País e que consideramos ser preocupante. A alusão é para o fato de ainda permearem nos discursos dos enfermeiros inseridos no processo da Reforma Psiquiátrica alguns posicionamentos oriundos e próprios do modelo biomédico e asilar.

Esses resquícios foram identificados entre os argumentos de valorização da proposta de Reforma, com a atenção focada nos pacientes, na descrição de suas práticas e na organização da equipe. "Acho uma proposta bem planejada e correta de trabalhar com as pessoas doentes mentais, porque manda que as escutemos..." Ao defrontarmos com esse termo imperativo, recordamos de um questionamento bastante instigante, por um dos membros da banca, durante o exame de qualificação do projeto dessa pesquisa; quando apresentava nosso estranhamento pelo fato de após anos de luta pela Reforma Psiquiátrica, uma vez conquistada com a regulamentação da lei, ainda haviam profissionais que mantinham as mesmas condutas, inclusive nos serviços extra-hospitalares, ao que ele questionou: "Quando foram para esses serviços, no contrato de trabalho que assinaram, estava escrito que era para trabalharem dessa forma?" Isso se tornou uma constante inquietação durante essa pesquisa e, com certeza, continuará, nos faz lembrar que posturas são decorrentes de conceitos e valores, não de leis. 
Nós endossamos o discurso de que as escolas deveriam dar mais ênfase para a disciplina de Enfermagem Psiquiátrica e Saúde Mental, bem como outros cursos da área de saúde, intensificarem a atenção na formação de profissionais para atuarem dentro do novo paradigma.

A proposta de a atenção ser dispensada em um campo interdisciplinar é defendida como algo positivo, mas esse argumento também se mostra frágil, pois ainda há o movimento de divisão, quando a preocupação com sistematização é fragmentada; a sistematização da assistência de enfermagem, da assistência psicológica e de outras pode se configurar em uma aglomeração de áreas, onde cada uma representa um anexo dentro do serviço; isto é incoerente com a idéia de atenção do modelo biopsicossocial, que almeja que essa seja resultado de uma construção coletiva no campo da saúde mental (Torres, Amarante, 2001).

No cotidiano, junto com o discurso de transformação, ainda se realizam condutas que sedimentam mais o modelo hegemônico do que concretiza o discurso. Há uma valorização pela atenção do "médico" em detrimento da de outros profissionais da equipe, situação que causa ansiedade não apenas nos pacientes e familiares, mas também na equipe à espera pela "consulta médica". Essa situação ocorria com mais freqüência nos ambulatórios.

Nesse cenário dos serviços, as atividades assistenciais eram as que mais preenchiam o cotidiano dos enfermeiros, em apenas um serviço o enfermeiro se ocupava das atividades administrativas. Com ocupações e preocupações, o grande número de pacientes, a falta de profissionais na equipe, a estruturação do serviço, o reconhecimento de outros profissionais de saúde e da comunidade apareceram como fatores de complicações.

Uma outra percepção do grupo sobre a Reforma Psiquiátrica é de que a sociedade tem pouco conhecimento do processo. Isso poderia estar relacionado ao fato do também desconhecimento por grande parte dos profissionais de saúde, da discordância de uns e indiferença de outros, comprometendo, dificultando e atrasando as transformações da atenção à saúde mental. 
Questões que envolvem qualquer situação relacionada à loucura aparecem sendo tratadas de forma superficial por uma grande parte dos profissionais de saúde, tanto nos que declaram sua aprovação como nos que a reprovam. Há um esvaziamento de argumentos por ambas as partes para a discussão, uma cautela que vela o não-comprometimento.

Foram encontrados profissionais cuja adesão ao movimento das Reformas mais a compromete do que os que se opõem. A adesão acontece às vezes em decorrência de oportunismo; há os profissionais que aceitam as propostas de transformações por comodismo e por parecerem atualizados. Mas, na verdade, mantêm uma resistência passiva, desempenhando ações de novas modalidades de forma mecânica, até adotam algum discurso contrário às suas crenças, que se manifesta na prática cotidiana. Esses podem transformar o serviço em manicômios ao mesmo tempo em que estão proferindo discursos que fundamentam a Reforma (Bezerra, 1999). "Sem ter na mente, nem nos corações, a dimensão ética e política fundamental de qualquer proposta de superação da cultura manicomial." (Bezerra, 1999, p.138). Esse perfil encontra-se nas várias áreas que compõem o campo da saúde mental, como também entre os gestores.

O modelo asilar foi sedimentado por muito tempo; sabe-se que toda a transformação proposta pela Reforma Psiquiátrica passa por uma visão diferenciada, direcionada por uma nova concepção, que não acontece de maneira tão tranqüila. Crenças, valores e preconceitos constituem-se em verdadeiros muros (mais resistentes dos que cercavam os manicômios), que deverão ser removidos para a consolidação da Reforma Psiquiátrica.

Nessa trajetória, analisou-se

....até que ponto se quer ou se pode encarnar esses desejos não manicomiais e esses desejos de direitos humanos em nossas vidas. Ou até que ponto somente se está sendo politicamente correto abraçar essas lutas (Machado e Lavrador, 2001, p. 45-6). 
Encerra-se essa pesquisa ciente de ter registrado uma parte da história da implantação da Reforma Psiquiátrica, nessa região, em especial da atuação dos enfermeiros, suas práticas, dificuldades e expectativas, mormente a paixão e o empenho de sua maioria pela causa; contudo, a complexidade do processo requer novos estudos, sobretudo de questões aqui apresentadas. "Acreditamos que vemos a realidade assim como ela é, embora a vejamos assim como podemos." (Demo, 2001, p.65) 


\section{REFERÊNCIAS}

Agência Estadual de notícias. Saúde mental no Paraná, 2007. Disponível em: http://www.aenoticias.pr.gov/article.php?stryd=13322.

Aguiar MGG. A reinvenção do ser enfermeiro no cotidiano da Casa de Saúde Anchieta e Núcleos de Atenção Psicossocial São Paulo [dissertação]. Escola de Enfermagem, Universidade de São Paulo; 1995.

Almeida Filho NM. Universidade nova: textos críticos e esperançosos. Salvador: Editora da Universidade Federal da Bahia; 2007.

Almeida MCP, Rocha JSY. O saber de enfermagem e sua dimensão prática. São Paulo: Cortez; 1986.

Amaral MA. Atenção à saúde mental na rede básica: estudo sobre a eficácia do modelo assistencial. Rev Saúde Públ. 1997;31(3):288-95.

Amarante $\mathrm{P}$, coordenador. Archivos de saúde mental e atenção psicossocial. Rio de Janeiro: NAU Editora; 2003. A (clínica) e a reforma psiquiátrica.

Amarante $\mathrm{P}$, organizador. Loucos pela vida: a trajetória da Reforma Psiquiátrica no Brasil. Rio de Janeiro: SDE/ENSP; 1995.

Amarante $\mathrm{P}$, organizador. Psiquiatria social e reforma psiquiátrica. Rio de Janeiro: FIOCRUZ; 1994.

Amarante P. Manicômio e loucura no final do século e do milênio. In: Fernandes MI (Org.). Fim de século: ainda manicômios? São Paulo: IPUSP, 1999.

Andrade A, Bosi MLM. Mídia e subjetividade: impacto no comportamento alimentar feminino. Rev Nutr. 2003;16(1):1-10.

Appadurai A. Disjuncture and difference in the global cultural economy. Public Culture. 1990;II(2):1-24. 
Aranha e Silva AL. Enfermagem em saúde mental; a ação e o trabalho de agentes de enfermagem de nível médio no campo psicossocial [tese]. São Paulo: Escola de Enfermagem, Universidade de São Paulo; 2003.

Araújo RB, Gimeno LID, Mello RM, Ruschel EB, Benevides LS, Nichetti RC. Repercussões do fechamento da unidade de desintoxicação do hospital psiquiátrico São Pedro. Rev Psiquiatr Rio Gd Sul. 2003:25(2):1-11.

Ariès P. História social da criança e da família. Rio de Janeiro: Zahar; 1979.

Barleta C. Política estadual de saúde mental. Secretaria Estadual de Saúde Mental. [internet]. 2005. [citado 2006 jul. 25]. Disponível em:

http://www.aenoticias.pr.gov/article.php?stryd=13322.

Barleta C. Vagas no atendimento à saúde mental no Paraná. Secretaria Estadual de Saúde Mental. [internet]. 2007. [citado 2008 jan. 27]. Disponível em: http://www.aenoticias.pr.gov/article.php?stryd=13322.

Barros S. Concretizando a transformação paradigmática em saúde mental: a práxis como horizonte para a formação de novos trabalhadores [tese livredocência]. São Paulo: Escola de Enfermagem, Universidade de São Paulo; 2005.

Barros S, Pitta AMF. Desafio do fazer e formar o novo: Programa de interação docente assistencial em saúde mental USP/SES/SP. In; Congresso Nacional da Rede Unida, 3, 1997, Salvador. Anais, 1997.

Barros S. O louco, a loucura e a alienação: o ensino de enfermagem sub judice [tese]. São Paulo: Escola de Enfermagem, Universidade de São Paulo; 1996.

Basaglia F, Basaglia Ongaro F, Casagrande D, Jervis G, Jervis Coma L, Pirella $A$, et al. Considerações sobre uma experiência comunitária. In: Amarante, $\mathrm{P}$, organizador. Psiquiatria social e reforma psiquiátrica. Rio de Janeiro: FIOCRUZ; 1994. p. 11-40.

Basaglia F. A instituição negada: relato de um hospital psiquiátrico. Trad. de Heloísa Janhn. Rio de Janeiro: Graal; 1985.

Basaglia F. A psiquiatria alternativa: contra o pessimismo da razão, o otimismo da prática. São Paulo: Brasil Debates; 1982. 
Bauer M, Kunze H, Von Cranach M, Fritze J, Becker T. Psichiatric reform in Germany. Rev Acta Psych Scan. 2001;104(410):27-34.

Bertolote JM. Em busca se uma identidade para reabilitação psicossocial. In; Pitta AM. Reabilitação psicossocial no Brasil. São Paulo: Hucitec; 1996.

Bezerra B Jr. A diversidade no campo psiquiátrico: pluralidade ou fragmentação? Cadernos IPUB. 1999;14:135-40.

Bezerra-Junior B, Amarante P, organizadores. Psiquiatria sem hospício: contribuições ao estudo da reforma psiquiátrica. Rio de Janeiro: RelumeDumará; 1992.

Birman J. A cidadania tresloucada. In: Bezerra B Jr, Amarante P, organizadores. Psiquiatria sem hospício - contribuições ao estudo da reforma psiquiátrica. Rio de Janeiro: Relume-Dumará; 1992

Birman J. Psiquiatria e sociedade. J Bras de Psiquiatr. Rio de Janeiro. 1982;31(4):237-461.

Brasil, Lei n. 10.216 de 6 de abril de 2001.Dispõe sobre a proteção e os direiros das pessoas portadoras de transtornos mentais e redireciona 0 modelo assistencial em saúde mental.Diário Oficial da republica Federativa do Brasil. Senado Federal, DF.Brasília 2001

Brasil. Ministério da Saúde. Portaria n. 224, de 9 de janeiro de 1992. Estabelece as diretrizes e normas para o atendimento ambulatorial e hospitalar de Saúde Mental. Diário Oficial da União. Brasília. n. 9, 30 jan. 1992, Seção 1, p. 1167-70.

Buchele F. A enfermagem na reestruturação da assistência psiquiátrica. Rev Texto e Contexto. 1996;5(2):140-6.

Bumardo E. Reforma psiquiátrica tem lado cruel. Gazeta do Povo. 2006 mar. 27.

Burt L. Italian, psychiatric reform 20 plus years after. Rev Acta Psych Scan. 2001;104(410):41-6.

Bussab VSR. A família humana vista da perspectiva etológica: Natureza ou cultura? Rev Interação. 2000,(4):9-22. 
Campos GWS. Modelos de atenção em saúde pública: um modo mutante de fazer saúde. Rev Saúde Debate. 1992;(37):16-9.

Caplan G. Princípios de psiquiatria preventiva. Rio de Janeiro: Zahar; 1980.

Carmo DR, Machado RCBR, Otani MAP, Rosa AJS, Rosa RSL, Siqueira AC Jr. O ensino de enfermagem em saúde mental e psiquiátrica no currículo integrado dos cursos de enfermagem da faculdade de Medicina de Marília (FAMEMA) e da Universidade Estadual de Londrina. In: Anais do VII Encontro de Pesquisadores em Saúde Mental e VI Encontro de Especialistas em Enfermagem Psiquiátrica; 2002 mar. 25-28: Ribeirão Preto, BR. Rieirão Preto: EERP; 2002. p.175.

Casanova EG. O cuidado de enfermagem em unidade de internação psiquiátrica: uma transição do asilar para a reabilitação psicossocial: o familiar e o exótico [tese]. Rio de Janeiro; Escola de Enfermagem Anna Nery, Universidade federal do Rio de Janeiro; 2002.

Castel R. A instituição psiquiátrica em questão.In:Figueira AS, organizador. Sociedade e doença mental. Rio de Janeiro: Campus; 1978.

Certeau M. Giard L. Pierre M. A invenção do cotidiano: 2. morar, cozinhar. Petrópolis: Vozes; 2003.

Coimbra VCC. O acolhimento num centro de atenção psicossocial [dissertação]. Ribeirão Preto: Escola de Enfermagem, Universidade de São Paulo; 2003.

Collière MF. Promover a vida: da prática das mulheres de virtude aos cuidados de enfermagem. Lisboa: Lidel; 1989.

Colvero LA, Machado AL. Cuidado da enfermagem em saúde mental: desafio da modernidade. In: Jorge MSB, Silva WV, Oliveira FB (Org.). Saúde mental: da prática psiquiátrica asilar ao terceiro milênio. São Paulo: Lemos, 2000.

Colvero LA. Desafios da família na convivência com o doente mental: cotidiano conturbado [tese]. São Paulo: Escola de Enfermagem, Universidade de São Paulo; 2002.

Colvero LA. O significado do "ser enfermeiro" em ambulatório de saúde mental [dissertação]. São Paulo: Escola de Enfermagem, Universidade de São Paulo, 1994. 
Conasems - Conselho Nacional de Secretarias Municipais de Saúde. Relatório de gestão, Ministério da Saúde, Brasília, 2005.

Costa AC. Instituto de saúde mental do Distrito Federal. In: Pitta AM. Reabilitação psicossocial no Brasil. São Paulo: Hucitec; 1996.

Costa ACF. Direito, saúde mental e reforma psiquiátrica. In: Aranha MI (Org.). Direito sanitário e saúde pública. Brasília: Ministério da Saúde; 2004.

Covino AM, O cotidiano nos espaços de morar e habitar em saúde mental [dissertação]. São Paulo: Escola de Enfermagem, Universidade de São Paulo; 2007.

Dalmolin, BM, A trajetória da saúde mental no Brasil: da exclusão a um novo modelo. Mundo da Saúde. 2000;24(1):51-8.

Delgado PG. Palestra proferida na disciplina Evolução histórico social da assistência em saúde mental da Escola de Enfermagem, Universidade de São Paulo. São Paulo; 2005.

Demo P. Pesquisa e informação qualitativa: aportes metodológicos. Campinas: Papirus, 2001.

Desviat M. A reforma psiquiátrica. Rio de Janeiro: Fiocruz; 1999.

Dias TA, Mion J. A transição do modelo de assistência psiquiátrica em Cascavel e a influência no ensino. In: VIII Encontro de Pesquisadores em Saúde Mental e VII de Especialistas em Enfermagem Psiquiátrica; 2004 abr. Ribeirão Preto: EERP; 2004.

Dias, TA. Schneider JF, Durman S. Reabilitação Psicossocial: um espaço para o exercício da interdisciplinaridade. Rev Nursing, v.87, n. 82005.

Duarte MCR. A reabilitação psicossocial nos serviços de atenção à saúde mental: estudo entre seus pressupostos teóricos e o que se pensa e faz a respeito [dissertação]. São Paulo: Escola de Enfermagem, Universidade de São Paulo; 2005.

Espinosa, AMF. Guias práticos de enfermagem psiquiátrica. São Paulo: Ernesto Reichmann; 2000. 
Fernandes MAH. A moradia assistida: um projeto em busca do desenvolvimento humano e da cidadania na área de saúde mental [dissertação]. São Paulo: Instituto de Psicologia, Universidade de São Paulo; 2001.

Ferreira Filha MO, Silva ATMC, Lazarti R. Saúde mental e pobreza no Brasil:desafios atuais. [on line].

Disponível:WWW.consciencia.net/2003/12/12.saúde mental. Acessado 17 abril 2008.

Figueiredo AC. A ética do cuidar. In: Práticas ampliadas em saúde mental: desafios e construções do cotidiano. Cadernos IPUB. 1999;14:130-3.

Foucault M. A história da loucura na idade clássica. São Paulo: Perspectiva, 1978.

Friedman J. Global system, globalization and the parameters of the modernity. In: Mike Featherstone, Scoth Lash and Roland Peterson, organizadores. Global Modernities. Londres: Sage Publications; 1995.

Furegato AR. A conduta humana e a trajetória do ser e do fazer da enfermagem. São Paulo: Lemos; 2000.

Gattari F. Revolução molecular: pulsações políticas do desejo. São Paulo: Brasiliense; 1986.

George JB. Teoria de enfermagem: os fundamentos à prática profissional. Porto Alegre: ARTMED; 2000.

Goffman E. Manicômios, prisões e conventos. São Paulo: Perspectiva; 1974.

Goldeberg J. Cotidiano e instituição: revendo o tratamento de pessoas com transtorno mental em instituições públicas [tese]. São Paulo: Faculdade de Medicina, Universidade de São Paulo; 1998.

Gomes M, Pinheiros R. Acolhimento e vínculo:práticas de integralidade na gestão do cuidado em saúde em grandes centros. Interface [periódico na internet]. 2005 mar./ago [citado 2006 jan. 20];9(17):287-301. Disponível em: http://www.scielo.br/scielo.php?pid=S1414-

32832005000200006\&script=sci_abstract\&tlng=pt. 
Heller A. O quotidiano e a história. Rio de Janeiro: Paz e Terra; 1992.

Hirdes A. Reabilitação psicossocial: dimensões teórico-práticas do processo. Erechim: EdiFAPES; 2001.

Houaiss A. Minidicionário Houaiss da língua portuguesa. $2^{\text {a }}$. ed. Rio de Janeiro: Objetiva; 2004.

Humerez, DC, Fonzi M, Cavalcante MCG. O paciente com transtorno mental participanso do tratamento medicamentoso em unidade psiquiátrica. Rev Acta Paulista de Enfermagem. 2000.13(2):74-80.

Inojosa RM. Acolhimento: a qualificação do encontro entre profissionais de saúde e usuários. In: Anais do X Congresso Internacional Del CLAD sobre la reforma del Estado de la administracion pública. 2005 out. 18-21; Santiago, Chile. Santiago: [s.n.]; 2005.

Instituto Brasileiro de Geografia. Censo, 2006.

Irving S. Enfermagem psiquiátrica básica. Rio de Janeiro: Interamericana; 1979.

Kantorski LP, Souza J, Willrich JQ, Mielke FB. O cuidado em saúde mental: um olhar a partir de documentos e da observação participante. Rev Enferm UERJ. 2006;14(3):366-71.

Kirschbaum DIR. Análise histórica das práticas de enfermagem no campo da assistência psiquiátrica no Brasil, no período compreendido entre as décadas de 20 e 50 [tese]. Campinas: Faculdade de Enfermagem, Universidade Estadual de Campinas; 1994.

Kornblit A,Rascvsky A. Importância institucional de los llamados grupos de espera. Rev Argent Psiquiatr Psicolog Infanc Adolescencia. 1970;1(1):55560 .

Lefèvre F, Lefèvre AMC. $O$ discurso do sujeito coletivo: um novo enfoque em pesquisa qualitativa (Desdobramentos). Caxias do Sul: EDUCS; 2003.

Lima, LA, Fortes L, Lovisi G. O processo de reforma psiquiátrica brasileiro na era da globalização: desafios e perspectivas. Cadernos de Saúde Coletiva, Rio de Janeiro 2004.12(1):9-25. 
Lopez MEEF, Manzolli MC. Grupalidade em enfermagem psiquiátrica:algumas reflexões. In: Manzolli MC. Enfermagem psiquiátrica: da enfermagem psiquiátrica à saúde mental. Rio de Janeiro: Guanabara Koogan, 1996. p. 1-21.

Lopez MJM. Quando a voz e a palavra são atos terapêuticos; ação integração individual e coletiva nas palavras cotidianas do trabalho de enfermagem. In: Waldow VR. Maneiras de cuidar, maneiras de ensinar: a enfermagem entre a escola e a prática profissional. Porto Alegre: Artes Médicas; 1995. p. 153-88.

Luchese R. A enfermagem psiquiátrica e a saúde mental: necessária constituição de competências na formação e na prática do enfermeiro [tese]. São Paulo: Escola de Enfermagem, Universidade de São Paulo; 2005.

Machado AL, Colvero LA. O cuidado de enfermagem: o sujeito do cuidado como sujeito da relação. Revista Baiana de Enfermagem. 2003;18(1/2):51-5.

Machado AL, Colvero LA. O cuidado de enfermagem: olhando através da subjetividade. Rev Acta Paulista de Enfermagem, 1999,12(2):66-72.

Machado AL. Reforma psiquiátrica e mídia: representações sociais na Folha de S.Paulo. Rev Ciencias Saúde Coletiva. 2004;9(2):483-491.

Machado LD, Lavrador MCC. Loucura e subjetividade. In: Machado LD, Lavrador MCC, Barros ME, organizadores. Texturas da psicologia: subjetividade e política no contemporâneo. São Paulo: Casa do Psicólogo; 2001.

Maffesoli M. A conquista do presente. Natal: Argos; 2001.

Maffesoli M. A contemplação do mundo. Porto Alegre: Artes e Ofícios; 1995.

Maffesoli M. Elogio da razão sensível. Petrópolis: Vozes; 2005.

Maffesoli M. O tempo das tribos: o declínio do individualismo nas sociedades de massa. Rio de Janeiro: Forense Universitária, 1998.

Maffesoli, M. A subversão pós-moderna e o diabólico. Rev Famecos. 2006:143(107) 83-121. 
Maftum MA. O ensino de enfermagem em saúde mental e psiquiátrica no Paraná [tese]. Ribeirão Preto: Escola de Enfermagem, Universidade de São Paulo; 2004.

Magalhães MV. O Paraná e suas regiões nas décadas recentes: as migrações que também migram [tese]. Belo Horizonte: CEDEPLAR, Universidade Federal de Minas Gerais, 2003.

Medeiros TA. Formação do modelo assistencial no Brasil. Rio de Janeiro [dissertação]. Rio de Janeiro: Instituto de Psiquiatria, Universidade Federal do Rio de Janeiro; 1977.

Merhy EE, Amaral H. A reforma psiquiátrica no cotidiano II São Paulo: Hucitec; 2007.

Merhy EE. O conhecer militante do sujeito implicado: o desafio em reconhecê-lo como saber válido [Apresentado no I Curso de Difusão Cultural: Subjetividade no Cuidado em saúde na perspectiva da Enfermagem. Escola de Enfermagem USP. 10-11 e 17-18/2 2006.

Minayo C S. Pesquisa social: teoria, método e criatividade. Petrópolis: Vozes; 1994.

Minayo CS. O desafio do conhecimento: pesquisa qualitativa em saúde. São Paulo: Hucitec-Abrasco; 1997.

Minzoni MA. Assistência de enfermagem psiquiátrica [tese]. Ribeirão Preto: Escola de Enfermagem, Universidade de São Paulo; 1971.

Miranda CML. Internação psiquiátrica e reabilitação psicossocial. J Brás Psiquiat. 1998;47(9):437-9.

Miranda CML. O parentesco imaginário: história e representação social da loucura nas relações do espaço asilar. Rio de Janeiro: Editora da UFRJ; 1994.

Miranda FAN. Representações sociais sobre a atuação do enfermeiro psiquiátrico no cotidiano [tese]. Ribeirão Preto: Escola de Enfermagem da USP; 2002. 
Moraes AEC, Almeida Filho AJ. A trajetória da reforma psiquiátrica no Brasil: uma revisão bibliográfica. In: Anais do XIV Pesquisando em Enfermagem; 2007 mai. 16; Rio de Janeiro, BR. Rio de JAneiro: EEAN/ UFRJ; 2007.

Moreno V, Alencastre MB. Atendendo a família em casa: uma nova perspectiva para o cuidado de enfermagem. In: Anais do VII Encontro de Pesquisadores em Saúde Mental e VI Encontro de Especialistas em Enfermagem Psiquiátrica; 2002 mar. 25-28: Ribeirão Preto, BR. Ribeirão Preto: EERP; 2002. p.101.

Moreno V. Como desenvolver projetos de atenção à saúde mental no Programa da Saúde da Família [dissertação]. Ribeirão Preto: Escola de Enfermagem, Universidade de São Paulo, 1995.

Morin E. A educação e a complexidade do ser e do saber. Petrópolis: Vozes; 2006.

Nicácio MFS. O processo de transformação da saúde mental em Santos: desconstrução de saberes, instituições e cultura [dissertação]. São Paulo: Pontifícia Universidade Católica de São Paulo; 1995.

Oliveira AGB, Alessi NP. O trabalho de enfermagem em saúde mental: contradições e potencialidades atuais. Rev Latino-Am Enferm. 2003,11(3):333-40.

Oliveira FB, Fortunato ML. Saúde mental: reconstruindo saberes em enfermagem. Rev Bras Enferm. 2003;56(1):67-70.

Oliveira FB. Construindo saberes e práticas em saúde mental. João Pessoa: Universitária; 2002.

Organização Panamericana de Saúde//Organização Mundial de Saúde. Declaração de Caracas: Relatório final da I Conferência Regional para Reestruturação da Atencão Psiquiátrica. Caracas, nov.1990. [online]Disponível:WWW.saúde.gov.br/portal/saúde cidadão. Acessado 20 de janeiro 2008.

Ornellas CP. Paciente excluído: história e crítica das práticas médicas de confinamento. Rio de Janeiro: Revan; 1997. 
Paraná, Ministério Público do Estado. Saúde: uma população que não tem para onde ir. 2006 [on line]. Disponível:

www.procuradoriadoministeriopublico. Acesso 20 novembro 2006.

Peplau HE. Interpesonal relations in nursing. New York: G. P. Punam's; 1952.

Pereira MJB, Mishima SM. Revisitando a prática assistencial: a subjetividade como matéria para a reorganização do processo de trabalho na

enfermagem. Rev Interface-Comunicação, Saúde, Educ. 2003;7(12):83-100.

Pessini L. Humanização da dor e sofrimento no contexto hospitalar. Rev Bioetc. 2002;10(2):51-72.

Pichon RE. O processo grupal. São Paulo: Martins Fontes; 1988.

Pitta AMF, organizador. Reabilitação psicossocial no Brasil. São Paulo: Hucitec; 1996.

Pitta AMF, organizador. Tecendo uma teia de cuidados em saúde mental. In: Venâncio ATA, Cavalcanti MT, organizadores. Saúde mental - campo, saberes e discursos. Rio de Janeiro: IPUB/CUCA; 2001.

Pitta-Hoisel AM. Sobre uma política de saúde mental [dissertação]. São Paulo: Faculdade de Medicina, Universidade de São Paulo; 1984.

Prandoni RFS, Padilha MICS, Spricigo JS. A reforma psiquiátrica possível e situada. Rev UERJ. 2006;14(3):357-65.

Reco AR, Galera SAF. Qualidade de vida do familiar do portador de esquizofrenia: um estudo piloto aplicando a versão em português do instrumento abreviado de avaliação de Qualidade de vida "whoqol-bref". In: VIII Encontro de Pesquisadores em Saúde Mental e VII de Especialistas em Enfermagem Psiquiátrica; 2004 abr. 5-8; Ribeirão Preto, BR. Ribeirão Preto: EERP; 2004. p. 94.

Relatório final da I Conferência Nacional de Saúde; 1987 jun. 28-28; Brasília, BR. Brasília: Centro de Documentação do Ministério da Saúde; 1988.

Relatório final da II Conferência Nacional de Saúde; 1992; Brasília, BR. Brasília: Centro de Documentação do Ministério da Saúde; 1994. 
Relatório final da III Conferência Nacional de Saúde; 2001; Brasília, BR. Brasília: Centro de Documentação do Ministério da Saúde; 2001.

Ribeiro MC. A reabilitação psicossocial em um CAPS: concepção dos profissionais [dissertação]. São Paulo: Escola de Enfermagem, Universidade de São Paulo; 2005.

Ribeiro PRM. Saúde mental: dimensão histórica e campos de atuação. São Paulo: EPU; 1996.

Robertson, R. Globalization: social theory and global culture. Londres: Sage Publications; 1992.

Rocha RM. Enfermagem psiquiátrica: que papel é este? Rio de Janeiro: Instituto Franco Basaglia/Te Cora; 1994.

Rodrigues ARF. Relações interpessoais enfermeiro-paciente: análise teórica e prática com vistas à humanização da assistência em saúde mental [tese livre-docência]. Ribeirão Preto: Escola de Enfermagem, Universidade Paulista; 1993.

Roldão LL, Moreira R. Um jornalista na loucura, despertando loucos pelo jornalismo. In: Merhy EE, Amaral H, organizadores. A reforma psiquiátrica no cotidiano II. São Paulo: Hucitec; 2007.

Rolnick S. Uma insólita viajem à subjetividade: fronteiras com ética e a cultura. In: Lins D, organizador. Cultura e subjetividade - saberes nômades. Campinas: Papirus; 1997.

Santos BS. A globalização e as ciências sociais. São Paulo: Cortez; 2002.

Santos BS. Introdução de uma ciência pós-moderna. Rio de Janeiro: Graal; 1989.

Santos BS. Um discurso sobre as ciências. Porto: Afrontamento; 1996.

Santos MA, Silva G. Cuidando do cuidador: compreendendo os significados de conviver com um filho esquizofrênico. In: Anais do VII Encontro de Pesquisadores em Saúde Mental e VI Encontro de Especialistas em Enfermagem Psiquiátrica; 2002 mar. 25-28; Ribeirão Preto, BR. Ribeirão Preto: EERP; 2002. p. 100. 
Saraceno B. Libertando identidades: da reabilitação à cidade possível. Belo Horizonte: Te Cora; 2001.

Sartre JP. Critique de la raison dialectique: precede de questions de methode. Paris: S.L.Galjinard; 1960.

Secretaria de Saúde do Estado do Paraná, [citado 2008 jan. 27]. Disponível em: http://www.aenoticias.pr.gov/article.php?stryd=13322.

Silva ALA. Enfermagem em saúde mental: a ação e o trabalho de agentes de enfermagem de nível médio no campo psicossocial [tese]. São Paulo: Escola de Enfermagem, Universidade de São Paulo; 2003

Silva ATMC, Barros S; Oliveira MAF. Políticas de saúde e de saúde mental no Brasil: a exclusão/inclusão social como intenção e gesto. Rev Esc Enferm USP. 2002;36(1):4-9.

Silva Filho JF, Leibing, AG. A psiquiatria, sua história e seu futuro no Brasil. In: Albuquerque $\mathrm{P}$, Libério M. Práticas ampliadas em saúde mental: desafios e construções do cotidiano. Rio de Janeiro: IPUB/UFRJ; 1999.

Silva Júnior AG, Mascarenhas MT. Avaliação da atenção básica em saúde sob a ótica da integralidade: aspectos conceituais e metodológicos. In: Pinheiro R, Mattos R (Org.). Cuidado: as fronteiras da integralidade. Rio de Janeiro: CEPESC; UERJ, ABRASCO. 2005.

Silveira P. Narcisismo: sintoma social? Tempo social: Rev Social. USP. 1990:2(2):129-144.

Sklair L. Sociology of the global system. Baltimore: The Johns Hopkins University Press; 1991.

Souza M. Alencastre MB, Saeki T. Estudos sobre o ensino de enfermagem psiquiátrica e saúde mental no Brasil. São Paulo: Unijuí, 2000.

Souza MCBM. Ações de enfermagem no cenário do cotidiano de uma instituição psiquiátrica. Rev Latino-Am Enferm. 2003,11(5):678-84.

Spink MJP, Linguagem e produção dos sentidos no cotidiano. Porto Alegre: EDIPUCRS; 2004. 
Stefanelli MC. Relacionamento terapêutico enfermeira-paciente. Rev Esc Enferm. 1983; 17(1):39-45.

Sullivan HS. The interpessonal theory of psychiatry, New York: WW Norton \& Co; 1953.

Tatagiba MA, Filártiga V. Vivendo e aprendendo com grupos: uma meteodologia construtivista de dinâmica de grupo. Rio de Janeiro: DP\&A; 2001.

Telles EAB. O doente mental e a instituição psiquiátrica: a voz do silenciado. Rev Bras Enferm. 2002;55(1):13-8

Toledo VP. Sistematização da assistência de enfermagem psiquiátrica na reabilitação psicossocial [tese]. Ribeirão Preto: Escola de Enfermagem, Universidade de São Paulo; 2004.

Tonini NS. O planejamento em saúde mental no contexto da reforma psiquiátrica: um estudo dos municípios da região oeste do Paraná [tese]. Ribeirão Preto: Escola de Enfermagem, Universidade de São Paulo; 2005.

Torre EDHG, Amarante A. Protagonismo e subjetividade: a construção coletiva no campo da saúde mental. Rev Ciênc Saúde Col. 2001;6(1)1-17.

Travelbee J. Intervencion en enfermeria psiquiátrica: el processo de la relación de persona a persona. Washington: OPAS/OMS; 1979.

Vasquez AS. Entre a realidade e utopia: ensaios sobre política, moral e socialismo. Rio de Janeiro: Civilização Brasileira; 2001.

Vilela SC, Scatena MCM. A enfermagem e o cuidar na área de saúde mental. In: Anais do VII Encontro de Pesquisadores em Saúde Mental e VI Encontro de Especialistas em Enfermagem Psiquiátrica; 2002 mar. 25-28; Ribeirão Preto, BR. Ribeirão Preto: EERP; 2002. p. 198.

Waldow RV. Cuidar/cuidado: o domínio unificador da enfermagem. In: Waldow VR, Lopes MJ, Meyer DE. Maneiras de cuidar, maneiras de ensinar. Porto Alegre: Artes Médicas; 1995.

Who, Mental Healt-Organização Mundial de Saúde, 1987. 


\section{APÊNDICES}

\section{Apêndice A}

\section{INSTUMENTO PARA COLETA DE DADOS}

Pesquisa: A participação dos enfermeiros no processo da Reforma Psiquiátrica. Programa de Doutorado da Escola de Enfermagem da Universidade de São Paulo. Linha de Pesquisa: Processo de Cuidar no Campo Psiquiátrico e no Campo da Saúde Mental.

Pesquisadora: Terezinha Alves Dias

Orientadora: Dra Ana Lúcia Machado

Dados de identificação

Nome (iniciais ou pseudônimos)

Idade Sexo

Tempo de graduação

( ) <1 ano ( ) 2 a 4 anos ( ) 5 a 10 anos ( ) + de 10 anos

Tempo de atuação na área

( ) $<1$ ano ( ) 2 a 4 anos ( ) 5 a 10 anos ( ) + de 10 anos

\section{Questões Norteadoras}

1_Como você vê a Reforma Psiquiátrica? Fale sobre o que sabe e o que acha .........

2-Como é seu dia a dia no trabalho? Quais suas atividades?

3- Quais as dificuldades que você encontra no dia a dia do seu trabalho?

4- $O$ que acha que poderia facilitar seu dia a dia no trabalho? 


\section{Apêndice B}

ANEXOS

ANEXO A - TERMO DE CONSENTIMENTO LIVRE E ESCLARECIDO

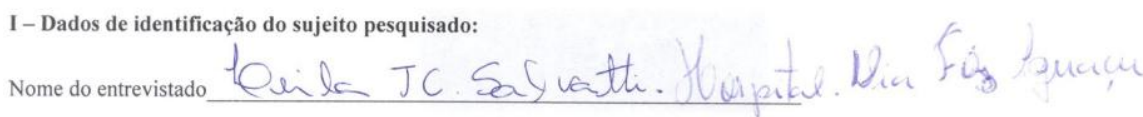

II - Dados sobre a pesquisa;Título da Pesquisa: A Participação dos Enfermeiros no Processo de Reforma Psiquiátrica

Pesquisadora: Terezinha Alves Dias (COREN Pr 54858) Doutoranda em Enfermagem Psiquiátrica da EEUSPSP Fone: (11)69097259 e-mail: teread@terra.com.br, Cascavel, (45) 32244519

III - Registro das explicações sobre a pesquisa ao participante Trata-se de um estudo vinculado ao Programa de Pós- Graduação da Escola de Enfermagem-USP, Doutorado de Enfermagem. Tem por objetivos: Descrever a prática cotidiana dos enfermeiros nos Serviços de Assistência de Saúde Mental da região oeste do estado do Paraná; Relacionar e analisar a prática destes enfermeiros com as propostas da Reforma Psiquiátrica. Para isto solicitamos que você responda algumas questões. Você é livre para expressar suas idéias. Você poderá fazer qualquer questionamento acerca do estudo e sobre a sua participação nele, se tiver alguma dúvida procurarei esclarecê-la em qualquer fase da pesquisa. A sua participação é voluntária, você não é obrigado (a) a participar do estudo. Você tem o direito de sair da pesquisa em qualquer etapa e em momento algum isto lhe trará prejuízos. Não haverá custos para você. As entrevistas serão realizadas em local data e horário combinados com você, garantindo a sua privacidade. Os dados da presente pesquisa serão registrados e gravados; posteriormente transcritos, lidos e analisados, mas o seu nome não constará dos registros. Sua identidade não será revelada nem mesmo na fase de conclusão e publicação do estudo. Todos os dados relativos ao estudo serão coletados e guardados em local seguro.

Antes da publicação dos resultados, você terá acesso ao material resultante de sua entrevista, em formato de narrativa, para validação ou retificações que considerar necessárias.

\section{IV - Consentimento Livre e Esclarecido:}

"Declaro que, após convenientemente esclarecido pelo pesquisador e ter entendido o que me fo explicado, consinto em participar da presente pesquisa".

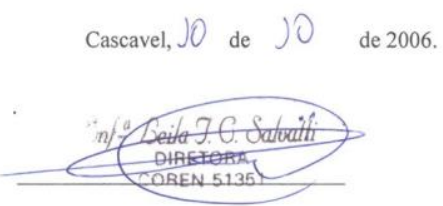

Assinatura do sujeito da pesquisa

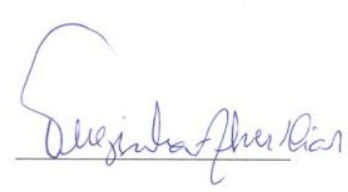

Assinatura do pesquisador 
ANEXOS

Anexo A

UNIVERSIDADE DE SÃO PAULO

ESCOLA DE ENFERMAGEM

Av. Dr. Enéas de Carvalho Aguiar, 419 - CEP 05403-000

II Fone.: 3066-7548 - Fax.: 280-8213

C.P. 41633 - CEP $05422-970$ - e-mail.: edipesq@usp.br

São Paulo, 09 de janeiro de 2006.

Ilm. ${ }^{\mathrm{a}} \mathrm{Sr} .^{\mathrm{a}}$

Terezinha Alves Dias

Ref.: Processo n ${ }^{\circ}$ 496/2005/CEP-EEUSP

Prezada Senhora,

Em atenção à solicitação referente à análise do projeto "A PARTICIPAÇÃO DOS ENFERMEIROS NO PROCESSO DE REFORMA PSIQUIÁTRICA”, informamos que o mesmo foi considerado aprovado pelo Comitê de Ética em Pesquisa da Escola de Enfermagem da Universidade de São Paulo (CEP/EEUSP).

Analisado sob o aspecto ético-legal, atende às exigências da Resolução $n^{\circ}$ 196/96 do Conselho Nacional de Saúde.

Esclarecemos que após o término da pesquisa, os resultados obtidos deverão ser encaminhados ao CEP/EEUSP, para serem anexados ao processo.

Atenciosamente,

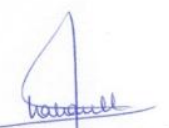

Prof. ${ }^{\text {a }}$ Dr. ${ }^{\text {a }}$ Dulce Maria Rosa Gualda

Coordenadora do Comitê de Ética em Pesquisa da

Escola de Enfermagem da Universidade de São Paulo 


\section{Anexo B}

\section{TERMO DE CONSENTIMENTO LIVRE E ESCLARECIDO}

I - Dados de identificação Nome do entrevistado: Secretaria Municipal de Saúde Mental

II - Dados sobre a pesquisa

Título da Pesquisa: A Participação dos Enfermeiros no Processo de Reforma Psiquiátrica

Pesquisadora: Terezinha Alves Dias (COREN Pr 54858) Doutoranda em Enfermagem Psiquiátrica da EEUSPSP Fone: (11) 69097259 e-mail: teread@terra.com.br, Cascavel, (45) 32244519 Telefone do Comitê de Ética em Pesquisa da EEUSP: (11) 3066-7548

III - Registro das explicações sobre a pesquisa ao participante

Trata-se de um estudo vinculado ao Programa de Pós-Graduação da Escola de Enfermagem-USP, Doutorado de Enfermagem. Tem por objetivos: Descrever a prática cotidiana dos enfermeiros nos Serviços de Assistência de Saúde Mental da região oeste do estado do Paraná; Relacionar e analisar a prática destes enfermeiros com as propostas da Reforma Psiquiátrica. Para isto solicitamos que você responda algumas questø̃es. Você é livre para expressar suas idéias. Você poderá fazer qualquer questionamento acerca do estudo e sobre a sua participação nele, se tiver alguma dúvida procurarei esclarecê-la em qualquer fase da pesquisa. A sua participação é voluntária, você não é obrigado (a) a participar do estudo. Você tem o direito de sair da pesquisa em qualquer etapa e em momento algum isto lhe trará prejuízos. Não haverá custos para você. As entrevistas serão realizadas em local data e horário combinados com você, garantindo a sua privacidade. Os dados da presente pesquisa serão registrados e gravados; posteriormente transcritos, lidos e analisados, mas o seu nome não constará dos registros. Sua identidade não será revelada nem mesmo na fase de conclusão e publicação do estudo. Todos os dados relativos ao estudo serão coletados e guardados em local seguro.

Antes da publicação dos resultados, você terá acesso ao material resultante de sua entrevista, em formato de narrativa, para validação ou retificaç̃̃es se considerar necessário.

IV - Consentimento Livre e Esclarecido:

"Declaro que, após convenientemente esclarecido pelo pesquisador e ter entendido o que me foi explicado, consinto em participar da presente pesquisa".

Cascavel, 16, agosto ,2006.

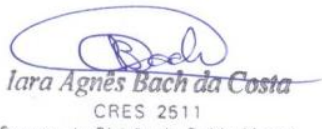

Assinatura do do sujeito da da pesquisa

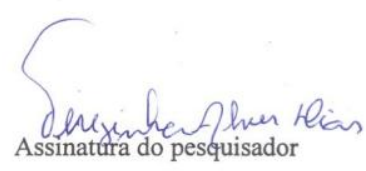

